\title{
ALPINIA (ZINGIBERACEAE): A PROPOSED NEW INFRAGENERIC CLASSIFICATION
}

\author{
R. M. SMITH
}

\begin{abstract}
K. Schumann's classification of Alpinia (Zingiberaceae), which subdivided the genus into five subgenera and 27 sections, was based, in the main, on the character of the secondary bracts (bracteoles). It is here proposed that the subgenera be reduced to two-Alpinia (7 sections and 10 subsections) and Dieramalpinia (4 sections and 2 subsections), and that the character of the labellum (petaloid or non-petaloid) be used as the main differentiating criterion. Such a classification shows the centre of distribution of subgen. Alpinia, in which the labellum is petaloid, to lie north of the equator; subgen. Dieramalpinia, in which the labellum is non-petaloid, or rarely so at the apex only, is now excluded from continental Asia and has its main concentration east of Wallace's line with its greatest number of species in New Guinea. Stigma types have been examined when possible and, so far, they substantiate the proposed classification.

Keys to the subgenera, sections and subsections, together with distribution maps are provided. In Appendix 1 all published names in Alpinia are listed and annotated. Appendix 2 gives a key to the terminally-flowered genera of subfamily Alpineae; this is followed by five new names and six new combinations in Alpinia while A.cordylinoides is transferred to Riedelia.
\end{abstract}

\section{INTRODUCTION}

The existing classification of Alpinia is almost entirely that of K. Schumann (1904) with later small additions, mainly at sectional and subsectional level, by Valeton $(1913,1914)$ and Loesener (1930). Holttum (1950), dealing with species occurring in the Malay Peninsula only, divided Alpinia into four genera; Cenolophon, Alpinia, Catimbium and Languas. The two latter names are illegitimate when used at generic level in the sense of Holttum (Burtt \& Smith, 1972). Some reduction in the number of sections has been effected by Burtt \& Smith (1972) and Smith (1978). Schumann's classification divided the genus into five subgenera (see Map 1, p. 66) and 27 sections, and was primarily based on the character of the bracts and, more particularly, the bracteoles (secondary bracts). Subgenera Alpinia (seven sections), Probolocalyx, and Catimbium (two sections) comprised species with or without bracts; bracteoles, when present, are open to the base. Subgenus Dieramalpinia (12 sections) covered all species with tubular bracteoles. The remaining subgenus Rhizalpinia contained species said to produce radical inflorescences; most of these have been transferred to other genera. The infrageneric structure now proposed gives emphasis to the form of the labellum.

\section{MATERIALS}

It should be made clear that, in many instances, type collections have not been seen. This is particularly true of the numerous species recently described from China, several of which have no full description in Latin, and English translations from the Chinese 

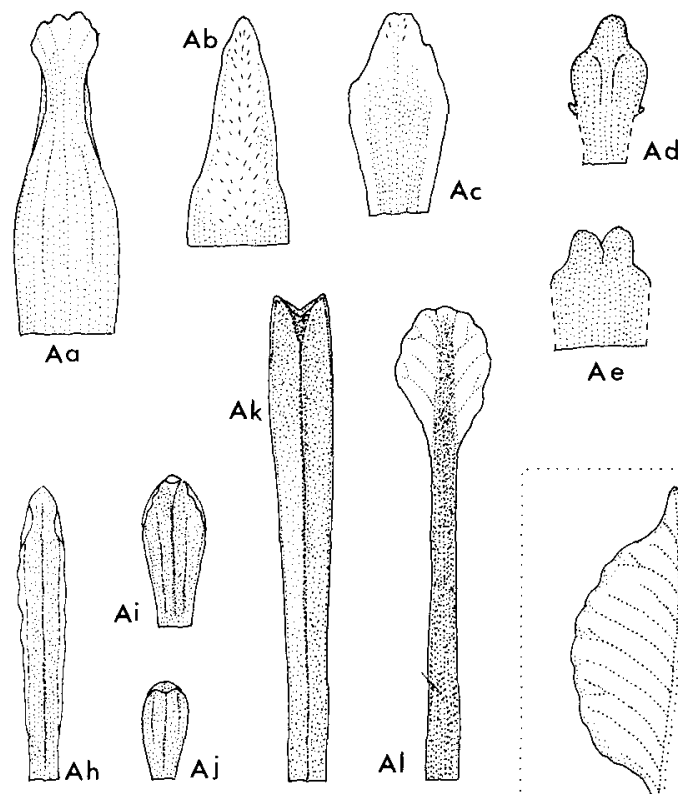
Ad
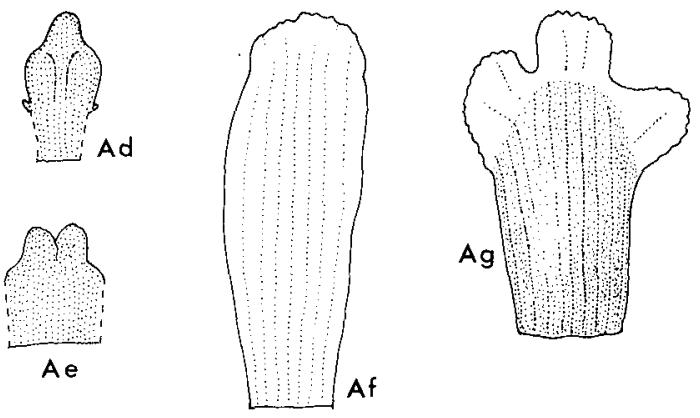

A

Al
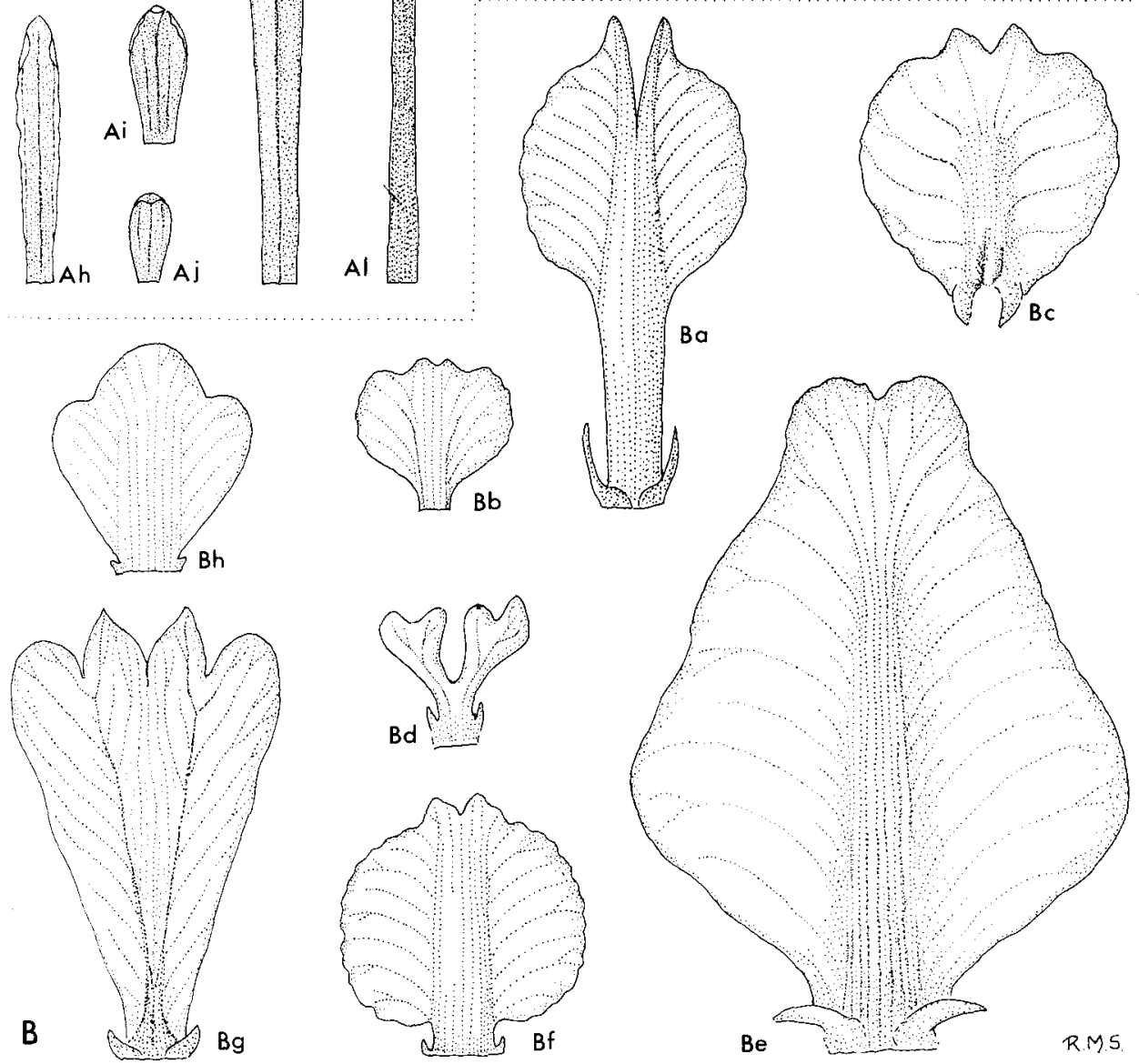

Fig. 1. Labellum types in Alpinia. A, subgenus Dieramalpinia: a-c, sect. Dieramalpinia: a, A. oceanica; b, A. domatifera; c, A. carinata; d, e, sect. Eubractea: d, A. eubractea; e, A. beamanii; f, g, sect. Myriocrater: f, A. laxisecunda; g, A. monopleura; h-l, sect. Pycnanthus: h, A. inaequalis; i, A. samoensis; j, A. hemsleyana; k, A. singulifiora; l, A. macrocephala. B, subgenus Alpinia: a-d, sect. Alpinia: a, A. galanga (subsect. Alpinia); b, A. chinensis (subsect. Alpinia); c, A. nieuwenhuizii (subsect. Paniculatae); d, A. rosea (subsect. Presleia); e, A. calcarata (subsect. Catimbium). B: f-h, sect. Allughas: f, A. caerulea (subsect. Caerulea); g, A. nigra (subsect. Allughas); h, A. murdochii (subsect. Allughas). All $\times 2$. 
are not yet to hand. The many species described from Taiwan by Hayata $(1915,1920)$ have also proved problematic; here I have followed, in the main, the synonymy of the recent Flora Reipublicae Popularis Sinicae 16 (1981). Elmer's Philippine species, often described from fruiting material, have proved particularly difficult to elucidate, and several have merely been listed (Appendix 1) as imperfectly known species.

The destruction of the types of Schlechter and others at Berlin, upon which so many species from New Guinea are based, is less troublesome. The descriptions of Valeton, always excellent and frequently well illustrated, and to a lesser extent those of Schumann, usually allow a decision on the sectional position of a species to be made with certainty.

Unquestionably, some species will have been incorrectly placed in the following account; the names of those to which serious doubt is attached are preceded by an interrogation mark.

\section{New Classification and Characters}

It is proposed that Alpinia be subdivided into two subgenera, namely Alpinia and Dieramalpinia. It has long been recognized that subgenus Probolocalyx does not form a homogeneous group; Valeton (1913) correctly transferred two species to Riedelia, the remainder are here assigned to four different subsections of subgenus Alpinia. Catimbium is retained but reduced to subsectional rank.

Major subdivision of Alpinia based on the character of the bracteole while undeniably useful at sectional level (in the present treatment only in sect. Kolowratia are species with open bracteoles and species with tubular bracteoles placed together) is less than satisfactory since it separates taxa with very similar flower types. For example, the showy petaloid lips of $A$, argentea and $A$. glabra, neither of which have tubular bracteoles, closely resemble those of $A$. rafflesiana and $A$. pahangensis, species hitherto placed in subgen. Dieramalpinia but here assigned to subgen. Alpinia. Study of labellum form and, as will be shown below, that of the stigma, indicates that these organs may provide a sounder basis for subdivision and this is to some degree justified geographically (Map 2).

\section{L_ABELLUM}

Broadly speaking the labellum (Fig. 1) in Alpinia falls into two categories:

1. Subgenus Alpinia. Labellum usually concave often with incurved margins, sometimes held flat or pendulous, commonly striped or spotted, the margins extending into a petaloid area with divergent venation (except in $A$. denticulata); rarely the venation parallel throughout.

2. Subgenus Dieramalpinia. Labellum always held erect, almost always closely pressed against the stamen, usually unstriped and without spots, the lateral margins not well developed, the apex occasionally expanding into a small petaloid area. 


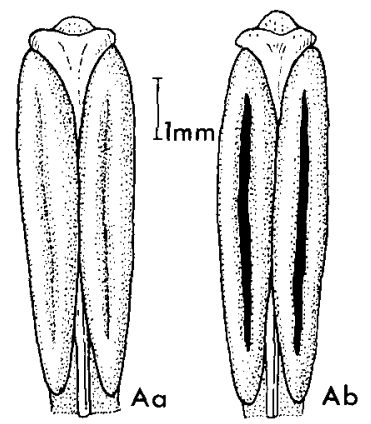

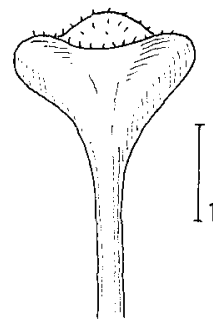

Ac

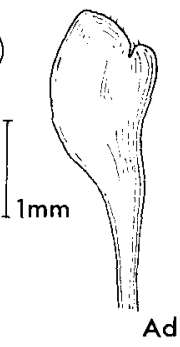

A

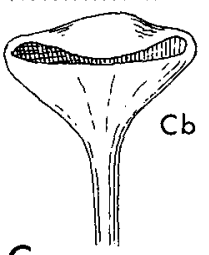

$\mathrm{C}$

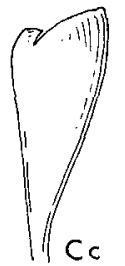

$\mathrm{Cc}$
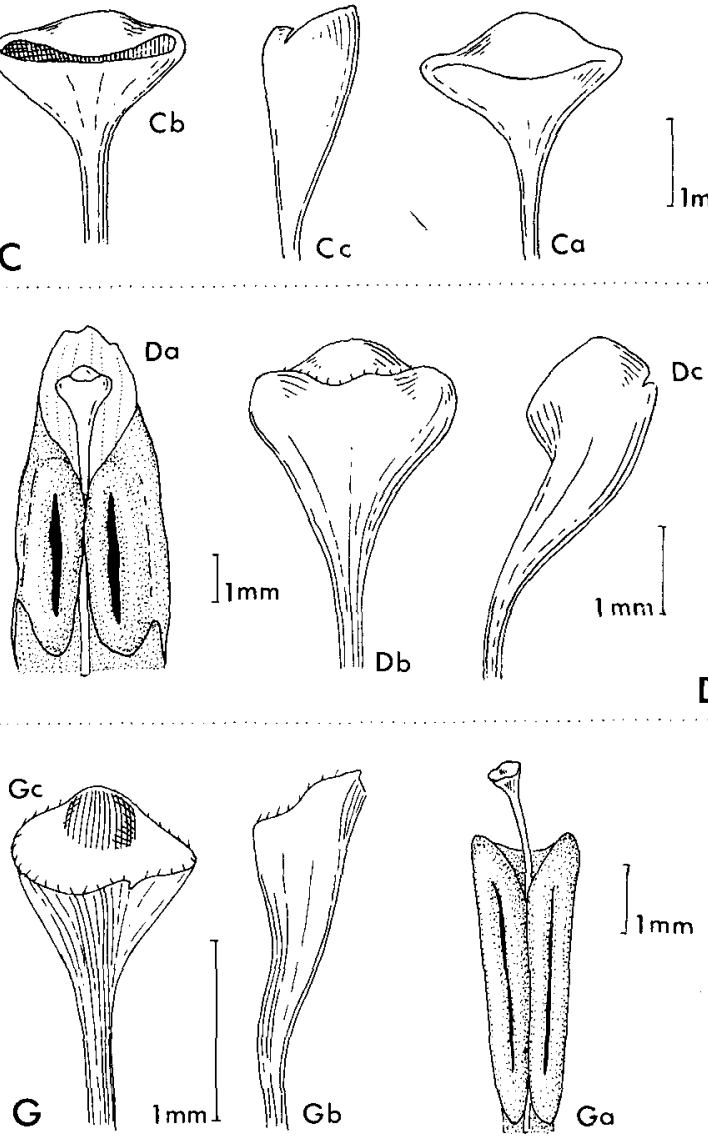

D

Fig. 2. Stigmas and anthers in subgen. Dieramalpinia. A, A. oceanica (sect. Dieramalpinia): Aa, from an unopened flower; Ab, after anthesis; Ac, stigma; Ad, stigma, lateral view. B, A. kiungensis (sect. Dieramalpinia): Ba, stigma; $\mathrm{Bb}$, stigma, lateral view. C, A. carolinensis (sect. Dieramalpinia): $\mathrm{Ca}$, stigma before anthesis; $\mathrm{Cb}$, stigma after anthesis; Cc, stigma, lateral view. D, A. laxisecunda (sect. Myriocrater): Da, stigma; Db, stigma, lateral view. E, A. pulchra (sect. Pycnanthus): Ea, at anthesis; Eb, lateral view; Ec, stigma from old flower. F, A. boia (sect. Pycnanthus): Fa, at anthesis; Fb, stigma; Fc, stigma, lateral view. $\mathrm{G}$, A. eubractea (sect. Eubractea): Ga, after anthesis; Gb, stigma, lateral view; Gc, stigma. A from living material; B, C, D, E, G from spirit material; F from dried material. 


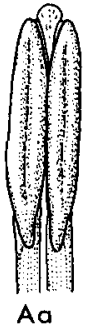

A
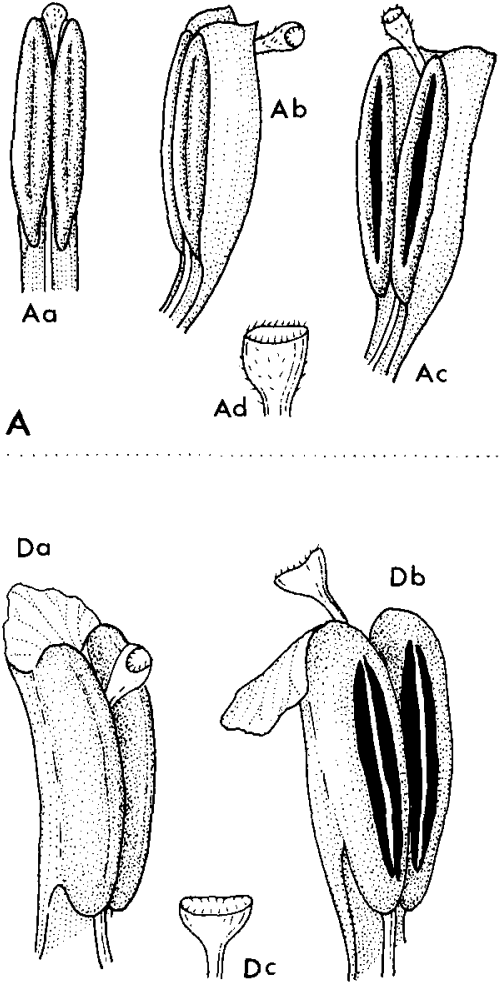

D
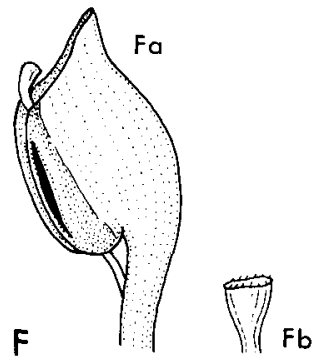

$\mathbf{G}$

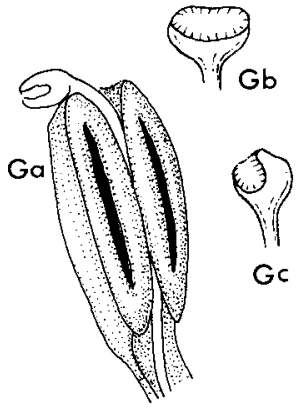

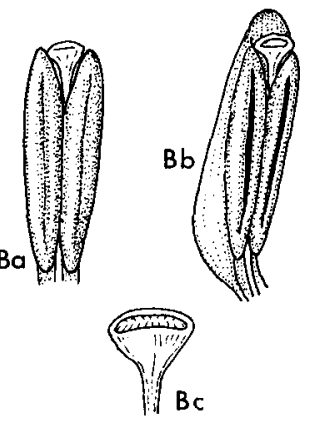

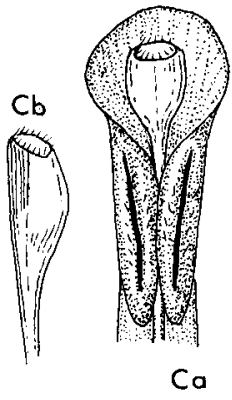

B
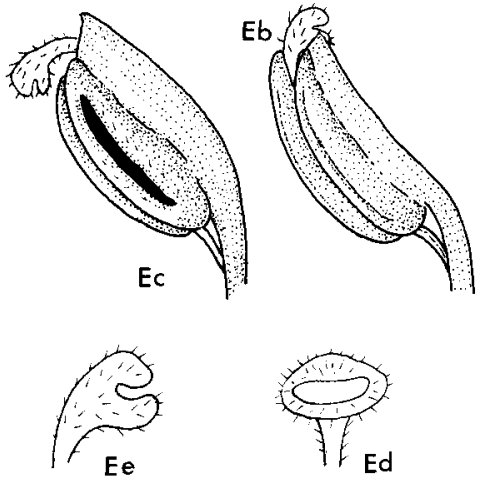

Ea

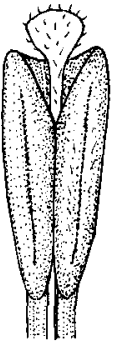

$E$
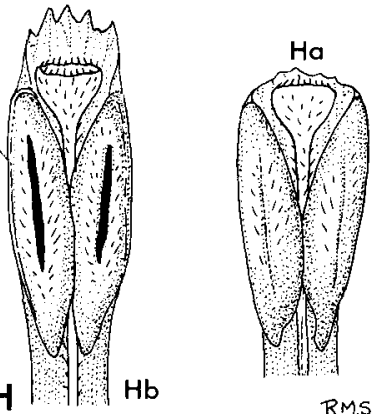

RM.S

Fig. 3. Anthers and stigmas in Alpinia subgen. Alpinia. A, A. galanga (sect. Alpinia subsect. Alpinia): Aa, from an unopened flower; $\mathrm{Ab}$, just before anthesis, stigma strongly recurved; Ac, after anthesis, stigma curving forwards; Ad, stigma. B, A. pubiflora (sect. Alpinia subsect. Presleia): Ba, from an unopened flower; $\mathrm{Bb}$, after anthesis; $\mathrm{Bc}$, stigma. C, A purpurata (sect. Guillainia): $\mathrm{Ca}$, after anthesis; $\mathrm{Cb}$, stigma, lateral view. D, A. glabra (sect. Alpinia subsect. Probolocalyx): Da, before anthesis; Db, after anthesis, anther crest becoming reflexed. E, A. zerumbet (sect. Alpinia subsect. Catimbium): Ea, from an unopened flower; Eb, just before anthesis; Ec, after anthesis; Ed, stigma, from above; Ee, stigma, lateral view. F, A. nieuwenhuizii (sect. Alpinia subsect. Paniculatae): Fa, after anthesis; Fb, stigma. G, A. abundiflora (sect. Fax): Ga, after anthesis; Gb, stigma, lateral view. H, $A$. argentea (sect. Alpinia subsect. Cenolophon): Ha, from an unopened flower; $\mathrm{Hb}$, after anthesis. A, E from living material, the remainder from spirit collections. Anthers $\times 4$. Stigmas much enlarged. 
The adoption of the labellum type as the major criterion for the division of Alpinia dictates the transfer of some 17 species hitherto placed in subgenus Dieramalpinia to subgenus Alpinia.

\section{STIGMA}

With the exception of Valeton $(1913,1914)$, and he only to a small extent, virtually no one has paid attention to the morphology of the stigma (Figs 2,3) in Alpinia (or indeed to the stigmas of most genera throughout the Zingiberaceae sensu stricto). In fact, comments on indumentum apart, they are rarely described at all. There are, however, indications that differing stigma types occur and that these may strengthen the case for a new classification of Alpinia. The following observations are perhaps premature in that only a small number of species have been studied from ideal material, i.e. fresh or in spirit, and with flowers at different stages of development.

Subgenus Alpinia (Fig. 3). In all but sections Arctiflora and Fax, the stigma is generally (but not always) well expanded with a more or less terminal, rounded to elliptic, frequently ciliate opening. It may occasionally be funnel-shaped, and is strongly so in sect. Kolowratia. More usually the rim is more or less thickened. In the young stage the style often curves over the anther so that the stigma projects behind the thecae, e.g. A. galanga; this has not been observed in subgen. Dieramalpinia. In sect. Fax the orifice is probably ventrally placed. The monotypic sect. Arctiflora deviates, with a stigma-type approaching that of sect. Pycnanthus.

Subgenus Dieramalpinia (Fig. 2). In sect. Pycnanthus the stigma is commonly erect and clavate with a usually rounded orifice (which is clearly visible in the young bud) placed subapically or, more often, on the ventral face. In a few species it is geniculate with a small orifice at the tip. In the species examined in sect. Dieramalpinia, and sect. Myriocrater, many of them from dried material only, the stigma is much more rigid, gradually becoming well expanded and always erect, more or less obconical and flattened on the ventral face. On the same plane there is a narrowly elliptic opening which is only visible on the old flower; in bud, or even at anthesis, this opening is quite closed. Stigmas of this type have not been observed in subgen. Alpinia. The small sect. Eubractea may represent a further stigma type within subgen. Dieramalpinia, possibly funnel-shaped; but additional material is essential to verify this.

\section{MONOECISM}

It has been shown (Burtt \& Smith, 1972; Smith, 1977, 1989) that in two sections of subgen. Dieramalpinia, namely sections Myriocrater and Eubractea, the lowermost flowers on the cincinnus are hermaphrodite, the remainder are functionally male. In sect. Myriocrater (Fig. 8D) it is the first (rarely the second) flower that is hermaphrodite. In sect. Eubractea (Fig. 8B) the situation appears to be different in that more or less half the flowers in a cincinnus (the lower half) produce fruit. Monoecism has not yet been observed in sect. Dieramalpinia (Fig. 9) but many of its species are badly known. Sex forms appear to be quite absent from the otherwise very distinctand much better known-sect. Pycnanthus (Fig. 8A, C). There are no records of monoecism in subgen. Alpinia. 


\section{GENERIC LIMITS}

Any attempt to reclassify Alpinia should at least make reference to the terminallyflowered genera of the tribe Alpineae that are nowadays generally accepted. Reasons for the acceptance of Psychanthus Ridley are given elsewhere (Edinb. J. Bot. 47: 77, 1990). Setting aside the neotropic and African Renealmia, which is cytologically distinct, these genera are restricted to Asia. Pommereschea Wittmack, Stadiochilus R. M. Smith and Rhynchanthus Hook. f. are clearly defined, and may be misplaced in the tribe Alpineae (Smith, 1980). All occur in Burma, although Rhynchanthus is also known in China. The remaining five genera have a more southerly distribution. Burbidgea Hook. f. comprises five species native to Borneo, and is distinctive in the uniformly yellow/orange flowers which are sometimes pink initially and in the inconspicuous narrow labellum. The monotypic Vanoverbergia Merr. (Philippines) is a curious plant which Merrill considered to be intermediate between Alpinia and Riedelia. The lateral petals are united to the lower part of the labellum for a third to half of their length and the free part of the lip divided into two linear lobes. The filament is described as 'channelled on the inside and inclosing the style'. The isotype material $(\mathrm{K})$ is poor. Riedelia $\mathrm{D}$. Oliver, a large genus of c.60 species, occurs in New Guinea, the Bismarck Archipelago and the Moluccas. It is separable from Alpinia by the deciduous calyx and is badly in need of revision. Plagiostachys (Indonesia, Malaysia and the Philippines) still requires much elucidation. It is characterized by the apparently lateral, tightly congested inflorescence, which is, in fact, terminal on the short stem of the leafy-shoot, and breaks through the leaf sheaths usually just above ground level. The inflorescence is, in many species, very mucilaginous and in herbarium material it is often impossible to distinguish its structure accurately. However, as far as is known, the Plagiostachys inflorescence is not dissimilar to some found in Alpinia; the bracteoles are usually tubular, each subtending a single flower, and the labellum, although small and rather fleshy, is petaloid with divergent venation. Laterally produced inflorescences are not unknown in Alpinia (A. havilandii, A. hansenii for example) but are pushed out from the leaf sheath near the top of the longstemmed leafy-shoot and are, as far as is known, never mucilaginous.

Following Ridley (1909) and Merrill (1922), Leptosolena Presl, which Schumann reduced to sectional level within Alpinia, is treated as a separate genus. Leptosolena is a monotypic Philippine endemic, well differentiated from Alpinia by the large flowers (to $12 \mathrm{~cm}$ long), with very slender corolla tubes which are exserted from the calyx for more than half their length.

A key to the terminally-flowered genera of tribe Alpineae is included (Appendix 2).

A good case might be made for raising sect. Pycnanthus to generic level, also the Philippine endemic Kolowratia, but the prime aim of the present work is to suggest new lines for future research and the ranks accorded to the various 'groups' is a secondary consideration. No apology is made for the reduction of subgenus Catimbium and sect. Cenolophon to subsectional rank; the dividing line between the two is not clear cut. A. havilandii for example, here placed in subsect. Cenolophon, is a single- 
flowered species with minute bracts which are rarely seen in the herbarium, but in the large, showy labellum it resembles subsect. Catimbium.

Two genera described by Ridley have had to be dealt with. Eriolopha (1916) is confined to the mainland of New Guinea and most of its species have already been transferred to Alpinia by Loesener (1930). One of its members belongs to sect. Pycnanthus, and the remainder, including the type species (E. flagellaris Ridley), are placed in sect. Dieramalpinia. Adelmeria (1909), which is confined to the Philippines, is poorly known, as are many Zingiberaceae from these islands whence few good modern collections have come. They are here placed, tentatively, in sect. Dieramalpinia.

\section{DISTRIBUTION}

With the exception of Fiji and Samoa, subgen. Alpinia, as here defined, occurs throughout the entire geographical range of the genus, but its centre of distribution lies well to the north of the equator. Mainland Asia, plus Japan, Taiwan, Hainan, Sri Lanka and the Andamans account for approximately 70 species and subgen. Dieramalpinia is not represented in this area. In Borneo, Sumatra, Java and the Philippines we find over 50 species of Alpinia, only nine of them in subgen. Dieramalpinia, but in Sulawesi the subgenera are evenly divided, each with seven species. In New Guinea and the surrounding islands, including the Moluccas, subgen. Dieramalpinia dominates with over 60 species while there are only seven in subgen. Alpinia. Australia provides the exception to this pattern, the five species recorded from that continent all belong to subgen. Alpinia.

\section{TAXONOMIC REVISION}

Alpinia Roxb. in Asiat. Res. 11: 350 (1810)—nom. cons.; K. Schum. in Bot. Jahrb. 27: 270 (1899) \& Pflanzenr. Zing. 308 (1904).

Syn.: Heritiera Retz., Obs. Bot. 6: 17 (1791) - non Aiton (1798). Type:

H. allughas Retz. = Alpinia nigra (Gärtner) B. L. Burtt.

Albina Giseke, Prael. Ord. Nat. 207, 227, 248 (1792). Lectotype

(selected here): $A$. alba Giseke = Alpinia galanga (L.) Sw.

Buekia Giseke, op. cit. 204, 216, 239. Type: Costus malaccensis

König = ? Alpinia javanica Bl.

Martensia Giseke, op. cit. 207, 229, 249-non Martensia Hering ( 1841 , nom. cons.). Type: $M$. aquatica Giseke = Alpinia aquatica (Retz.) Roscoe.

Hellenia Willd., Sp. Pl. 1: 4 (1791)-non Hellenia Retz. (1791). Type: $H$. allughas Willd. = Alpinia nigra (Gärtner) B. L. Burtt. Zerumbet Wendl., Sert. Hannov. 4: 3 (1798). Type: Zerumbet speciosum Wendl. = Alpinia zerumbet (Pers.) Burtt \& Smith. 
Catimbium Lestib. in Ann. Sc. Nat. 2 sér. 15: 341 (1841) —non Catimbium Juss. (1798). Type: Alpinia zerumbet (Pers.) Burtt \& Smith (1972: 205).

Cenolophon Bl., Enum. Pl. Jav. 81 (1827). Type: C. rubrum Bl. $=$ Alpinia rubricaulis $\mathrm{K}$. Schum.

Kolowratia Presl, Reliq. Haenk. 1: 113 (1827). Type: K. elegans Presl = Alpinia elegans (Presl) K. Schum.

Strobidia Miq., Fl. Ind. Bat. Suppl. 614 (1860). Type: Strobidia sumatrana Miq. = Alpinia sumatrana (Miq.) K. Schum.

Guillainia Vieill. in Bull. Soc. Bot. Normand. 10: 92 (1866). Type: G. purpurata Vieill. = Alpinia purpurata (Vieill.) K. Schum.

Hellwigia Warb. in Bot. Jahrb. 13: 279, 451 (1891). Type: Hellwigia pulchra Warb. = Alpinia pulchra (Warb.) K. Schum.

Elmeria Ridley in Elmer, Lflts Phil. Bot. 2: 569 (1909)—non Elmera Rydb. (1905). Type: E. bifida Ridley = Alpinia paradoxa (Ridley) Merr.

Adelmeria Ridley in Elmer, op. cit. 603. Type as above.

Languas J. K. Small, Fl. SEUS, ed. 2, 307 (1913). Type: Languas speciosa (Wendl.) Small = Alpinia zerumbet (Pers.) Burtt \& Smith.

Eriolopha Ridley in Hooker's Icon. Pl. 31: t.3067 (1916). Type: Eriolopha flagellaris Ridley = Alpinia flagellaris (Ridley) Loesen.

Type species: A. galanga (L.) Sw., Obs. Bot. 6 (1791). Type: No specimen at LINN.

Herbs up to $12 \mathrm{~m}$ tall, more usually $2-4 \mathrm{~m}$; leafy shoots many-bladed and frondlike, rarely with 1-4 blades. Inflorescence, almost without exception, terminal on the leafy-shoot, tightly congested or lax, sometimes branched. Bracts, when present, open to the base, rarely calyptrate, each subtending a single flower or a cincinnus of twomany flowers. Bracteoles open to the base or tubular, rarely calyptrate, sometimes absent. Calyx usually tubular, sometimes unilaterally split, occasionally to the base; corolla-tube often more or less equal to or shorter than the calyx, more rarely exserted from it, the dorsal lobe more or less hooded, sometimes markedly so, generally wider than the lateral lobes; labellum often petaloid and showy, sometimes inconspicuous and much thickened, variously lobed or entire; lateral staminodes small or absent; anther sessile or with a well-developed filament, connective crested or not; stigma usually well-expanded, sometimes clavate, rarely geniculate; epigynous glands rarely free from each other, often massive; ovary usually trilocular with axile placentation, rarely unilocular with parietal placentation. Capsule commonly spherical, more rarely ellipsoid to flask-shaped; seed arillate, often angular.

Distribution: Japan, China, Indo-China, Burma, India, the Andamans, Sri Lanka, Thailand, Malaysia, the Philippines, Carolines, Indonesia, New Guinea, Australia, the Solomons, New Hebrides, New Caledonia, Fiji and Samoa. 


\section{The SubGenera}

Subgenus Alpinia.

Syn.: Heritiera Retz.

Albina Giseke

Buekia Giseke

Martensia Giseke

Zerumbet Wendl.

Catimbium Lestib.

Cenolophon B1.

Kolowratia Pres1

Strobidia Miq.

Guillainia Vieill.

Languas J. K. Small

Labellum usually concave with incurved margins, sometimes flat or pendulous, commonly fleshy centrally, sometimes unguiculate, the margins of the limb expanded into a usually thin textured petaloid area with divergent venation (except in $A$. denticulatum), rarely the venation parallel throughout. Stigma barely to well expanded, the orifice elliptic to rounded, \pm terminal, occasionally distinctly funnel-shaped, often held behind the anther before anthesis. Bracts, when present, rarely persistent; bracteoles open to the base or tubular, rarely calyptrate, occasionally absent. Flowers borne singly or in cincinni. Plants, as far as is known, never monoecious.

Type species: $A$. galanga (L.) Sw.

Distribution: As for the genus excluding Fiji and Samoa. Map 2.

Subgenus Dieramalpinia (K. Schum.) K. Schum., Pflanzenr. Zing. 343 (1904).

Syn.: Hellenia Willd.

Hellwigia Warb.

Elmeria Ridley

Adelmeria Ridley

Eriolopha Ridley

Labellum held erect and close to the stamen, usually fleshy, the lateral margins not expanded, the apical part sometimes extending into a small petaloid area with divergent venation. Stigma often well expanded, rigid, \pm obconical with an elliptic orifice on the ventral face or clavate with a \pm rounded orifice or geniculate, rarely funnelshaped. Flowers, except in some species of sect. Pycnanthus, in cincinni. Bracts often large, usually persistent; bracteoles always tubular, often tightly clasping. Plants sometimes monoecious.

Lectotype species (selected here): $A$. oceanica Burkill.

$A$. oceanica is a well-known species, currently in cultivation. Its distribution ranges from the Manus Is. south and east to the New Hebrides; it has not been recorded from the New Guinea mainland. 
Distribution: the Philippines, Carolines, Borneo, Sulawesi, the Moluccas, New Guinea and the Bismarck Archipelago, the Solomons to Fiji and Samoa.

\section{Key to the Sections of Subgenus Alpinia}

1. Leafy-shoots not frond-like; blades $1-4$ Didymanthus

- Leafy-shoots frond-like; many-bladed 2

2. Calyx spathe-like, coriaceous, splitting to the base at anthesis; corolla tube exserted from the base of the calyx and held more or less at right angles to it; stigma large, funnel-shaped (the Philippines) Kolowratia

- Calyx not as above, if splitting to the base then membranous; corolla tube usually straight, occasionally curved; stigma funnel-shaped or not, sometimes barely expanded 3

3. Bracteoles absent or, if present, open to the base (occasionally joined in the young stage or, rarely, calyptrate); flowers single or in cincinni Alpinia

- Bracteoles always present, always tubular, often persistent (rarely, in A. abundiflora, open to the base and tubular in the same cincinnus); flowers always in cincinni

4. Inflorescence surrounded by an involucre of sterile bracts, sometimes radical Fax

- Inflorescence lacking sterile bracts, always terminal 5

5. Bracts large, showy, concealing all but the upper part of the flower; corolla tube slender, well exserted from the calyx; pedicels short

Guillainia

- Bracts sometimes conspicuous but never concealing the flowers; corolla tube equal to or slightly longer than the calyx; pedicels usually at least $2 \mathrm{~cm}$ long

6. Bracteoles narrowly cylindric; anther sessile,thecae \pm divaricate (Australia) Arctiflorae

- Bracteoles cup to funnel-shaped; filament well formed; thecae \pm parallel

Allughas

Sect. Didymanthus K. Schum., Pflanzenr. Zing. 366 (1904).

Short stemmed or almost stemless; leaves 1-4. Bracts oblong, ebracteolate. Flowers in cincinni of $2-4$, calyx not unilaterally split; labellum entire or bilobed at the apex; lateral staminodes subulate points; anther \pm ecristate; stigma slightly expanded with a ciliate orifice; epigynous glands free from each other. Capsule ellipsoid (at least in A. psilogyna).

Type species: $A$. pumila Hook. f. in Bot. Mag. 111: t.6832 (1885). Fig. 6A.

Other species: A. psilogyna D. Fang.

Distribution: China. Map 4. 


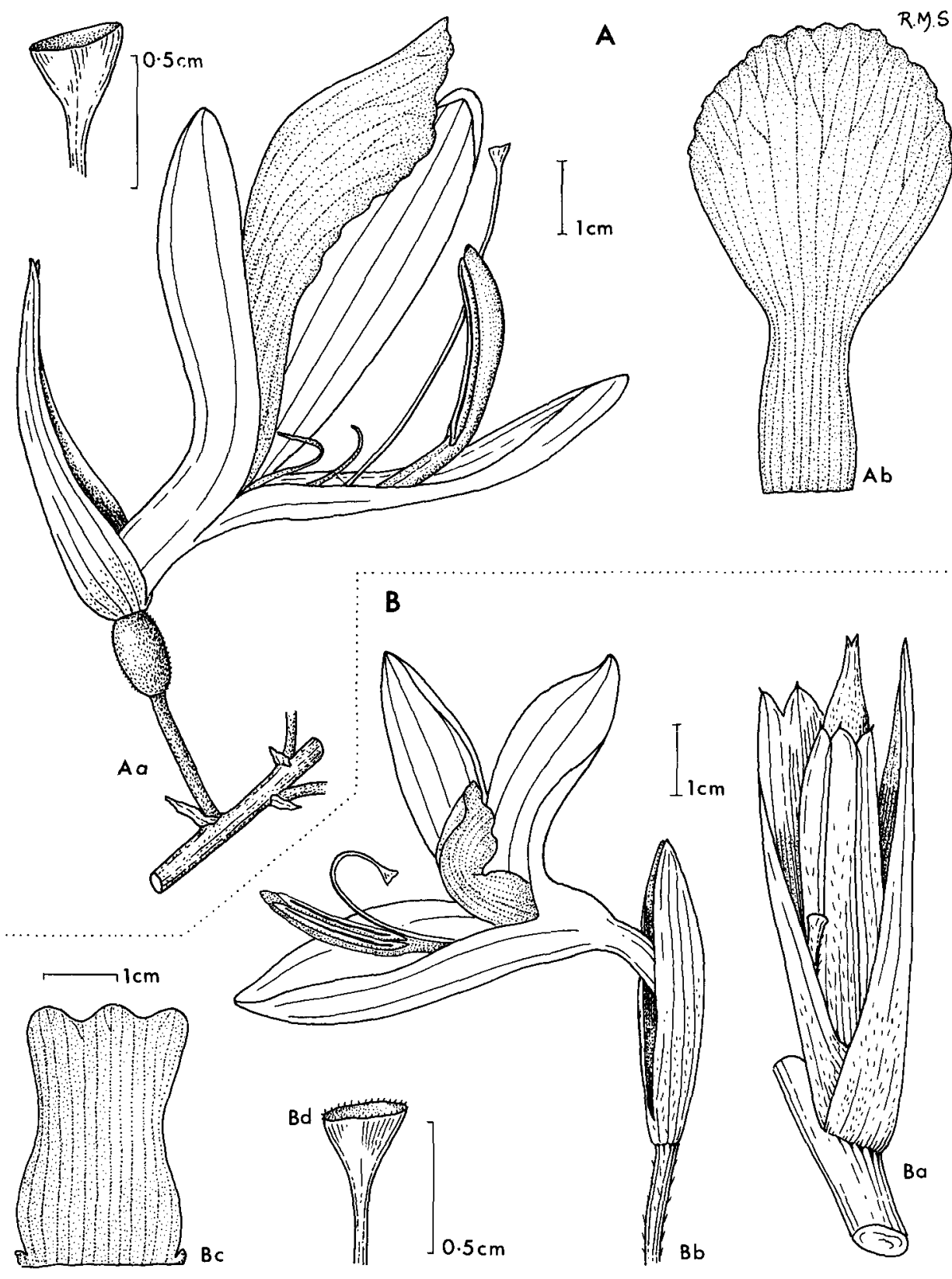

FIG. 4. Alpinia subgen. Alpinia sect. Kolowratia. A, A. vanoverbergii: Aa, part of main axis and single flower; Ab, labellum; Ac, stigma. B, A. elegans: $\mathrm{Ba}$, part of main axis and cincinnus; $\mathrm{Bb}$, flower; $\mathrm{Bc}$, labellum; Bd, stigma. A, from dried material, B from spirit material. 
Hooker had some misgiving in placing what he considered to be a plant with a radical inflorescence in Alpinia. In fact, the inflorescence of $A$. pumila arises from the leaf sheaths, exactly as in Boesenbergia (tribe Hedychieae), and is terminal on the very short stem. The few-leaved shoots of sect. Didymanthus are unique in Alpinia.

Sect. Kolowratia (Presl) Loesener, Pflanzenfam. ed. 2, 15a: 621 (1930).

Syn.: Kolowratia Presl, Reliq. Haenk. 1: 113, t.20 (1827). Type: $K$. elegans Presl.

Alpinia sect. Eubractea K. Schum. subsect. Kolowratia (Presl) Val. in Nova Guinea (Botanique) 8: 943, 947 (1913) - p.p. incl. type: Alpinia elegans (Presl) K. Schum.

Alpinia sect. Kolowratia (Presl) Loesener subsect. Eukolowratia Loesner, Pflanzenfam. ed. 2, 15a: 622 (1930)-p.p. incl. type. [Alpinia sect. Dieramalpinia K. Schum. in Bot. Jahrb. 27: 272, $286(1899)$ - p.p. excl. type.]

[Alpinia sect. Eubractea K. Schum., Pflanzenr. Zing. 352 (1904)—p.p. excl. type.]

Inflorescence pendulous (or erect?), unbranched. Bracts large and persistent or small and caducous; bracteoles tubular or non-tubular. Flowers single or in cincinni; calyx \pm coriaceous, splitting to the base as the flower opens, the corolla tube exserted from the base of the calyx and held more or less at right angles to it; labellum obovate or rectangular, venation entirely parallel or divergent in the upper half; lateral staminodes present; filament well formed; anther with a small crest; stigma funnel-shaped; epigynous glands massive. Capsule, as far as known, elongate.

Type species: A. elegans (Presl) K. Schum. in Bot. Jahrb. 27: 288 (1899) \& Pflanzenr. Zing. 352 (1904). Fig. 4B.

Other species: ?A. congesta Elmer; $A$. vanoverbergii Merr. Fig. 4A.

Distribution: The Philippines. Map 4.

It has already been remarked that only in sect. Kolowraxia have species with tubular bracteoles been placed with a species which has not. In $A$. vanoverbergii the bracts and bracteoles are open to the base, minute and soon deciduous, yet the character of the flowers is so similar to that of $A$. elegans that it would be inappropriate to separate them. The manner in which the corolla tube is exserted from the base (or near to the base) of the deeply split spathaceous calyx, i.e. held more or less at a right angle to it, is very striking.

\section{Sect. Alpinia}

Syn.: Albina Giseke, Prael. Ord. Nat. 207, 227, 248 (1792). Type: $A$. alba Giseke = Alpinia galanga $(\mathrm{L}.) \mathrm{Sw}$.

Martensia Giseke, op. cit. 207, 229, 248-non Martensia Hering (1841, nom. cons.). Type: $M$. aquatica Giseke = Alpinia aquatica (Retz.) Roscoe.

Zerumbet Wendl., Sert. Hannov. 4 : 3 (1798). Type: Zerumbet speciosum Wendl. = Alpinia zerumbet (Pers.) Burtt \& Smith.

Catimbium Lestib. in Ann. Sc. Nat. 2 sér. 15: 341 (1841) -non 
Catimbium Juss. (1798). Type: Alpinia zerumbet (Pers.) Burtt \& Smith.

Cenolophon Bl., Enum. Pl. Jav. 81 (1827). Type: C. rubrum Bl.[non Alpinia rubra Dietr. (1839)] = Alpinia rubricaulis K. Schum.

Languas J. K. Small, Fl. SEUS ed. 2, 307 (1913). Type: Alpinia zerumbet (Pers.) Burtt \& Smith.

Amomum subgen. Cenolophon (Bl.) Baker in Hook. f., Fl. Brit. Ind. 6: 242 (1892).

Alpinia subgen. Autalpinia (K. Schum.) K. Schum., Pflanzenr. Zing. 310 (1904) - p.p. incl. type: Alpinia galanga (L.) Sw.

Alpinia subgen. Probolocalyx K. Schum., Pflanzenr. Zing. 325 (1904)—p.p. incl. lectotype (selected here): Alpinia glabra Ridley.

Alpinia subgen. Catimbium (Horan.) K. Schum., op. cit. $321-$ p.p. incl. type: Alpinia zerumbet (Pers.) Burtt \& Smith.

Alpinia subgen. Catimbium sect. Flosparadisi K. Schum., op. cit. 333. Type: Alpinia zerumbet (Pers.) Burtt \& Smith.

Alpinia subgen. Catimbium sect. Boniophyton K. Schum., op. cit. 342. Lectotype (selected here): Alpinia tonkinensis Gagnep.

Alpinia sect. Ethanium Horan., Prodr. Monogr. Scitam. 33 (1862)-p.p. incl. type: Alpinia galanga (L.) Sw.

Alpinia sect. Catimbium Horan., op. cit. 34. Type: Alpinia zerumbet (Pers.) Burtt \& Smith.

Alpinia sect. Autalpinia K. Schum. in Bot. Jahrb. 27: 271, 272 (1899) - p.p. incl. type: Alpinia galanga (L.) Sw.

Alpinia sect. Hellenia K. Schum., Pflanzenr. Zing. 321 (1904)non Hellenia Willd.-p.p. incl. type: Alpinia galanga (L.) Sw. Alpinia sect. Cenolophon (B1.) K. Schum., op. cit. 320 - p.p. incl. type: Alpinia rubra (Bl.) R. M. Smith.

Alpinia sect. Presleia Val. in Bot. Jahrb. 52: 47, 64 (1914). Lectotype (selected here): Alpinia brevilabris Presl.

[Alpinia sect. Dieramalpinia K. Schum. in Bot. Jahrb. 27:286 (1899) - p.p. excl. type.]

[Alpinia sect. Allughas K. Schum., Pflanzenr. Zing. 344 (1904)p.p. excl. type.]

[Alpinia subgen. Dieramalpinia K. Schum., op. cit. $343-$ p.p. excl. type.]

Inflorescence erect or pendulous, branched or unbranched. Bracts often soon deciduous, rarely persistent, occasionally calyptrate, sometimes absent; flowers single or in cincinni. Capsule spherical or elongate.

Type species: A. galanga (L.) Sw., Obs. Bot. 6 (1791).

Distribution: Japan to New Guinea. Map 3. 


\section{Key to the Subsections of Section Alpinia}

1. Inflorescence truly paniculate (i.e. with lateral branches more or less throughout the inflorescence); flowers single; bracts calyptrate

Paniculatae

- Inflorescence unbranched or with one or two lateral branches at the base; flowers single or in cincinni; bracts, when present, rarely calyptrate and then inflorescence unbranched

2. Labellum deeply bilobed (except in $A$. romblonensis), the lateral lobes bifid thus forming a quadrate organ rarely more than $1 \mathrm{~cm}$ long; base of lip and filament usually joined to form a tube above the insertion of the petals Presleia

- Labellum sometimes bilobed but never quadrate, usually much larger; lip and filament not forming a tube

3. Bracteoles absent; bracts (sometimes none observed) minute or, in A. oxymitra, calyptrate; flowers single; inflorescence never branched

Cenolophon

- Bracteoles present, often soon deciduous; bracts present or not, never calyptrate; flowers in cincinni throughout at least part of the inflorescence; sometimes with lateral branches at the base

4. Labellum up to $2.5 \mathrm{~cm}$ long, commonly much less; bracteoles not completely enclosing the buds Alpinia

- Labellum rarely under $3 \mathrm{~cm}$ long, often much more; bracteoles usually completely enclosing the buds

5. Calyx deeply split at anthesis; anther ecristate; inflorescence unbranched

Catimbium

- Calyx not deeply split; anther crested; inflorescence usually with one or two lateral branches at base

Probolocalyx

Sect. Alpinia subsect. Alpinia

Syn.: Albina Giseke.

Alpinia subgen. Catimbium sect. Boniophyton K. Schum.-p.p. incl. lectotype.

Alpinia sect. Ethanium Horan.-p.p. incl. type.

Alpinia sect. Autalpinia K. Schum.-p.p. incl. type.

Alpinia sect. Hellenia K. Schum.--non Willd.-p.p. incl. type.

[Alpinia subgen. Probolocalyx K. Schum.-p.p. excl. type.]

Influorescence erect, sometimes with a few branches at the base. Bracts usually small and soon deciduous, sometimes larger and ? persistent; bracteoles open to the base or apparently lacking. Flowers in cincinni of two to many flowers; calyx not deeply split unilaterally; labellum flat or concave, sometimes unguiculate, the limb often shortly bilobed; lateral staminodes usually present; filament well formed, anther 
usually ecristate; stigma slightly expanded with a terminal orifice; epigynous glands small and, as far as is known, free from each other. Capsule spherical to ovoid.

Type species: A. galanga (L.) Sw., Obs. Bot. 6 (1791). Figs 1Ba, 3A.

Other species: A. bambusifolia Liang \& Fang; A. bilamellata Makino; A. boninsimensis Makino; A. breviligulata Gagnep.; A. brevis Wu \& Senjen; $A$. coriacea Wu \& Senjen; A. coriandriora Fang; $A$. densibracteata Wu \& Senjen; A. globosa (Lour.) Horan.; $A$. guandongensis Senjen \& Chen; $A$. intermedia Gagnep.; $A$. japonica (Thunb.) Miq.; $A$. jingxiensis Fang; A. kiushiana Kitamura; A. maclurei Merr., Fig. 5D; A. nanchuanensis Z. Y. Zhu; $A$. penduliftora Ridley; $A$. pinnanensis Wu \& Senjen; A. polyantha Fang; A. stachyoides Hance, Fig. 5C; A. strobiliformis Wu \& Senjen; A. suishaensis Hayata (A. chinensis auct. — non (Retz.) Roscoe), Fig. 1Bb; A. tonkinensis Gagnep.; A. velutina Ridley.

Distribution: Japan, China, Indo-China, Thailand, India, Malaysia, Indonesia and the Philippines. Map 7.

In general the species of subsect. Alpinia are small-flowered plants, the labellum rarely over $2 \mathrm{~cm}$ long and often much less. The type of sect. Boniophyton, A. tonkinensis (misplaced by Schumann in subgenus Catimbium), is curious in that the lateral staminodes have become connate to the base of the dorsal petal; the closely related $A$. globosa and $A$. maclure $i$ have similar staminodes.

Sect. Alpinia subsect. Presleia (Val.) R. M. Smith, stat. nov.

Syn.: Alpinia sect. Presleia Val. in Bot. Jahrb. 52: 47, 64 (1914)-incl. type.

Martensia Giseke, Prael. Ord. Nat. 207, 227, 248 (1792)-non

Martensia Hering (1841 - nom. cons.).

[Alpinia sect. Ethanium Horan., Prodr. Monogr. Scitam. 33 (1862)- - p.p. excl. type.]

[Alpinia sect. Autalpinia K. Schum. in Bot. Jahrb. 27: 271, 272 (1899) p.p.-excl. type.]

[Alpinia sect. Hellenia K. Schum., Pflanzenr. Zing. 312 (1904)p.p. excl. type.]

Inflorescence erect, occasionally with lateral branches at the base. Bracts soon deciduous, probably minute; bracteoles not seen. Flowers usually in cincinni of 2-3, small; calyx not split unilaterally; base of labellum occasionally connate to the base of the filament into a short tube above the insertion of the petals, the limb almost always bilobed, often deeply so, each lobe bifid; lateral staminodes present; filament well formed; anther crested or not; stigma \pm funnel-shaped, small; epigynous glands narrow, ventrally fused. Capsule round.

Lectotype: A. brevilabris Presl, Reliq. Haenk. 1: 110 t.17 (1830).

Other species: A. aquatica (Retz.) Roscoe, Fig. 5F; A. brachyanthera Merr.; $A$. cumingii K. Schum.; $A$. elmeri R. M. Smith; $A$. flabellata Ridley; $A$. foxworthyi Ridley; $A$. graminea Ridley; $A$. lauterbachii Val,; $A$. pubiflora (Bentham) K. Schum., Fig. 3B; $A$. pulchella K. Schum.; ? A. romblonensis Elmer; A. rosea Elmer, Fig. 1Bd; A. scabra (B1.) Baker; A. sibuyanensis Elmer; A. subspicata Val.; A. wenzlii Merr. 
Distribution: Malaysia, Indonesia, the Philippines, New Guinea, ? Japan, ? Taiwan. Map 8.

Subsect. Presleia is a well-defined group characterized by the very small flowers and 4-lobed labellum. A. romblonensis deviates in the entire labellum.

Sect. Alpinia subsect. Paniculatae R. M. Smith, subsect. nov.

Syn.: [Alpinia subgen. Probolocalyx K. Schum., Pflanzenr. Zing. 325 (1904) - p.p. excl. type.]

[Alpinia sect. Autalpinia K. Schum. in Bot. Jahrb. 27: 271, 272 (1899) - p.p. excl. type.]

Inflorescentia erecta, per longitudinem ramosa. Bracteae calyptratae, mox expulsae, parte basali saepe relicta; bracteolae absentes. Flores singuli; calyx haud unilateraliter fissus; labellum plus minusve concavum, integrum, minus quam $2 \mathrm{~cm}$ longum; staminodia lateralia praesentia; anthera cristata; stigma vix expansum ore terminali. Capsula globosa.

Type species: A. ligulata K. Schum. in Bot. Jahrb. 13: 275 (1899) \& Pflanzenr. Zing. 326 (1904).

Other species: $A$. nieuwenhuizii Val. Figs 1Bc, 5A.

Distribution: Borneo. Map 7.

Branched inflorescences are comparatively rare in Alpinia and usually have just one or two lateral branches which arise at the base of the main rhachis (e.g. in $A$.galanga and $A$. nigra). In subsect. Paniculatae the inflorescence is branched throughout. Care should be taken not to confuse the calyptrate bracts in this group with the calyptrate bracteoles of the much larger-flowered A. glabra (subsect. Probolocalyx).

Sect. Alpinia subsect. Cenolophon (B1.) R. M. Smith, stat. nov.

Syn.: Cenolophon Bl., Enum. Pl. Jav. 60 (1827).

Amomum subgen. Cenolophon (Bl.) Baker in Hook. f., Fl. Brit.

Ind. 6: 242 (1892) - p.p. incl. type.

Alpinia sect. Cenolophon (B1.) K. Schum., Pflanzenr. Zing. 320

(1904)-p.p. incl. type.

[Alpinia subgen. Probolocalyx K. Schum., Pflanzenr. Zing. 325

(1904) - p.p. excl. type.]

[Alpinia sect. Autalpinia K. Schum. in Bot. Jahrb. 27: 271, 272 (1899)-p.p. excl. type.]

Inflorescence usually erect, unbranched. Bracts very small, often the basal part remaining or early deciduous, rarely ( $A$. oxymitra) calyptrate; bracteoles absent. Flowers strictly single (rudimentary second flowers occasionally seen); calyx split unilaterally; labellum broad, showy \pm entire, the margin usually fimbriate; lateral staminodes present; filament well formed; anther crested or not; stigma expanded with a terminal orifice; epigynous glands often united on one side. Capsule ellipsoid or spherical.

Lectotype species: Cenolophon rubrum $\mathrm{Bl} .=A$. rubricaulis K. Schum.

Other species: $A$. argentea (Burtt \& Smith) R. M. Smith, Figs $3 \mathbf{H}, \mathbf{5 E} ; A$. corneri (Holttum) R. M. Smith; ? A. elwesii Turrill; A. gagnepainii K. Schum.; A. graminifolia 

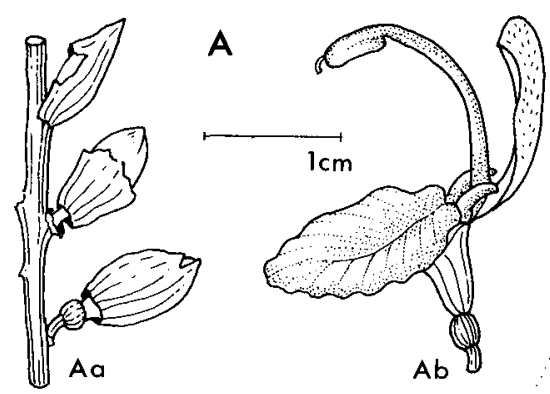

C

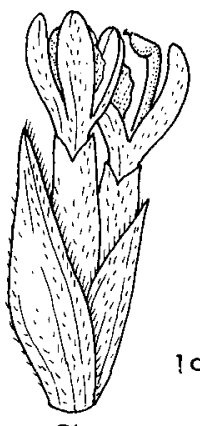

$\mathrm{Cb}$
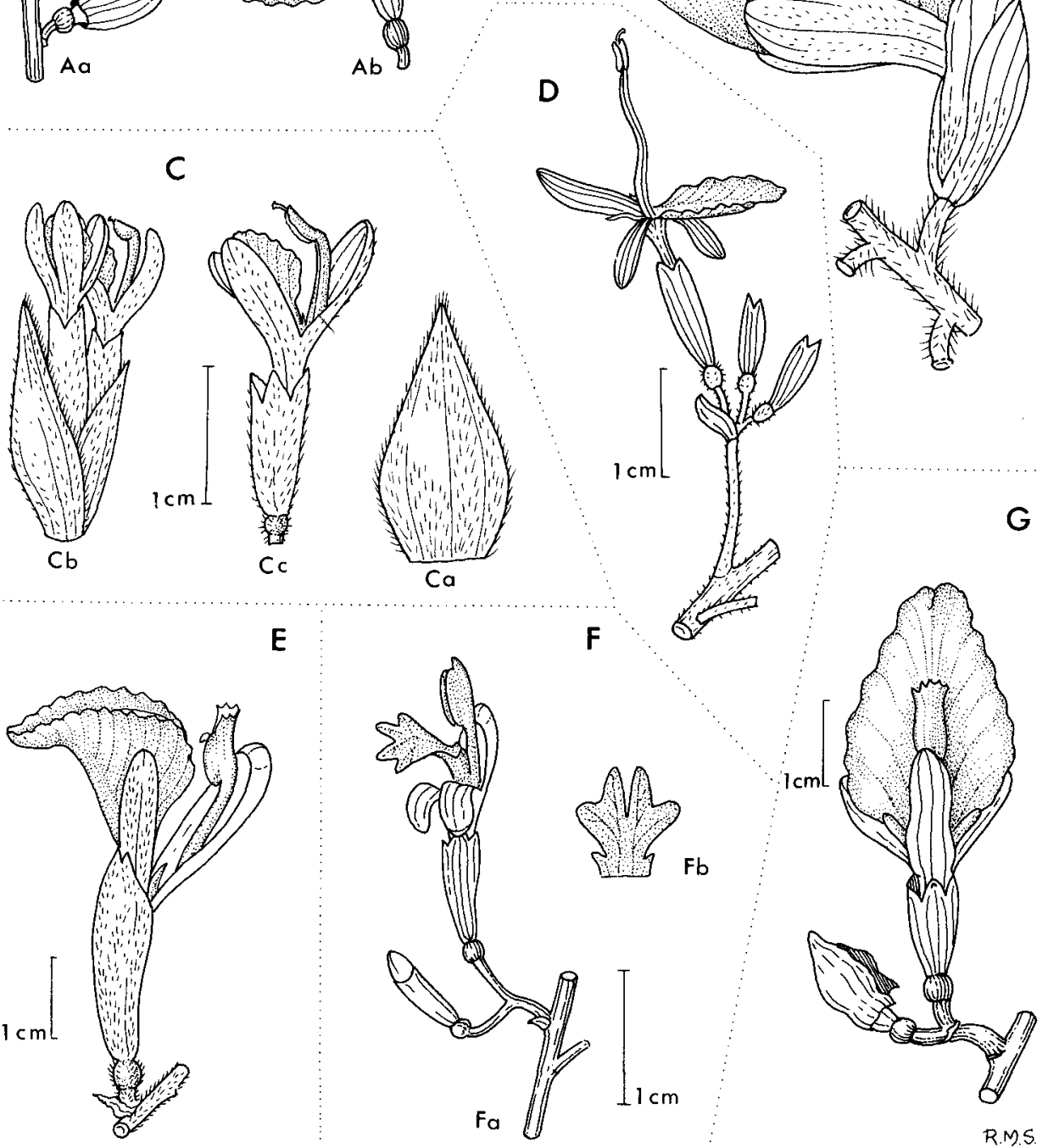

FIG. 5. Subgen. Alpinia sect. Alpinia. A, A. nieuwenhuizii (subsect. Paniculatae): Aa, part of main axis showing calyptrate bracts; Ab, flower. B, A. novaepommeraniae (subsect. Catimbium), flower. C, $A$. stachyoides (subsect. Alpinia): $\mathrm{Ca}$, bract; $\mathrm{Cb}$, cincinnus, bract removed; $\mathrm{Cc}$, flower. D, A. maclurei (subsect. Alpinia): Da, part of main axis and cincinnus with mature flower. E, A. argentea (subsect. Cenolophon) flower, with part of main axis. F, A. aquatica (subsect. Presleia): Fa, main axis and cincinnus with mature flower; Fb, labellum. G, A. glabra (subsect. Probolocalyx), main axis and cincinnus with mature flower, showing calyptrate bracteole. A, B, E, F, G from spirit material, C, D from dried material. 
Fang \& Lo; A. hansenii R. M. Smith; A. havilandii K. Schum.; A. hulstijnii Val.; $A$. macrostephana (Baker) Ridley; A. martinii R. M. Smith; A. mollissima Ridley; $A$. officinarum Hance; $A$. orthostachys K. Schum.; A. oxymitra K. Schum.; A. oxyphylla Miq.; A. padacanca Val.; A. petiolata Baker; A. pricei Hayata; A. ptychanthera K. Schum.; A. pulcherrima Ridley; ? A. shimadai Hayata; A. tamacuensis R. M. Smith; A. versicolor K. Schum.; A. vitellina (Lindley) Ridley; A. warburgii K. Schum. Distribution: China, Indo-China, Thailand, Malaysia and Indonesia. Map 10.

The type species of subsect. Cenolophon, C. rubra (Sulawesi, Reinwardt s.n.) was omitted from his monograph by Schumann on the grounds that the specimen had been lost. C. rubra has, however, since been recollected (Alston 15666, BM) from an area of Sulawesi visited by Reinwardt (Burtt \& Smith, 1975). Since the existence of Alpinia rubra Dietr. (1839) precludes the adoption of Blumes's epithet in Alpinia, A. rubricaulis K. Schum., placed in synonomy under Cenolophon rubrum by Burtt \& Smith (op. cit.) is here selected as lectotype of the section.

Sect. Alpinia subsect. Catimbium (Horan.) R. M. Smith, stat. nov.

Syn.: Alpinia sect. Catimbium Horan., Prodr. Monogr. Scitam. 34 (1868)-p.p. incl. type.

Zerumbet Wendl., Sert. Hannov. 4: 3 (1798).

Catimbium Lestib. in Ann. Sci. Nat. 2 sér. 15: 346 (1841) —non Catimbium Juss. (1798).

Languas J. K. Small, Fl. SEUS ed. 2, 307 (1913).

Alpinia subgenus Catimbium (Horan.) K. Schum. sect. Flosparadisi K. Schum., Pflanzenr. Zing. 321 (1904)—p.p. incl. type.

[Alpinia subgen, Probolocalyx K. Schum., op. cit. 325-p.p. excl. type.]

[Alpinia sect. Ethanium Horan., Prodr. Monogr. Scitam. $33-$ p.p. excl. type.]

Inflorescence erect or pendulous. Bracts absent; bracteoles almost always enclosing the flower buds, sometimes joined at the base initially, falling soon. Flowers in cincinni of $2-4$, rarely single; calyx split unilaterally; labellum usually over $3 \mathrm{~cm}$ long, commonly yellow-orange heavily marked crimson red, convolute, usually \pm three-lobed; lateral staminodes present, often reduced to fleshy swellings; filament well formed; anther ecristate; stigma expanded with a narrow hairy orifice; epigynous glands massive. Capsule spherical to ellipsoid.

Lectotype species: A. zerumbet (Pers.) Burtt \& Smith in Notes RBG Edinb. 31: 204 (1972). Fig. 3E, Plate 1B.

Other species: $A$. assimilis Ridley; $A$. auriculata Roscoe; $A$. blepharocalyx K. Schum.; A. bracteata Roscoe; $A$. calcarata Roscoe, Fig. 1Be; $A$. chrysorhachis K. Schum.; $A$. copelandii Ridley; $A$. diffisa Roscoe; $A$. dolichocephala Hayata; $A$. emaculata Tong; A. formosana K. Schum.; A. glabrescens Ridley; A. guinanensis Fang \& Cheng; $A$. haenkei Presl; $A$. hainanensis K. Schum.; A. henryi K. Schum.; ? A. hirsuta (Lour.) Horan.; A. illustris Ridley; A. katsumadai Hayata; A. kwangsiensis Wu \& Senjen; $A$. 

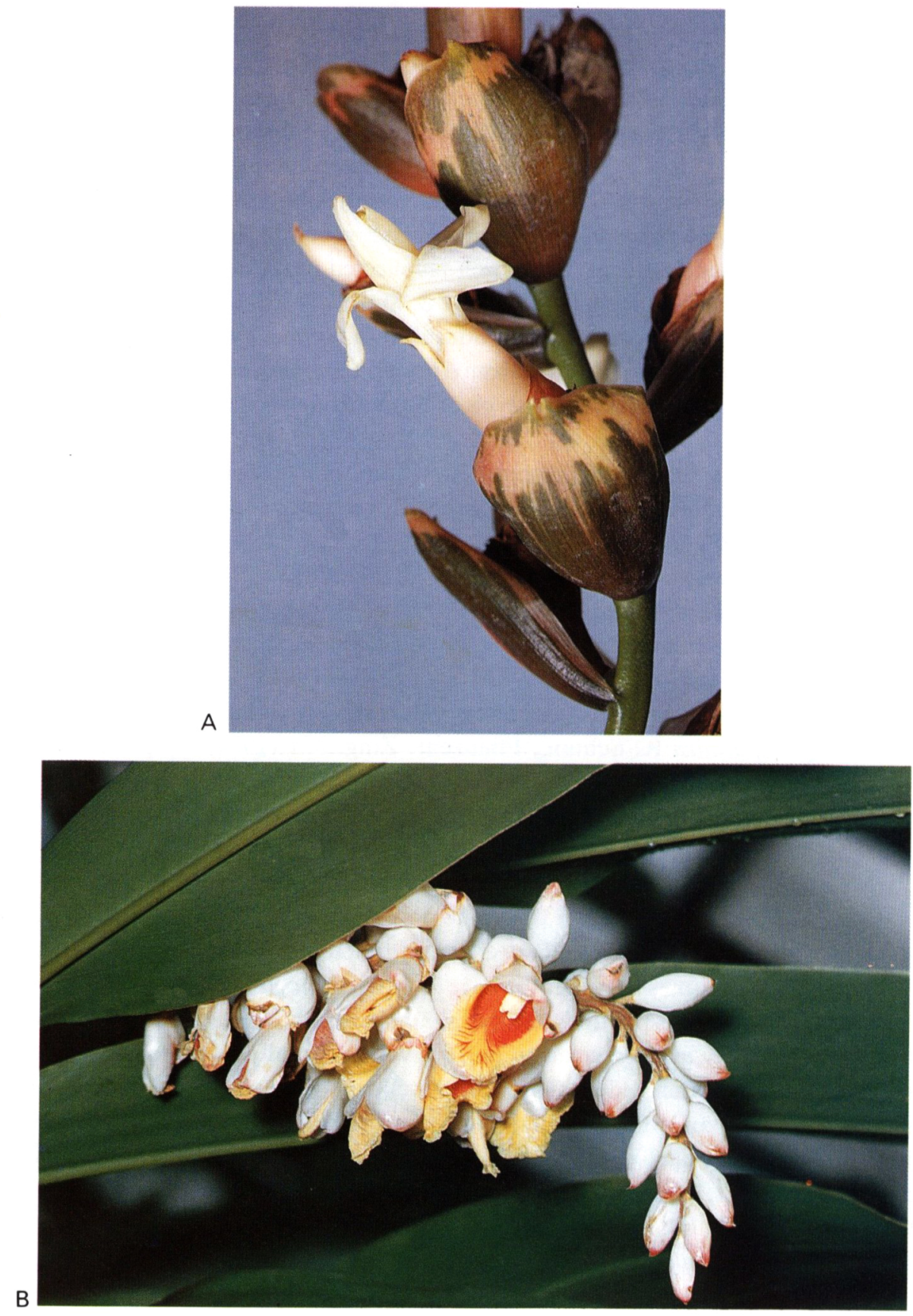

Plate 1. A, Alpinia vittata Bull. (subgenus Dieramalpinia). B, Alpinia zerumbet (Pers.) Burtt \& Smith (subgenus Alpinia). 
latilabris Ridley;? A. macroscaphis K. Schum.; A. macroura K. Schum.; A. malaccensis (Burm.) Roscoe; A. novae-pommeraniae K. Schum., Fig. 5B; A pennicellata Roscoe; A. platychilus K. Schum.; A. romburgiana Val.; A. schumanniana Val.; A. sessiliflora Kitamura; ? A. trachyascus K. Schum.; A. uraiensis Hayata.

Distribution: China, Indochina, India, Burma, Thailand, Malaysia, Indonesia, New Guinea and the Bismarck Archipelago. Map 9.

The dividing line between subsections Cenolophon and Catimbium is not clear-cut. Cenolophon, as understood by Blume, is strictly single-flowered with very small primary bracts, no bracteoles and a prominent anther crest. Subsect. Cenolophon now includes species with ecristate anthers, $A$. havilandii for example-a Bornean endemic with minute bracts and flowers borne singly. In the showy labellum this species strongly resembles subsect. Catimbium where at least partially single-flowered inflorescences are known (A. latilabris).

Sect. Alpinia subsect. Probolocalyx (K. Schum.) R. M. Srrith, stat. nov.

Syn.: Alpinia subgen. Probolocalyx K. Schum., Pflanzenr. Zing. 325 (1904) - p.p: incl. type: A. glabra Ridley.

[Alpinia sect. Autalpinia K. Schum. in Bot. Jahrb. 27: 271, 272 (1899)- p.p. excl. type.]

Inflorescence sometimes with short lateral branches at the base. Bracts membranous and soon deciduous, rarely seen in the dried state; bracteoles calyptrate, pushed off by the opening flower, sometimes splitting to the base. Flowers in cincinni of 2-3, often only one developing; calyx not deeply split unilaterally; labellum convolute; lateral staminodes present; anther crested. Capsule spherical.

Lectotype species: A. glabra Ridley in J. Str. Br. Roy. Asiat. Soc. 32: 168 (1899). Figs 3D, 5G.

Distribution: Borneo. Map 9.

Schumann believed that his subgenus Probolocalyx, which he characterized by the minute (or absent) bracts and bracteoles, lay between his subgenera Alpinia and Catimbium. Of the 19 species included in Probolocalyx, eight are here placed in subsect. Cenolophon, three in subsect. Catimbium, and one in subsections Alpinia and Paniculatae respectively. A. submutica is imperfectly known, and two have been transferred to Riedelia. The remaining three species were united under $A$. glabra by Burtt \& Smith (1972). Since then much more material has become available and there is every indication that more than a single species is involved.

While A. glabra resembles the species of subsect. Catimbium in the labellum shape, it is well distinguished by the initially calyptrate bracteoles, crested anther, and the calyx, which is not deeply split unilaterally.

Sect. Fax R. M. Smith, sect. nov.

Syn.: Amomum sect. Geanthus K. Schum. series Polyanthae K. Schum., Pflanzenr. Zing. 225 (1904)-p.p. incl. lectotype (selected here): Elettaria involucrata Thwaites = Alpinia fax Burtt \& Smith. 
[Alpinia sect. Cenolophon (Bl.) K. Schum., op. cit. 320-p.p. excl. type.]

Inflorescentia erecta, haud ramosa, in fronde foliato terminalis vel radicalis, dense congesta et involucro bractearum sterilium circumcincta. Bracteae fertiles exteriores sterilibus similes, interiores angustiores; bracteolae saepissime tubulares. Flores in cincinnos dispositi (paucis in inflorescentia radicali interdum solitariis exceptis); calyx unilateraliter fissus; labellum inconspicuum, obscure trilobum; staminodia lateralia praesentia vel absentia; anthera sessilis, ecristata; stigma clavatum, ore plus minusve ventrali. Capsula globosa vel oblonga.

Lectotype species: A. fax Burtt \& Smith in Notes RBG Edinb. 34: 177 f.5 (1975).

Other species: A. abundiflora Burtt \& Smith, Figs 3G, 6D; A. rufescens (Thwaites) K. Schum.

Distribution: Sri Lanka; S India. Map 4.

All three members of sect. Fax were first described in Elettaria (Thwaites, 1861) and all were later transferred to Amomum by Trimen $(1885,1898)$ but the decision to place them in Alpinia is probably correct. In A. rufescens, which is known from the type plant alone, the inflorescence is terminal on the leafy shoot; that of $A$. abundiflora may be terminal but is more often radical, whereas in $A$. fax only radical inflorescences are known. Such diversity of habit is not unique in Zingiberaceac either at specific (Zingiber wightianum) or generic level (Renealmia, Riedelia).

The conspicuous involucre of sterile bracts which surrounds the inflorescence is a prominent characteristic of sect. Fax. Such bracts are never found in Amomum. Sterile bracts may occur in some species of Alpinia sect. Dieramalpinia, but they are never involucre-like and are usually not clearly differentiated from the bracts which subtend the flowers.

The bracteoles of $A$. fax are tubular, those of $A$. abundiflora usually open to the base, but this feature is not constant and tubular and non-tubular bracteoles may be found in the same cincinnus (Burtt \& Smith, 1975).

Sect. Guillainia (Vieill.) K. Schum., Pflanzenr. Zing. 323 (1904).

Syn.: Guillainia Vieill. in Bull. Soc. Linn. Normand. 10: 92 (1866).

Type: Guillainia purpurata Vieill.

Alpinia sect. Kolowratia (Presl) Loesen. subsect. Guillainia (Vieill.) Loesener, Pflanzenfam. ed 2 15a: 621 (1930)—p.p. incl. type: Alpinia purpurata (Vieill.) K. Schum.

[Alpinia sect. Autalpinia K. Schum. in Bot. Jahrb. 27: 271, 272 (1899) - p.p. excl. type.]

Inflorescence erect, unbranched. Bracts large, persistent, usually coloured; bracteoles tubular. Flowers in cincinni; calyx not split unilaterally; corolla tube long, well exserted from the calyx; labellum broad, variously lobed, lateral staminodes absent; anther \pm sessile, crested; stigma hard, expanded, unilaterally flattened with a terminal orifice; epigynous glands narrow, usually united on one side. Capsule spherical or flaskshaped. 
Type species: A. purpurata (Vieill.) K. Schum., Pflanzenr. Zing. 323 (1904). Figs 3C, 6C.

Other species: A. fusiformis R. M. Smith; A. ludwigiana R. M. Smith.

Distribution: New Caledonia, New Hebrides, New Guinea, the Solomons, the Moluccas, the Bismarck Archipelago, Java and the Carolines. Map 5.

A. ludwigiana is native to Java and $A$. fusiformis to New Guinea. The well known A. purpurata, which was described from New Caledonia, is widely cultivated throughout the tropics and may not be truly native in all the areas listed above.

The stigma of $A$. purpurata approaches that of some members of subgen. Dieramalpinia in that it is very rigid and flattened on the ventral surface. The orifice is, however, terminal.

Sect. Arctiflorae R. M. Smith, sect. nov.

Syn.: [Alpinia sect. Allughas K. Schum., Pflanzenr. Zing. 344 (1904)p.p. excl. type.]

Inflorescentia plus minusve erecta, ramosa. Bracteae persistentes conspicuae; bracteolae tubulares. Flores in cincinnos dispositi; calyx plus minusve unilateraliter fissus; labellum tam latum quam longum, breviter bilobum, staminodia lateralia absentia vel praesentia; anthera subsessilis, thecis valde divergentibus, crista conspicua plus minusve petaloidea vel absente; stigma clavatum, paulo expansum ore ventrali; glandulae epigynae brevis, inter se liberae. Capsula elongata.

Type species: A. arctiflora F. Muell., Fragm. 8: (1872). Monotypic. Fig. 6B.

Other species: A. sp. nov.? (Nagata 3861, E).

Distribution: Australia. Map 5.

The stigma of $A$. arctiflora closely approaches that of some species of sect. Pycnanthus in subgenus Dieramalpinia, but in other respects the species is very different from the members of that section. The labellum is large and showy and the more or less petaloid anther crest is the largest of the genus. It appears to have no close affinity to the other groups of Alpinia. A second and as yet undescribed species from N Queensland also belongs here. It differs in the absence of an anther-crest, in the presence of subapical teeth on the very short filament, and in its smaller stature.

Sect. Allughas K. Schum., Pflanzenr. Zing. 344 (1904).

Syn.: Heritiera Retz., Obs. Bot. 6: 17 (1791)-non Heritiera Aiton (1798). Type: H. allughas Retz. = Alpinia nigra (Gärtner) B. L. Burtt.

Buekia Giseke, Prael. Ord. Nat. 204, 216, 239 (1792). Type: Costus malaccensis König $=$ ? Alpinia javanica $\mathrm{Bl}$.

Hellenia Willd., Sp. Pl. 1: 4 (1797)—non Hellenia Retz. (1791).

Type: $H$. allughas (Retz.) Willd. = Alpinia nigra (Gärtner) B. L. Burtt.

Strobidia Miq., Fl. Ind. Bat. Suppl. 614 (1860). Type: S. sumatrana Miq. = Alpinia sumatrana (Miq.) K. Schum.

Odontychium K. Schum., Pflanzenr. Zing. 59 (1904). Type: Hedy- 


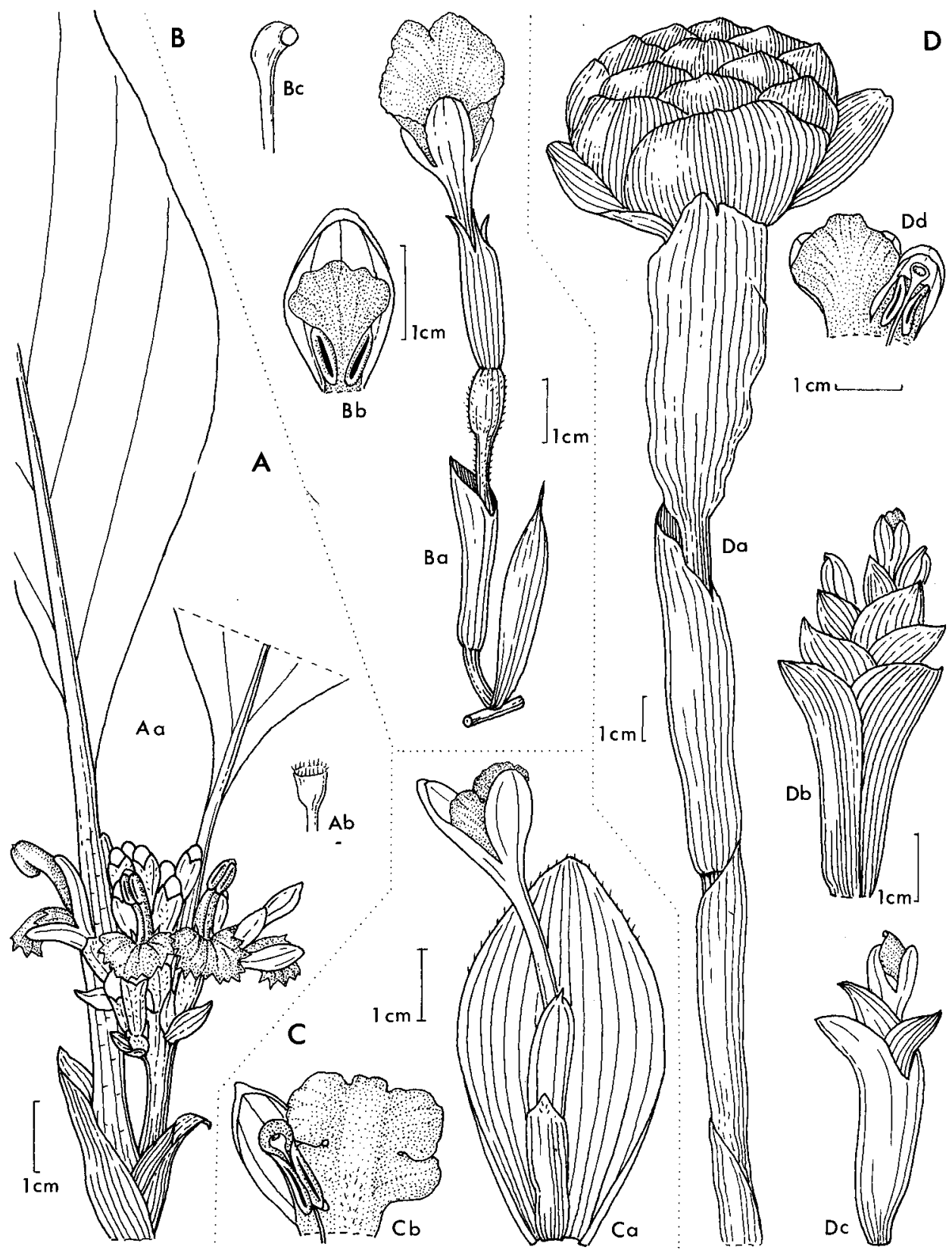

Fig. 6. Subgenus Alpinia. A, A. pumila (sect. Didymanthus): Aa, habit; Ab, stigma. B, A arctiflora (sect. Arctiflorae): Ba, cincinnus; Bb, anther and dorsal petal; Bc, stigma. C, A. purpurata (sect. Guillainia): $\mathrm{Ca}$, cincinnus, within bract; $\mathrm{Cb}$, upper part of flower, dissected. D, A abundiflora (sect. Fax): Da, habit; Db, cincinnus showing first, non-tubular bracteoles; Dc, cincinnus showing tubular bracteoles; Dd, upper part of flower, dissected. A, after Bot. Mag. t.6832; B, C, Dc, b, d from spirit material; Da from dried material. 
chium denticulatum Ridley = Alpinia denticulata (Ridley) Holttum.

Alpinia sect. Ethanium Horan., Prodr. Monogr. Scitam. 33 (1862)-p.p. incl. type: Alpinia allughas (Retz.) Roscoe $=A$. nigra (Gärtner) B. L. Burtt.

Alpinia sect. Brachybotrys K. Schum., Pflanznr. Zing. 358 (1904).

Type: Alpinia rafflesiana Wall. ex Baker.

Alpinia sect. Javana K. Schum., op. cit. 359. Type: Alpinia javanica $\mathrm{Bl}$.

Alpinia sect. Strobidia (Miq.) K. Schum., op. cit. 357. Type: Alpinia sumatrana (Miq.) K. Schum.

[Alpinia sect. Catimbium Horan., op. cit. 34-p.p. excl. type.]

[Alpinia sect. Dieramalpinia K. Schum. in Bot. Jahrb. 27: 286 (1899) p.p. - excl. type.]

[Alpinia sect. Hellenia K. Schum., Pflanzenr. Zing. 312-p.p. excl. type.]

[Alpinia sect. Amomiceps K. Schum., op. cit. 350-p.p. excl. type.]

Inflorescence erect, rarely pendulous, sometimes with branches at the base. Bracts often small and soon deciduous, occasionally large and more or less persistent; bracteoles tubular. Flowers always in cincinni; calyx not markedly split unilaterally; labellum usually flat or concave, rarely linear. Capsule spherical.

Type species: A. nigra (Gärtner) B. L. Burtt in Notes RBG Edinb. 35: 213 (1977). Distribution: China, India, Burma, Thailand, Malaysia, Indonesia, New Guinea, Australia. Map 6.

\section{Key to the Subsections of Section Allughas}

1. Dorsal petal with a conical cucullate apex; labellum up to $4 \mathrm{~cm}$ long, always exceeding $1 \mathrm{~cm}$

- Dorsal petal rounded and more or less hooded at the apex; labellum usually under $1 \mathrm{~cm}$ long

2. Labellum $2-3 \mathrm{~mm}$ wide in lower two thirds Odontychium

- Labellum much wider Allughas

3. Mature fruit black or red; labellum with a callus-like appendage at the base Strobidia

- Mature fruit blue; labellum without a callus Cacruleae

Sect. Allughas subsect. Allughas (K. Schum.) R. M. Smith, stat. nov.

Syn.: Alpinia sect. Allughas K. Schum., Pflanzenr. Zing. 344 (1904)p.p. incl. type.

Heritiera Retz., Obs. Bot. 6: 17 (1791)—non Heritiera Aiton (1798). 
Buekia Giseke, Prael. Ord. Nat. 204, 216, 239 (1792).

Hellenia Willd., Sp. Pl. 1: 4 (1797)—non Hellenia Retz. (1791).

Alpinia sect. Brachybotrys K. Schum., Pflanzenr. Zing. 358 (1904).

Alpinia sect. Javana K. Schum., op. cit. 359.

[Alpinia sect. Ethanium (Salisb.) Horan., Prodr. Monogr. Scitam.

33 (1862)-excl. type.]

[Alpinia sect. Amomiceps K. Schum., op. cit. 350--p.p. excl. type.]

Inflorescence usually erect, sometimes branched. Bracts usually small and soon deciduous, rarely large and persistent. Dorsal petal with a conical cucullate apex; labellum 1-4cm wide, bilobed or entire; stigma more or less funnel-shaped.

Type species: A. nigra (Gärtner) B. L. Burtt. Fig. 1Bg.

Other species: $A$. borraginoides K. Schum.; A. capitellata Jack; $A$. javanica Bl.; $A$. microlophon Ridley; A. murdochii Ridley, Fig. 1Bh; A. pahangensis Ridley, Fig. 7D; $A$. rafflesiana Wall. ex Bak., $A$. seimundii Ridley, Fig. 7B.

Distribution: China, India, Burma, Malaysia, Indonesia (Java). Map 11.

Sect. Allughas subsect. Odontychium (K. Schum.) R. M. Smith, comb. et stat. nov.

Syn.: Odontychium K. Schum., Pflanzenr. Zing. 59 (1904).

Dorsal petal cucullate; labellum 2-3mm wide in the lower two thirds, slightly expanded into three lobes (the mid-lobe bifid) at the apex; non-petaloid.

Type species: A. denticulata (Ridley) Holttum in Gard. Bull. Sing. 13: 143 (1950). Fig. 7 A.

Monotypic.

Distribution: W Malaysia. Map 12.

A. denticulata was first described in Hedychium on account of its $6 \mathrm{~mm}$ long lateral staminodes; these are in fact no longer than those of many other Alpinia (e.g. A. glabra). Schumann placed his new genus in the Hedychieae, but pointed out that in every other character of the inflorescence and in the fruit, it belonged to his subgen. Dieramalpinia. The curious non-petaloid labellum makes $A$. denticulata anomalous in sect. Allughas when it is treated as a section of subgen. Alpinia, but the elongate, rather papery tubular bracteoles and prominently cucullate dorsal corolla lobe give $A$. denticulata the general facies of $A$. pahangensis and $A$. rafflesiana with which it shares a similar distribution.

Sect. Allughas subsect. Strobidia (Miq.) R. M. Smith, stat. nov.

Syn.: Strobidia Miq., Fl. Ind. Bot. Suppl. 614 (1860).

Alpinia sect. Strobidia (Miq.) K. Schum., Pflanzenr. Zing. 357

(1904).

[Alpinia sect. Dieramalpinia K. Schum. in Bot. Jahrb. 27: 272,

286 (1899) - p.p. excl. type.]

Dorsal petal rounded, hood not pointed; labellum strongly concave with a wart-like callus at the base. Capsule red or black. 

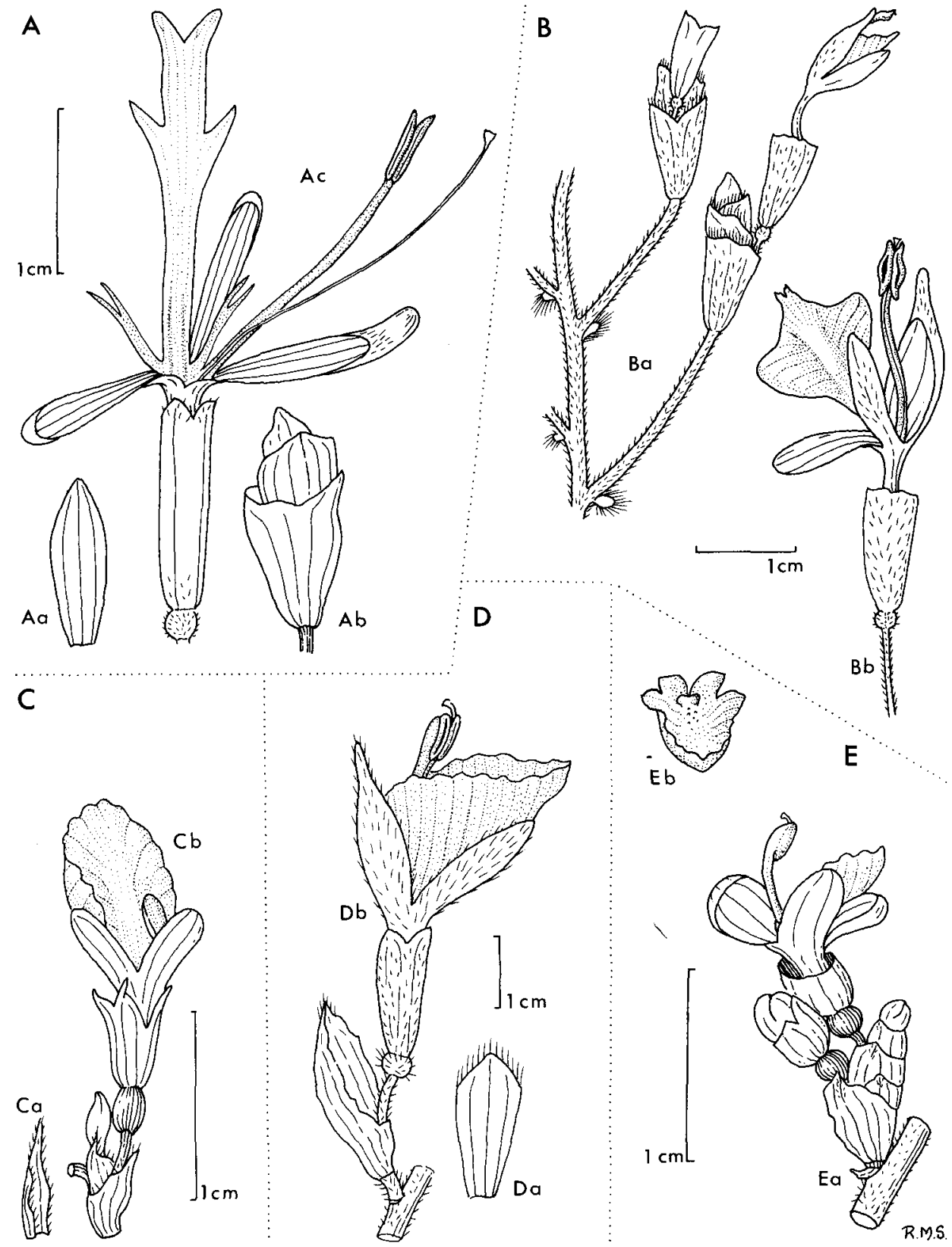

Fig. 7. Alpinia subgen. Alpinia sect. Allughas. A, A. denticulata (subsect. Odontychium): Aa, bract; Ab, young cincinnus; Ae, flower. B, A. siemundii (subsect. Allughas): Ba, part of main axis showing bracts and two cincinni; $\mathrm{Bb}$, flower. $\mathrm{C}$, A. modesta (subsect. Caerulea): $\mathrm{Ca}$, bract; $\mathrm{Cb}$, cincinnus and mature flower. $\mathrm{D}$, A. pahangensis (subsect. Allughas): $\mathrm{Da}$, bract; $\mathrm{Db}$, cincinnus and mature flower. $\mathrm{E}, A$. conchigera (subsect. Strobidia): Ea, cincinnus and mature flower; Eb, labellum. All from dried material, except C (spirit). 
Type species: A. sumatrana (Miq.) K. Schum. in Bot. Jahrb. 27: 291 (1899).

Other species: A. conchigera Griff., Fig. 7E; A. siamensis K. Schum.; ?A. mannii Baker.

Distribution: The Andamans, Indo-China, Thailand, Malaysia, Indonesia (Sumatra). Map 13.

Subsect. Strobidia is closely allied to subsect. Allughas, differing in the smaller flowers and the rounded, not pointed, dorsal petal.

Sect. Allughas subsect. Caeruleae R. M. Smith, subsect. nov.

Syn.: [Alpinia sect. Hellenia K. Schum., Pflanzenr. Zing. 312 (1904)-

p.p. excl. type.]

[Alpinia sect. Allughas K. Schum., op. cit. 344-p.p. excl. type.]

Petalum dorsale plus minusve rotundatum; labellum non valde concavum, callo absente. Capsula caerulea.

Type species: A. caerulea Bentham, Fl. Austr. 6: 265 (1873). Fig. 1Bf.

Other species: $A$. arundelliana (F. M. Bailey) K. Schum.; $A$. hylandii R. M. Smith; $A$. modesta (F. Muell.) K. Schum. Fig. 7c.

Distribution: Australia, New Guinea. Map 14.

The distribution of sect. Allughas is made somewhat disjunct by the inclusion of these Australian plants. However, subsect. Caeruleae is closely allied to subsects Allughas and Strobidia, differing from the former in the smaller flowers and nonpointed dorsal petal and from the latter in the absence of a callus at the base of the lip. The blue capsules of subsect. Caeruleae are unique in the section. It is probable that $A$. caerulea also occurs in Papua New Guinea but further material is needed to verify this.

\section{Key to the Sections of Subgenus Dieramalpinia}

1. Filament subapically dentate; stigma \pm clavate with a rounded orifice ventrally or sub-ventrally, or geniculate, the orifice at the tip; labellum linear or oblong; bracts usually inconspicuous, rarely ( $A$. macrocephala) involucre-like; inflorescence, as far as is known, never monoecious

Pycnanthus

- Filament edentate; stigma expanded, often rigid with an elliptic orifice on the ventral face, rarely funnel-shaped; labellum never linear, usually more or less triangular or oblong; bracts conspicuous or not, often persistent; inflorescence sometimes monoecious

2. Base of labellum and filament joined into a distinct tube above the insertion of the petals; stigma, as far as known, funnelshaped; sometimes monoecious Eubractea

- Base of lip and filament not so joined; stigma rigid with a ventral orifice; monoecious or not

3. Bracts usually small or absent; filament broad, well formed; 
monoecism always displayed, only the first, rarely the second flower of the cincinnus producing fruit Myriocrater

- Bracts almost always conspicuous, usually persistent; anther sessile or subsessile (except in $A$. carolinensis); plants, as far as known, never monoecious

Dieramalpinia

Sect. Pycnanthus K. Schum., Pflanzenr. Zing. 346 (1904); R. M. Smith in Notes RBG Edinb. 36: 273 (1978); A. C. Smith, Fl. Vitiens. Nova 1: 202 (1979).

Syn.: Hellwigia Warb. in Bot. Jahrb. 13: 279, 451 (1891). Type: $H$. pulchra Warb. = Alpinia pulchra (Warb.) K. Schum. Alpinia subgen. Monanthocrater (Val.) Loesener, Pflanzenfam. ed. 2, 15a: 618 (1930). Type: Alpinia odontonema K. Schum. Alpinia sect. Amomiceps K. Schum. Pflanzenr. Zing. 350 (1904)--p.p. incl. lectotype (selected here): A. macrocephala K. Schum.

Alpinia sect. Monanthocrater Val. in Nova Guinea (Botanique) 8: 951 (1913). Lectotype (selected here): Alpinia odontonema K. Schum.

Alpinia sect. Hellwigia (Warb.) Loesener op. cit. 619. Type: Alpinia pulchra (Warb.) K. Schum.

[Eriolopha Ridley in Hooker's Icon. Pl. 31: t.3067 (1916) \& in Trans. Linn. Soc. (Bot.) 217 (1916)-p.p. excl. type.]

[Alpinia sect. Hellenia K. Schum., Pflanzenr. Zing. 312 (1904)p.p. excl. type.]

Inflorescence erect or pendulous, branched or unbranched. Bracts small and inconspicuous or apparently absent, occasionally well formed, rarely involucre-like; bracteoles tubular. Flowers borne singly or in cincinni; calyx not unilaterally split; labellum linear or narrowly oblong; lateral staminodes absent; filament usually well formed, always subapically dentate, anther rarely crested; stigma clavate with a rounded orifice subventrally or geniculate, the orifice at the tip; epigynous glands massive, splitting irregularly. Capsule spherical.

Lectotype species: A. boia Seeman, Fl. Vit. 290, t.88 (1868).

Distribution: New Guinea, the Bismarck Archipelago, New Hebrides, Fiji and Samoa. Map 18.

\section{Key to the Subsections of Sect. Pycnanthus}

1. Bracts usually small and inconspicuous, never involucre-like; labellum strap-shaped or oblong Pycnanthus

- Bracts large and involucre-like; labellum linear with a small expanded petaloid apex Amomiceps

Sect. Pycnanthus K. Schum. subsect. Pycnanthus R. M. Smith, stat. nov.

Syn.: Hellwigia Warb. in Bot. Jahrb. 13: 279, 451 (1891). 
Eriolopha Ridley in Hooker's Icon. Pl. 31: t.3067 (1916) \& in Trans. Linn. Soc. Bot. 9: 217 (1916)-p.p. excl. type. Alpinia subgen. Monanthocrater (Val.) Loesener, Pflanzenfam. ed. 2, 15a: 618 (1930).

Alpinia sect. Monanthocrater Val. in Nova Guinea (Botanique) 8: 951 (1913).

Alpinia sect. Hellwigia (Warb.) Loesener, Pflanzenfam. ed. 2, 15a: 619 (1930).

Bracts usually small and inconspicuous, occasionally apparently absent. Flowers borne singly or in cincinni; labellum linear or narrowly oblong; filament always with subapical teeth.

Lectotype species: A. boia Seeman, Fl. Vit. 290 (1868). Figs 2F, 8C.

Other species: $A$. acuminata R. M. Smith; $A$. albipurpurea (van Royen) R. M. Smith; $A$. athroantha Val.; $A$. conglomerata $\mathrm{R}$. M. Smith; $A$. divaricata Val.; $A$. dyeri $\mathrm{K}$. Schum.; A. hageana R. M. Smith; $A$. himantoglossa Ridley; $A$. horneana $\mathrm{K}$. Schum., Fig. 1Aj; $A$. inaequalis (Ridley) Loesener, Fig. 1Ah; $A$. nidus-vespae Raynal; $A$. odontonema K. Schum.; A. parksii A. C. Smith; A.porphyrea R. M. Smith; A. pulchra (Warb.) K. Schum., Fig. 2E; $A$. rigida Ridley; A. samoensis Reinecke, Fig. 1Ai; $A$. singuliffora R. M. Smith, Fig. 1Ak; $A$. stenobracteolata R. M. Smith, Fig. 8A; $A$. subverticillata Val.; A. velveta R. M. Smith; $A$. vitiensis Seeman; $A$. werneri Val.; $A$. womersleyi $\mathrm{R}$. M. Smith.

Distribution: as for the section. Map 18.

This is a well-defined group characterized by the small subapical teeth on the usually well-formed filament. In the majority of the species the stigma is clavate with a rounded orifice and often well exserted from the thecae. In A. boia, A. horneana, $A$. parksii (all from Fiji), A. nidus-vespae (New Hebrides) and $A$. samoensis it is geniculate and very similar to the stigmas of Psychanthus and some Riedelia.

Sect. Pycnanthus subsect. Amomiceps (K. Schum.) R. M. Smith, stat. nov.

Syn.: Alpinia sect. Amomiceps K. Schum., Pflanzenr. Zing. 350 (1904) - p.p. incl. type.

Inflorescence massive, tightly congested. Bracts large and involucre-like; labellum linear, the apex expanded into a small petaloid area.

Lectotype species: A. macrocephala K. Schum., Pflanzenr. Zing. 350 (1904). Fig. 1 Al. Monotypic.

Distribution: Fiji. Map 18.

The large congested inflorescence gives $A$. macrocephala an aspect quite unlike the species of subsect. Pycnanthus. However, the presence of teeth on the well-formed filament and the clavate stigma indicate that $A$. macrocephala is correctly placed within sect. Pycnanthus. Schumann also included the not closely related $A$. capitellata Jack in his sect. Amomiceps, this species is here placed in subgen. Alpinia sect. Allughas.

Sect. Eubractea K. Schum., Pflanzenr. Zing. 352 (1904).

Syn.: [Alpinia sect. Dieramalpinia K. Schum. in Bot. Jahrb. 27: 272, 286 (1899)—p.p. excl. type.] 


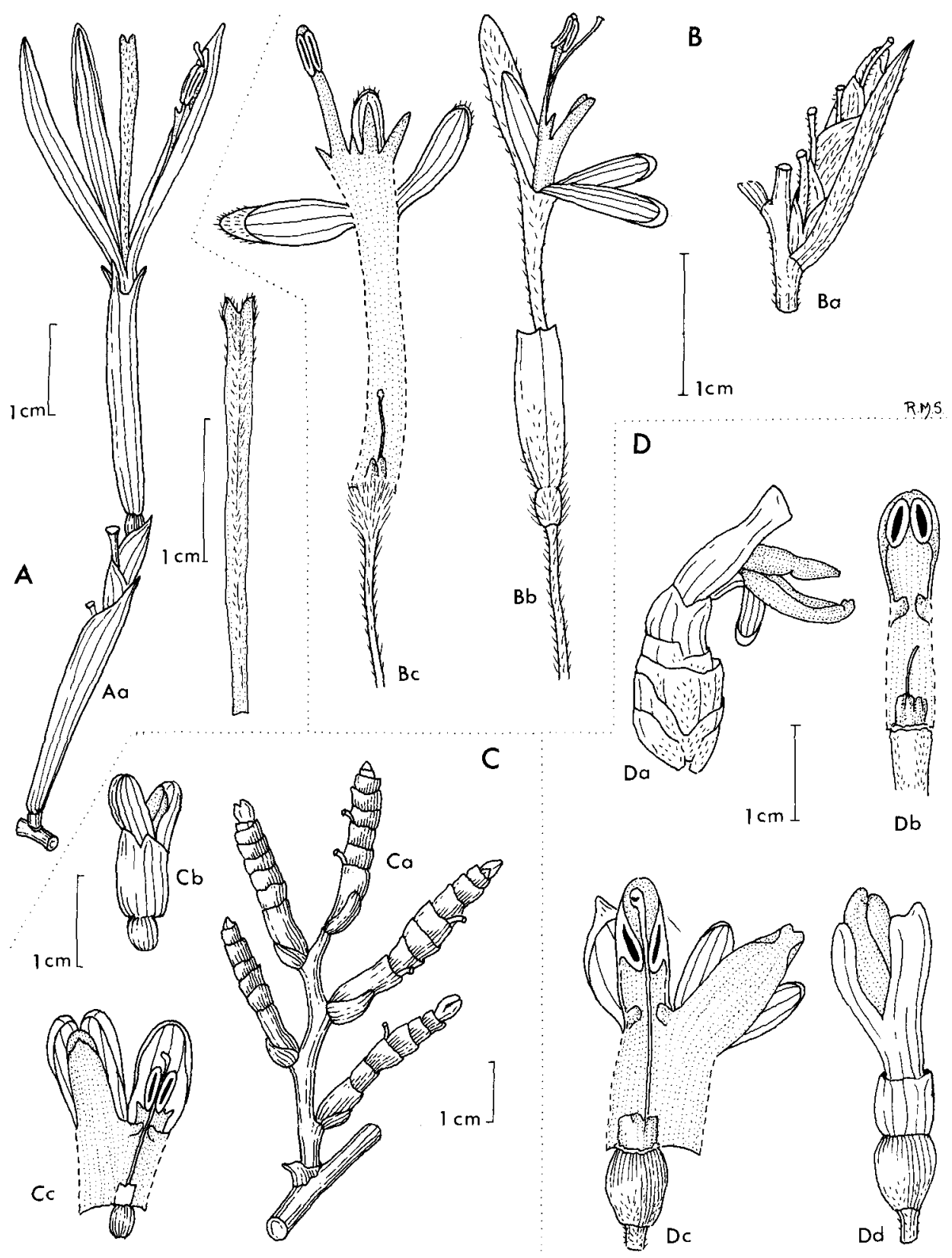

FIG. 8. Subgen. Dieramalpinia. A, A. stenobracteolata (sect. Pycnanthus): Aa, cincinnus and mature flower; Ab, labellum. B, A. rufa (sect, Eubractea): Ba, part of main axis with old cincinnus; Bb, flower; Bc, flower, dissected. C, A. boia (sect. Pycnanthus): $\mathrm{Ca}$, lateral branch with cincinni; $\mathrm{Cb}$, flower; $\mathrm{Cc}$, flower, dissected. $\mathrm{D}$, A. laxisecunda (sect. Myriocrater): $\mathrm{Da}$, cincinnus; $\mathrm{Db}$, stamen and pistil of male flower; Dc, female flower, dissected; Dd, flower. A, D, spirit material, B, C, dried material. 
[Alpinia sect. Oligocincinnus K. Schum., Pflanzenr. Zing. 359 (1904) - p.p. excl. type.]

Inflorescence erect, unbranched. Bracts conspicuous, not always persistent. Flowers in upper half of cincinni sometimes functionally male (not observed in A. eubractea); calyx not deeply split unilaterally; base of labellum connate to the base of the filament into a distinct tube above the petals; free part of labellum deeply bilobed or entire; lateral staminodes present or not; stigma small, perhaps funnel-shaped; epigynous glands free from each other. Capsule spherical.

Type species: A. eubractea K. Schum., Pflanzenr. Zing. 353 (1904); R. M. Smith in Notes RBG Edinb. 40: 531, f.1 (1983). Figs 1Ad, 2G.

Other species: $A$. beamanii R. M. Smith, Fig. 1Ae; $A$. rufa Presl, Fig. 8B.

Distribution: Sulawesi, Borneo, the Philippines. Map 16.

The Philippine A. rufa and A. beamanii (Borneo) are very closely allied. A. eubractea deviates in the entire labellum, ecristate anther and more or less acute rather than long-cucullate dorsal petal.

Sect. Myriocrater K. Schum., Pflanzenr. Zing. 356 (1904); Burtt \& Smith in Notes RBG Edinb. 32: 29 (1972); R. M. Smith in op. cit., 35: 195 (1977).

Syn.: Alpinia sect. Monopleura K. Schum., Pflanzenr. Zing. 361 (1904).

Type: A. monopleura K. Schum.

[Alpinia sect. Dieramalpinia K. Schum. in Bot. Jahrb. 27: 272, 286 (1899)-p.p. excl. type.]

[Alpinia sect. Oligocincinnus K. Schum., Pflanzenr. Zing.357 (1904) - p.p. excl. type.]

Inflorescence often pendulous, sometimes with lateral branches at the base. Bracts absent or minute, rarely conspicuous and persistent; bracteoles tubular, telescoping. Cincinni sometimes secund on the main axis; all but the first or, rarely the second flower functionally male; calyx not deeply split unilaterally; labellum more or less oblong; lateral staminodes present; filament well formed; anther of hermaphrodite flower usually crested; stigma prominent, hard, glabrous; epigynous glands massive, splitting irregularly.

Type species: A. myriocratera K. Schum. in Bot. Jahrb. 27: (290) (1899) \& Pflanzenr. Zing. 356 (1904).

Other species: $A$. aenea Burtt \& Smith; $A$. biakensis R. M. Smith; $A$. celebica $\mathrm{K}$. Schum.; A. coeruleo-viridis K. Schum.; A. conferta Burtt \& Smith; A. edanoi R. M. Smith; A. eremochlamys K. Schum.; A. gigantea Bl.; A. laxisecunda Burtt \& Smith, Figs 1Af, 2D, 8D; A. monopleura K. Schum., Fig. 1Ag; A. novae-hibernica Burtt \& Smith; A. regia R. M. Smith; A. salamonensis Burtt \& Smith; A. unilateralis Burtt \& Smith; A. vulcanica Elmer.

Distribution: The Philippines, Sulawesi, the Moluccas, the Bismarck Archipelago (absent from the New Guinea mainland) and the Solomons. Map 17.

Valeton, although he did not publish his findings, was the first to observe the monoecism which is consistent throughout sect. Myriocrater. The section includes some of the largest known species of Alpinia, several of which may approach a height of $10 \mathrm{~m}$. 
Sect. Dieramalpinia K. Schum. in Bot. Jahrb. 27: 272, 286 (1899).

Syn.: Eriolopha Ridley in Hooker's Icon. Pl. 31: t.3067 (1916) \& Trans. Linn. Soc. Bot. 9: 217 (1916)-p.p. incl. type: E. flagellaris Ridley $=$ Alpinia flagellaris (Ridley) Loesener.

?Elmeria Ridley in Elmer, Lflts Philipp. Bot. 2: 603 (1909)non Elmera Rydb. (1905). Type: E. bifida Ridley = Alpinia paradoxa (Ridley) Loesener.

?Adelmeria Ridley in op. cit. 603. Type: $A$. bifida Ridley $=$ Alpinia paradoxa (Ridley) Loesener.

Alpinia sect. Oligocincinnus K. Schum., Pflanzenr. Zing. 359 (1904) - p.p. incl. lectotype (selected here): Alpinia strobilacea K. Schum.

?Alpinia sect. Cylindrobotrys K. Schum., op. cit. 356. Type: Alpinia cylindrocephala $\mathrm{K}$. Schum.

Alpinia sect. Eubractea subsect. Eustales Val. in Nova Guinea (Botanique) 8: 943 (1913). Type: A. eustales K. Schum. = ? A. papuana Scheffer.

[Alpinia sect. Eubractea K. Schum., Pflanzenr. Zing. 352 (1904) - p.p. excl. type.]

[Alpinia sect. Kolowratia (Presl) Loesener, Pflanzenfam. ed. 2 15a: 621 (1930)-p.p. excl. type.]

[Alpinia sect. Eubractea subsect. Kolowratia (Presl) Val. in Nova Guinea (Botanique) 8: 943 (1913) - p.p. excl. type.]

[Alpinia sect. Kolowratia subsect. Guillainia (Vieill.) Loesener Pflanzenfam. ed. 2, 15a: 621 - p.p. excl. type.]

[Alpinia sect. Kolowratia subsect. Eukolowratia Loesener op. cit. 622 - p.p. excl. type.]

Inflorescence often pendulous, unbranched. Bracts, almost without exception, large and often brightly coloured, sometimes hiding the main axis, always persistent. Calyx usually distinctly three-lobed, the lobes often elongate; labellum narrowly oblong to more or less triangular; lateral staminodes usually absent; anther more or less sessile (except in A. carolinensis), usually crested; stigma prominent, rigid, sometimes hairy; epigynous glands massive, splitting irregularly. Capsule usually spherical, occasionally ellipsoid.

Type species (selected here): A. oceanica Burkill in Proc. Cambr. Philos. Soc. 9: 93 (1896). Figs 1Aa, 2A.

Other species: $A$. arfakensis K. Schum.; A. bodenii R. M. Smith, Fig. 9c; A. calycodes Val.; A carinata Val.; A carolinensis Koidz., Figs 2c, 9D; ? A. chaunocolea K. Schum.; A. cylindrocephala K. Schum.; A. dasystachys Val.; A. densiflora K. Schum.; A. domatifera Val., Fig. 1Ab; A. euastra K. Schum.; A. flagellaris (Ridley) Loesener; ? A. gigantifolia (Elmer) R. M. Smith; A. gracillima Val.; A.jankowskii Val.; A.juliformis (Ridley) R. M. Smith; A. kiungensis R. M. Smith, Figs 2B, 9A; $A$. klossii (Ridley) R. M. Smith; A. leptostachya Val.; ? A. luteocarpa Elmer; A. manostachys Val.; A. (Guillainia) minor Ridley; A. multispicata (Ridley) Loesener; ? A. musaefolia Ridley; 

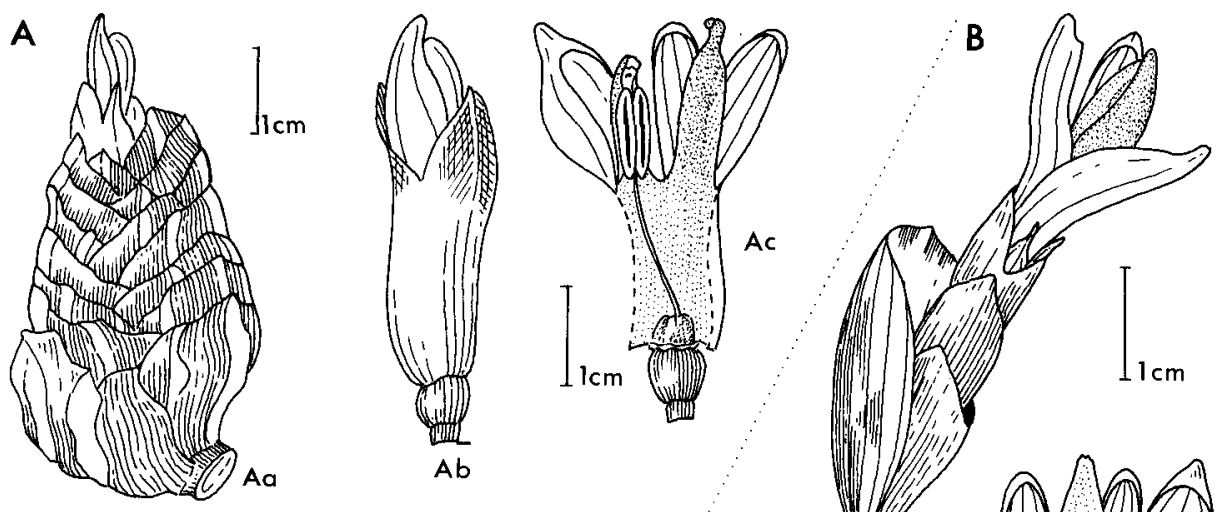

C
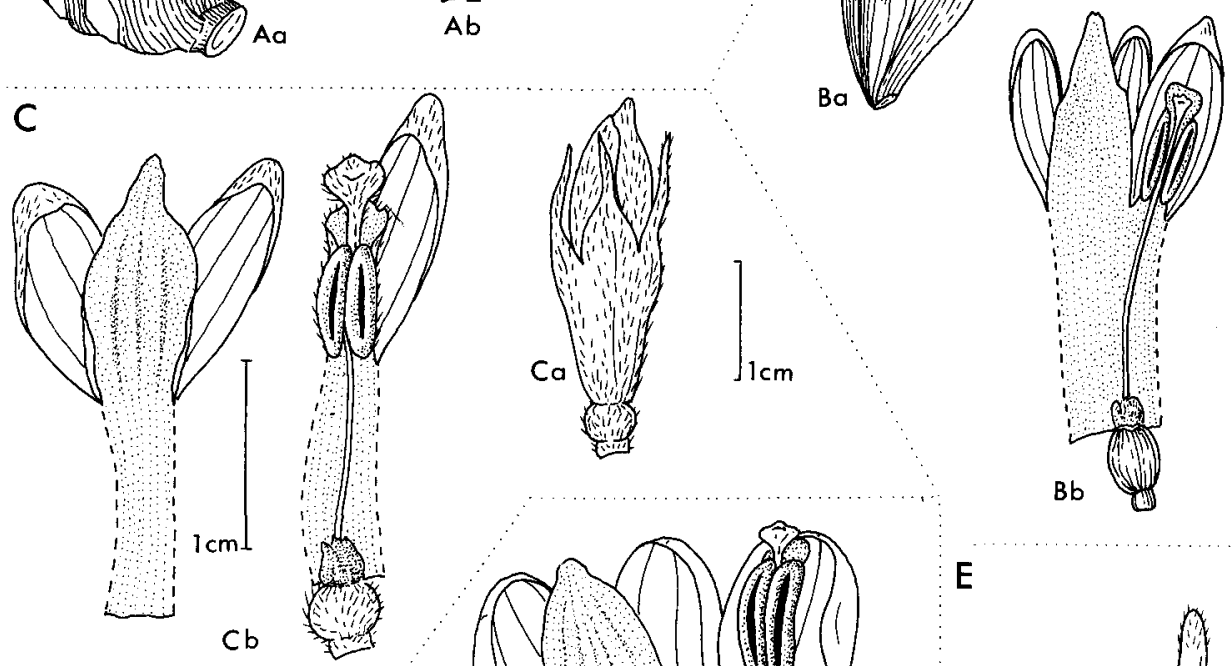

$\mathrm{Cb}$
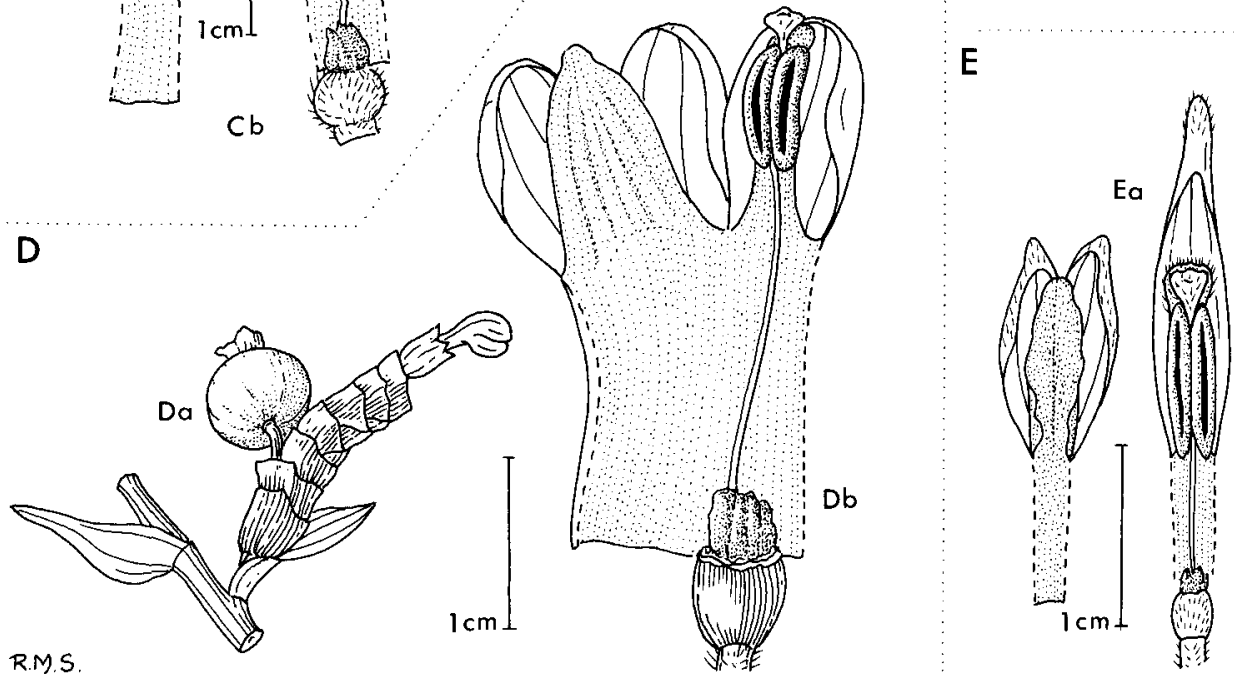

FIG. 9. Subgen. Dieramalpinia sect. Dieramalpinia. A, A. kiungensis: Aa, cincinnus showing tubular bracteoles (bract removed); Ab, flower, bracteole removed; Ac, flower, dissected. B, A. vittata: Ba, cincinnus with bract, showing tubular bracteoles; Bb, flower, dissected. C, A. bodenii (Eriolopha sericea): Ca, flower; $\mathrm{Cb}$, flower, dissected. $\mathrm{D}$, A carolinensis: Da, part of main axis showing bracts and a cincinnus; $\mathrm{Db}$, flower, dissected. E, A. platylopha: Ea, flower, dissected. A, B, D, spirit material, C, E from dried material. 
A. nutans (L.) Roscoe; ? A. oblonga (Merr.) Loesener; A. oligantha Val.; A. papuana Scheffer; ? A. paradoxa (Ridley) Loesener; $A$. pinetorum (Ridley) Loesener; $A$. platylopha (Ridley) Loesener, Fig. 9E; A. porphyrocarpa Ridley; A. rosacea Val.; $A$. schultzei Lauterb. ex Val.; A. sericiflora K. Schum.; A. strobilacea K. Schum.; A. superba (Ridley) Loesener; A. tristachya (Ridley) Loesener; $A$. valetoniana Loesener; A. vittata Bull, Fig. 9B, Plate 1A.

Distribution: New Guinea, the Bismarck Archipelago, Indonesia, the Carolines and the Philippines. Map 15.

The lectotype of subgenus Dieramalpinia, A. oceanica Burkill, is a well known species common at low altitudes throughout the Bismarck Archipelago; it is apparently absent from the New Guinea mainland. A closely related species (and one that may not be specifically distinct) is the variegated $A$. vittata which has been known in cultivation for over a century.

Many of the species listed above are badly known and no type material remains extant. Much of Eriolopha Ridley is placed here and some of these plants with their remote, 'catkin-like' cincinni (e.g. E. flagellaris) are superficially unlike the more tightly congested inflorescences of, say, A. kiungensis and A. superba. Nonetheless, as far as is known, all the species of sect. Dieramalpinia show conformity in labellum shape, stigma type and in the toothed calyx which dnes not snlit unilaterallv

As has been mentioned above, monoecism hi

Dieramalpinia. In some species, for instance $A$. tristacnya kidey, nowers nave been found with badly formed stigmas and shorter than normal styles. In all cases, however, dissection of the corresponding ovaries show ovules to be present.

\section{APPENDIX 1}

Alpinia Roxb. in Asiat. Res. 11: 350 (1810)-nom. cons.

Type species: Alpinia galanga (L.) Sw.

Frequently-used references in this Appendix have been abbreviated as follows:

Burtt \& Smith in Notes RBG Edinb. = Burtt \& Smith, Notes.

Elmer, A. in Leaflets Philipp. Bot. = Elmer, Lfts.

Loesener, L. Planzenfam. ed.2, 15a = Loesener (1930).

Schumann, K. in Bot. Jahrb. 27 = K. Schum. (1899).

, Pflanzenr. Zing. = K. Schum. (1904).

Smith, R. M. in Notes RBG Edinb. = Smith, Notes.

Valeton, T. in Nova Guinea (Botanique) $8=$ Val. (1913) in Bot. Jahrb. 52 = Val. (1914).

Note: Throughout this Appendix the herbarium location of type material is given only if this has been seen. 
POSITION OF THE SECTIONS AND SUBSECTIONS WITHIN THE SUBGENERA:

Subgen. ALPINIA

Sect. ALPINIA

Subsections: Alpinia

Presleia

Paniculatae

Cenolophon

Catimbium

Probolocalyx

Sect. DIDYMANTHUS

Sect. KOLOWRATIA

Sect. FAX

Sect. GUILLAINIA

Sect. ARCTIFLORAE

Sect. ALLUGHAS

Subsections: Allughas

Odontychium

Strobidia

Caeruleae

Subgen. DIERAMALPINIA

Sect. PYCNANTHUS

Subsections: Pycnanthus

Amomiceps

Sect. EUBRACTEA

Sect. MYRIOCRATER

Sect. DIERAMALPINIA

\section{SPECIES}

The following is a list of all species names employed in Alpinia, accepted names being given in bold.

abundiflora Burtt \& Smith, Notes 34: 179, f.5 (1979) (Amomum floribundum (Thwaites) Trimen) - Sri Lanka. Type: Thwaites 3374 (PDA, K). Sect. Fax.

acuminata R. M. Smith, see p. 63 (Rhynchanthus papuanus Gilli-non Alpinia papuana R. Scheffer) - New Guinea. Type: Gilli 440 (W). Sect. Pycnanthus subsect. Pycnanthus.

acrostachya Steudel, Nomencl. Bot. ed. 2, 1: 62 (1840) = Etlingera elatior (Jack) R. M. Smith.

aenea Burtt \& Smith, Notes 32: 42 (1972) — Indonesia. Type: Sands 595 (K, E). Sect. Myriocrater.

affinis Ridley in J. Bot. 24: 357 (1886) = Riedelia affinis (Ridley) K. Schum. africana Ridley in Bol. Soc. Brot. 6:203 (1887) = ? Renealmia grandiflora Bak.-non R. africana Benth. 
agiokuensis Hayata, Icon. P1. Formos. 9: 118 (1920)-Taiwan. Type: Hayata s.n. = A. japonica (Thunb.) Miq.

alba (Bl.) Dietr., Syn. Pl. 1: 45 (1839) (based on Elettaria alba Bl.- - non Alpinia alba (Retz.) Roscoe $(1807)=$ ? Etlingera sp.

alba (Retz.) Roscoe in Trans. Linn. Soc. 8: 346 (1807)-Malaysia. Type: König s.n. = A. galanga (L.) Sw.

alata Dietr., Syn. Pl. 1: 45 (1839)-China. = A. bracteata Roscoe (1814) - non Roxb. (1820).

albertisii K. Schum., $279(1899)=$ Riedelia albertisii K. Schum. albida (Elmer) Loesener, 620 (1930)-Philippines. Type: Elmer 15912 $(\mathrm{BM}, \mathrm{K})=\mathrm{A}$. oblonga $($ Merr.) Loesen.

albipurpurea (van Royen) R. M. Smith, see p. 64 (Kolowratia albipurpurea van Royen, Alp. Fl. New Guin. 2: 890, f.298, 1979)New Guinea. Type: van Balgooy 583 (L). Sect. Pycnanthus subsect. Pycnanthus.

allughas (Retz.) Roscoe in Trans. Linn. Soc. 8: 346 (1807)—Sri Lanka.

Type: König s.n. = A. nigra (Gärtner) B. L. Burtt.

(Adelmeria) alpina Elmer, Lflts 8: 2885 (1915)—Philippines. Syntypes:

Elmer 10642; 10534. Subgenus Dieramalpinia sect.?

angustifolia K. Schum., 279, f.2j (1899)-Borneo. Type: Beccari 3602

$(\mathrm{FIR})=$ A. glabra Ridley.

annabellae Ridley in J. Bot. 63: Suppl. 121 (1925) = Plagiostachys sp. probably P. uviformis (L.) Loesener.

antillarum Roemer \& Schultes, Syst. Veg. 1: 20 (1817) = Renealmia jamaicensis (Gärtner) Horan.

apoensis Elmer, Lflts, 8: 2888 (1915)—Philippines. Type: Elmer 11889

(BM, K, US - all veg). Imperfectly known species. Sect. ?

aquatica (Retz.) Roscoe in Trans. Linn. Soc. 8: 346 (1807)-Malaysia.

Type: König s.n., specimen lost (Type of Martensia Giseke). Sect. Alpinia subsect Presleia. Fig. 5f.

arctiflora F. Muell., Fragm. 8: 25 (1873)-Australia. Lectotype: Dallachy s.n. (MEL). Sect. Arctiflora. Fig. 6B.

arfakensis K. Schum., 296 (1899)—New Guinea. Type: Beccari s.n. Sect. Dieramalpinia.

argentea (Burtt \& Smith) R. M. Smith in Bot. J. Linn. Soc. 85: 69 (1982)-Borneo. Type: Burtt \& Martin B5166 (E). Sect.Alpinia subsect. Cenolophon. (Illustr., Notes 31: 213, f.12). Fig. 5E.

aromatica Aublet, Hist. Pl. Guiane 1: $3(1775)=$ Renealmia guianensis Maas.

aromatica Jacq., Fragm. Bot. 53, t.74, $75(1809)=$ Renealmia occidentalis (Sw.) Sweet. 
arundelliana (F. M. Bailey) K. Schum., 318 (1904)-Australia. Type: Bailey s.n.(K). Sect. Alpinia subsect. Caeruleae. (Illustr., Fl. Austr. 45: 30 f.26K-O).

assimilis Ridley in J. Str. Br. Roy. Asiat. Soc. 27: 166(1899)-Malaysia. Type: Ridley s.n. Sect. Alpinia subsect. Catimbium.

athroantha Val., 952, f.171 (1913) - New Guinea. Syntypes: Versteeg 1438 (L, K); von Römer 409 (L), 398, 470. Sect. Pycnanthus subsect Pycnanthus.

aurantiaca Ridley in J. Fed. Mal. States Mus. 4:78 (1909)--Malaysia. Type: Wallich $6575(\mathrm{~K})=$ A. rafflesiana Wall. ex Baker.

auriculata Roscoe, Monandr. Pl. Scitam., t. 74 (1825)-origin unknown. Type: Cult. Liverpool. ? = A. calcarata Roscoe. Sect. Alpinia subsect Catimbium.

babeldoabensis (Kaneh.) Hosok. Reference to combination not traced. Name listed by Fosberg, Sachet \& Oliver in Micronesia 20 (1987). Based on Languas babeldaobensis Kaneh. in Trans. Nat. Hist. Soc. Form. 25: 7 (1935)-Palau. Syntypes: Kanehira 321, 2295. = A. carolinensis Koidz.

bambusifolia Liang \& Fang in Acta Phytotax. Sin. 16: 77, f.1 (1978) China. Type: Fang Ding et al. 3-0211. Sect. Alpinia subsect. Alpinia. beamanii R. M. Smith, Notes 45: 345, f.1 (1989) - Borneo. Type: Beaman 8308 (E, K). Sect. Eubractea.

biakensis R. M. Smith, Notes 35: 205 (1977) - Bismarck Archipelago. Type: Kosterman \& Soegang 882 (L). Sect. Myriocrater.

bicalyculata Sessé \& Moç., Fl. Mex. ed. 1, 3 (1894) = Renealmia sp. bifida Warb. in Bot. Jahrb. 13: 275 (1891)—Oceania. Type: Warburg s.n. = A. galanga.

(Adelmeria) bifida (Ridley) Ridley in Elmer, Lflts 2: 603 (1909)-Philippines. Type: Elmer 7706 (BM, K) = A. paradoxa (Ridley) Loesener.

bilamellata Makino in Bot. Mag. Tokyo 16: 51 (1902) - Type: Tanaka s.n. Sect. Alpinia subsect. Alpinia. (Illustr.,Toyoda, Fl. Bonin Is. pl.104, 1981).

biligulata Val., 939, f.167B (1913)-New Guinea = Psychanthus biligulata (Val.) R. M. Smith in Edinb. J. Bot. 47: 81 (1990).

bisulcata Sessé \& Moç., F1. Mex. ed. 1, 3 (1894) = Renealmia sp.

blepharocalyx K. Schum., 334 (1904)—China. Type: Henry 11962 (K, E). Sect. Alpinia subsect. Catimbium. (Illustr., Fl. Reipubl. Pop. Sin. 16: f.28).

blumei Dietr., Syn. Pl. 1: 13 (1839)—Java. Type: Blume s.n. = A. javanica $\mathrm{Bl}$. 
blumei K. Schum., 282 (1899) - Java.—non A. blumei Dietr. (1839). Type: Blume s.n. = A. ludwigiana R. M. Smith.

bodenii R. M. Smith, see p. 64 (Eriolopha sericea Ridley-non Alpinia sericea Ridley (1914) - New Guinea. Type: Boden Kloss s.n.(BM, K). Sect. Dieramalpinia. Fig. 9C.

boia Seeman, Fl. Vit. 290, t.88 (1868) - Fiji. Type: Seeman 620 (K). Sect. Pycnanthus subsect. Pycnanthus. (Illustr., A. C. Smith, Fl. Vitien. Nov. 1: f.52, 1979). Fig. 8C.

boninsimensis Makino in Bot. Mag. Tokyo 16: 52 (1902)-Bonin Is. Type: Tanaka s.n. Sect. Alpinia subsect. Alpinia. (Illustr., Toyoda, Fl. Bonin Is. Pl. 94, 1981).

borneensis Val. ex Gagnep. in Bull. Soc. Bot. Fr. 51: 448 (1904)Borneo. Type: Cult. Bogor, originally from Borneo = A. nieuwenhuizii Val.

borraginoides K. Schum., 344, f.42,E,F (1904)—Burma. Type: Huk 55. Sect. Allughas subsect. Allughas.

brachypoda K. Schum., 298 (1899) = Plagiostachys strobilifera (Baker) Ridley.

brachyanthera Merr. in Philipp. J. Sci.,Bot. 10: 296(1915)—Philippines. Type: Weber 1571 (BM, K). Sect. Alpinia subsect Presleia.

bracteata Roscoe in Trans. Linn. Soc. 11: 281 (1814); Monandr. Pl. Scitam. t.70 (1826) - China. Type: Ic. Stanley. Sect. Alpinia subsect. Catimbium.

bracteata Roxb., Hort. Bengal 2 (1814)-nom. nud.; F1. Ind. 1: 61 (1820) -E Himalayas - non A. bracteata Roscoe (1814). Type: Cult. Calcutta (? BM). = A. blepharocalyx K. Schum.

branderhorstii Val., 941 (1913) = Psychanthus branderhorstii (Val.) R. M. Smith in Edinb. J. Bot. 47: 81 (1990).

brevilabris Presl, Reliq. Haenk. 1: 110 t.17 (1830)—Philippines. Type: Haenke s.n. Sect. Alpinia subsect. Presleia.

breviligulata Gagnep., Fl. Ind. Chin. 6: 88, f.9 (1809)—Vietnam. Type: Bon s.n. Sect. Alpinia subsect. Alpinia.

brevis Wu \& Senjen in Acta. Phytotax. Sin. 16: 36, f.9 (1978) - China. Type: Zuo \& Chen 43711. Sect. Alpinia subsect. Alpinia. breviscapa Poepp. \& Endl., Nov. Gen. et Spec. 2: t.135 (1838) - Icon. tantum, nom. inval. = Renealmia breviscapa Poepp. \& Endl. brevituba Val., 953 (1913) - New Guinea. Type: von Römer $1190=\mathbf{A}$. odontonema K. Schum.

burkillii M. R. Henderson in Gard. Bull. Str. Settl. 4: 55 (1927)-Malaysia. Type: Henderson SFN25080 (SING) = A. pahangensis Ridley. 
caerulea Bentham, Fl. Austr. 6: 265 (1873)-Australia. Syntype: Brown 5605 s.n. (BM). Sect. Allughas subsect. Caeruleae. (Illustr., Notes RBG Edinb. 38: 522, f.3C).

calcarata Roscoe in Trans. Linn. Soc. 8: 347 (1807)--India, China.

Type: Cult. Liverpool, no specimen extant. Sect. Alpinia subsect

Catimbium. (Illustr., Roscoe Monandr. t.68, 1824).

calycodes K. Schum., 295, f.10 (1899) - New Guinea. Type: Beccari 589. Sect. Dieramalpinia.

campanaria Ridley in J. Str. Br. Roy. Asiat. Soc.86: 308 (1922) - Malaysia. Type: Ridley s.n. (K). = A. javanica Bl.

cannifolium Ridley in J. Str. Br. Roy. Asiat. Soc. 32: 174 (1899)Malaysia. Type: Ridley s.n. $(\mathrm{K})$. = A. vitellinum var. cannifolium (Ridley) Holttum.

capitellata Jack, Mal. Misc., 2: n.7, 4 (1822)-Malaysia. Type: Jacks. s.n.. Sect. Allughas subsect. Allughas.

cardamomum (L.) Roxb. in Asiat. Res. 11: 356 (1810) = Elettaria cardamomum (L.) Maton.

cardamomum medium Roxb., F1. Ind. 1: $72(1820)=$ Amomum costatum (Roxb.) Baker.

caribea (Griseb.) O. Kuntze, Rev. Gen. 1: 690 (1891) = Renealmia pyramidalis (Lamarck) Maas.

caribea Gärtner, Fruct. Sem. Pl. 1: 36, t. 12 (1788) = Renealmia pyramidalis (Lamarck) Maas.

carinata Val., 945 (1913) - New Guinea. Syntypes: Versteeg 1271 (L), 1283 (L); Branderhorst 368 (L). Sect. Dieramalpinia. (Illustr., Notes RBG Edinb. 34: 162, f.3B).

carnea Griff., Not. Pl. Asiat. 3: 420 (1851)-Malaysia. Type: Griffith s.n. = A. galanga (L.) Sw.

carolinensis Koidz. in Bot. Mag. Tokyo 31: 233 (1917) - Caroline Is.

Type: Koidzumi s.n. Sect. Dieramalpinia. Fig. 9D.

caudata Gagnep. in Bull. Soc. Bot. Fr. 31: 446 (1904)-ascribed to Borneo ?. Type: Cult. Bogor. = A. romburghiana Val.

celebica K. Schum., 362 (1904)—Sulawesi. Type: Riedel s.n. (K). Sect. Myriocrater.

cernua Sims in Bot. Mag. 44: t. 1900 (1817)-E Indies. Type: Cult. J.

Walker $=$ A. calcarata Roscoe.

chaunocolea K. Schum., 292 (1899)—New Guinea. Type: Beccari 7.

Sect. Dieramalpinia.

chinensis auct. - non (Retz.) Roscoe $(1807)=$ A. suishaensis Hayata. chinensis (Retz.) Roscoe in Trans. Linn. Soc. 8: 346 (1807)-China.

Type: König s.n. Cult. Malaya-specimen lost. Identity uncertain. 
chinensis Vidal, Phan. Cuming. Philipp. 152 (1885); Rev. Pl. Vasc. Filip. 274 (1886)-Philippines-non A. chinensis (Retz.) Rosc. (1807) = A. cumingii $\mathrm{K}$. Schum.

chinghsiensis Fang, Fl. China 16: $80(1981)-$ China $=$ A. jingxiense Fang (orth. syn.)

chrysogynia (K. Schum.) K. Schum., 365 (1904) = ? Amomum sp.

chrysorachis K. Schum.,[ 283 (1899)—nom. nud.]; 337 (1904)—

Sulawesi. Type: Sarasin 829. Sect. Alpinia subsect. Catimbium.

coccinea (Bl.) Dietr., Syn. Pl. 1: 12 (1839) = Etlingera punicea (Roxb.)

R. M. Smith.

coeruleoviridis K. Schum.,[ 293, f.42H (1899)-nom. nud.]; 361

(1904) - Sulawesi. Type: Sarasin 829. Sect. Myriocrater.

colossea K. Schum., 289, f.3,j (1899)—New Guinea. Type: Beccari 192 = A. papuana R. Scheffer.

comosa Jacq., Coll. 4: $112(1870)=$ Costus comosus (Jacq.) Roscoe.

comosa Ridley in J. Str. Br. Roy. Asiat. Soc. 32: 170 (1899)-Malaysia.-non $A$. comosa Jacq. (1870). Type: Ridley $4443(\mathrm{~K})=$ A. oxymitrum K. Schum.

compta K. Schum., 277, f.2,G (1899) = Psychanthus comptus (K. Schum.) R. M. Smith in Edinb. J. Bot. 47: 79 (1990).

conchigera Griff., Not. Pl. Asiat. 3: 424, t.354 (1851) - Malaysia. Type: Griffith $5700(\mathrm{~K})$. Sect. Alpinia subsect Strobidia. (Illustr., Fl. Reipubl. Pop. Sin. f.32, 1981).

condensata Val., 953 (1913) - New Guinea. Syntypes: von Römer 1110, 1118. Imperfectly known species. (see Smith, Notes 36: 274, 1978).

conferta Burtt \& Smith, Notes 32: 40, f.2A (1972)—Solomons. Type: Corner 107 (K, E). Sect. Myriocrater.

congesta Elmer, Lflts 8: 2968 (1919) — Philippines. Type: Elmer 16144 (BM, K, L, US, all veg.). Sect. ? Kolowratia.

conglomerata R. M. Smith, Notes 36: 277, f.2A (1978)—New Guinea. Type: van Royen NGF18154 (LAE). Sect. Pycnanthus subsect. Pycnanthus.

copelandii Ridley in Philipp. J. Sci. 4: 184 (1909)—Philippines. Type: Copeland s.n.. Sect. Alpinia subsect. Catimbium.

cordylinoides Ridley in Trans. Linn. Soc. Bot. 9: 211 (1916) = Riedelia cordylinoides (Ridley) R. M. Smith, see p. 65.

coriacea Wu \& Senjen in Acta. Phytax. Sin. 16: 31, f.5 (1978)-China. Type: How 73508. Sect. Alpinia subsect. Alpinia. (Illustr., Fl. Reipubl. Pop. Sin. 16: f.24, 1981).

coriandriora Fang in Acta. Phytax. Sin. 16: 78, f.4 (1978) - China. Type: Fang 78908. Sect. Alpinia subsect. Alpinia. 
corneri (Holttum) R. M. Smith, see p. 65-Malaysia. Type: SFN30506 (SING, K, E). Sect. Alpinia subsect. Cenolophon. cornucervi Ridley in J. Str. Br. Roy. Asiat. Soc. 46: 243 (1906) - Borneo.

Type: Hewitt s.n. (K, SING) = A. aquatica (Retz.) Roscoe.

corollina K. Schum. in Schum. \& Lauterb., Fl. Deutsch. Sudsee 225:

$(1900)=$ Riedelia corollina (K. Schum.) Val.

costata Roxb., Pl. Coromand. 3: 48, t. 252 (1819) = Amomum costatum

(Roxb.) Baker.

cristata Griff., Not. Pl. Asiat. 3: 421 (1851) - Malaysia. Type: Griffith

s.n. = ? A. zerumbet (Pers.) Burtt \& Smith.

cristata Roxb. as listed by Schumann-typographical error =

Amomum costatum (Roxb.) Baker.

crocydocaly $x$ K. Schum., 281 (1899) = Plagiostachys crocydocalyx $(\mathrm{K}$.

Schum.) Burtt \& Smith.

cumingii K. Schum., 315 (1899)—Philippines. Type: Cuming 859 (BM,

K). Sect: Alpinia subsect Presleia.

cylindrocephala K. Schum.,[ 297 (1899)—nom. nud.]; 356, f.41,H,K

(1904) - Sulawesi. Type: Sarasin 1243. Sect. Dieramalpinia.

cylindrostachys K. Schum., 299 (1899) = Amomum coriaceum R. M.

Smith.

dasystachys Val., 946 (1913) - New Guinea. Syntypes: von Römer 1016,

1114 , 1157. Sect. Dieramalpinia (may = A. densiflora K. Schum., see Smith, Notes 34: 185, 1975).

decurva Ridley in J. Bot. 29: 357 (1866) = Riedelia decurva (Ridley) Val.

decurvata Baker in Hook. f., Fl. Brit. Ind. 6: 257 (1892) = Geostachys decurvata (Baker) Ridley.

decockii Val., 948, f.170B (1913)—New Guinea. Type: de Kock 1911.

Sect. Dieramalpinia.

densibracteata Wu \& Senjen in Acta. Phytax. Sin. 16: 32, f. 6 (1978)-

China. Type: Zeng 25332. Sect. Alpinia subsect. Alpinia. (Illustr., Fl. Reipubl. Pop. Sin. 16: f.24, 1981).

densiflora K. Schum., 292 (1899)—New Guinea. Type: Beccari 916. Sect. Dieramalpinia.

densiflora Gagnep. in Bull. Soc. Bot. Fr. 48: Ixxxviii (1902) - Vietnamnon $A$. densiflora K. Schum. (1899). Type: Bon s.n. = A. gagnepainia K. Schum.

densiflora (Urban) Mosc., Cat. Fl. Doming. 88 (1943) - non $A$. densi-

flora $\mathrm{K}$. Schum. = Renealmia densiflora Urban.

densispicata Hayata, Icon. Pl. Formos. 9: 119 (1920)-Taiwan. Type:

Sasaki s.n. = A. shimadai Hayata. 
denticulata (Ridley) Holttum in Gard. Bull. Sing. 13: 143 (1950)Malaysia. Type: Ridley s.n. (K). Sect. Allughas subsect. Odontychium. Fig. 7A.

diffissa Roscoe in Trans. Linn. Soc. 11: 281 (1815); Monandr. t.71 (1825)—China. Type: Ic. Stanley. Sect: Alpinia subsect. Catimbium. diracodes Loesener, $614(1930)=$ Etlingera elatior (Jack) R. M. Smith. divaricata Val., 950, f.170C (1913)-New Guinea. Syntypes: Versteeg 1657 (K); von Römer 853. Sect. Pycnanthus subsect. Pycnanthus. (Illustr., Notes RBG Edinb. 36: 282, f.3B).

diversifolia (Elmer) Elmer, Lftts, 8: 2991 (1919) —Philippines. Type: Elmer 8853. Imperfectly known species based on Vanoverbergia diversifolia Elmer.

dolichocephala Hayata, Icon. Pl. Formos. 9: 119(1920)—Taiwan. Type: Hayata s.n. Sect. Alpinia subsect. Catimbium.

domatifera Val., 955, f.172 (1913)-New Guinea. Type: Gjellerup 1022 (L). Sect. Dieramalpinia.

dyeri K. Schum., 349 (1904) - Samoa. Type: Whitmee 276. Imperfectly known species, see Christopherson in Bern. P. Bishop Mus. Bull. 128: 59 (1935). Probably sect. Pycnanthus subsect. Pycnanthus.

edanoi R. M. Smith, Notes 35: 200 (1977) — Sulawesi. Type: Edaño 7132 (L). Sect. Myriocrater.

elatior Jack, Malay. Misc. 2: 2 (1822) = Etlingera elatior (Jack) R. M. Smith.

elegans (Presl) K. Schum., 288 (1899)—Philippines. Type: Haenke s.n. Sect. Kolowratia. Fig. 4B.

elmeri R. M. Smith, see p. 64 (A. longipetiolata Elmer-1919, non Gagnep., 1909) - Philippines. Syntypes: Elmer 16167 (US), 16954 (BM, L). Sect. Alpinia subsect. Presleia.

elwesii Turrill in Bot. Mag. 142: t.8651 (1916) - Taiwan. Type: Hort. Elwes (K). Sect. Alpinia subsect. ? Cenolophon.

emaculata S. Q. Tong in Acta. Phytax. Sin. 27: 285, f.8 (1989)—China. Type: Tong \& Li 24900. Sect. Alpinia subsect. Catimbium. engleriana K. Schum. in Notizbl. Bot. Gart. Berlin.2: 102 (1898)-New Britain. Syntypes: Dahl 7; Naumann s.n. = A. oceanica Burkill. erecta Steudel, Nomencl. Bot. ed.2: $62(1840)=$ A. calcarata Roscoe. eremochlamys K. Schum.,[288, f.3,G (1899)—nom. nud.]; 362, f. 40,O,P (1904)-Sulawesi. Syntypes: Sarasin 412; Meyer s.n. Sect. Myriocrater.

(Kolowratia) eruciformis Ridley in Philipp. J. Sci. 4: 182 (1909) - Philippines. Type: Merrill 5258 (US). Material inadequate. ? sect. Kolowratia. 
euastra K. Schum., 296, f. 4,B (1899)-New Guinea. Type: Beccari 348.

Sect. Dieramalpinia.

eubractea K. Schum.,[ 289 (1899)-nom. nud.]; 353, f.41,G (1904)-

Sulawesi. Type: Sarasin 846 . Sect. Eubractea. (Illustr., Notes RBG Edinb. 40: 532, f.1, 1983).

eustales K. Schum., 288 (1899)-New Guinea. Type: Beccari $251=$ A. papuana R. Scheffer.

exaltata (L. f.) Roemer \& Schultes, Syst. 1: 21 (1817) = Renealmia alpina (Rottb.) Maas.

exostylis K. Schum., 314 (1904)-Borneo. Type: Korthals s.n. (L). = A. aquatica (Retz.) Roscoe.

fasciculata Steudel, Nomencl. Bot. ed.2, 1: 62 (1840) = ? Amomum aromaticum.

fax Burtt \& Smith, Notes 34: 177 (1975) (Amomum involucratum (Thwaites) Trimen)-Sri Lanka. Type: Thwaites 3019 (PDA, BM, K). Sect. Fax.

ferruginea Steudel, Nomenc1. Bot. ed.2, 1:62 (1840). Based on Elettaria mollis $\mathrm{B} 1 .=$ ? Etlingera sp.

fimbriata Gagnep. in Bull. Soc. Bot. Fr. 51: 447 (1904)--? Taiwan. Type: Cult. Bogor. = A. schumanniana Val.

flabellata Ridley in Philipp. J. Sci. 4: 188 (1909)--Philippines, Japan. Syntypes: Bureau Sci. 2718, 2871; Merrill 1878, 2226. Sect. Alpinia subsect. Presleia.

flagellaris (Ridley) Loesener, 622 (1930)-New Guinea. Type: Boden Kloss s.n. (BM, K). Sect. Dieramalpinia. Type of Eriolopha Ridley. (Illustr., Hooker's Icon. Pl. 31: t. 3067, 1916).

flava Ridley in J. Linn. Soc. Bot. 42: 163 (1914) - Borneo. Type: Gibbs $4011(\mathrm{BM}, \mathrm{K})=$ A. nieuwenhuizii Val.

flexistamen K. Schum., 281 (1899)—Borneo. Type: Beccari 1491 (FIR). = A. glabra Ridley.

floccosa Val., 940 (1913) = Psychanthus floccosus (Val.) R. M. Smith in Edinb. J. Bot. 47: 81 (1990).

floribunda K. Schum., 439 (1904) = Psychanthus floribundus (K. Schum.) R. M. Smith in Edinb. J. Bot. 47: 80 (1990).

fluviatilis Hayata, Icon. Pl. Formos. 5: 227 (1913)—Taiwan. Type: Hayata \& Sasaki s.n. = A. schumanniana Val.

foetens (Bl.) Dietr., Syn. PI. 1: 12 (1839) = Etlingera foetens (B1.) R. M. Smith.

formosana K. Schum., 283 (1899)-Taiwan. Syntypes: Warburg 9705, 10623, 10625. Sect. Alpinia subsect. Catimbium. 
foxworthyi Ridley in Philipp. J. Sci. 4: 189 (1909)-Philippines. Type: Foxworthy 772 (K). Sect. Alpinia subsect. Presleia.

fraseriana Oliver in Hooker's Icon. Pl. 16: t.1567 (1887)-Borneo.

Syntypes: Fraser s.n. (K); Burbidge s.n. = A. aquatica (Retz.) Roscoe.

fusiformis R. M. Smith, Notes 34: 156, f.2 (1975)-New Guinea. Type:

Womersley NGF17732 (LAE). Sect. Guillainia.

gagnepainii K. Schum. 342 (1904)—Vietnam.Type: Bon s.n. Sect. Alpinia subsect. Cenolophon.

galanga (L.) Sw., Obs. Bot. 6 (1791)-India. Type: no specimen at

LINN. Sect. Alpinia subsect. Alpinia. Type of Alpinia Roxb. (Illustr.

Notes 31: 187, f.3B, 1972; Fl. Reipubl. Pop. Sin. 16: f.21, 1981).

gigantea Bl., Enum. Pl. Jav. 59 (1827)-Moluccas. Type: Reinwardt s.n.

(L). Sect. Dieramalpinia.

gigantea F. Vill. in Blanco, Fl. Philipp. ed.3, nov. app. $225(1883)=\mathbf{A}$. elegans (Presl) K. Schum.

gigantifolia (Elmer) R. M. Smith, see p. 65 (Adelmeria gigantifolia Elmer)—Philippines. Syntypes: Elmer 14603, 16154. Sect. Dieramalpinia.

gjellerupii Val., 938, f.167A (1913) = Psychanthus gjellerupii (Val.) R. M. Smith in Edinb. J. Bot. 47: 80 (1990).

glabra Ridley in J. Str. Br. Roy. Asiat. Soc. 32: 168 (1899)-Borneo. Type: Haviland 444 (K). Sect. Alpinia subsect. Probolocalyx. (Illustr., Notes RBG Edinb. 42: 285 f.6, 1985). Fig. 5G.

glabrescens Ridley in Philipp. J. Sci. 4: 185 (1909)--Philippines. Type: Mearns 3141. Sect. Alpinia subsect. Catimbium.

globosa (Lour.) Horan., Prod. Monogr. Scitam. 34 (1862)-Vietnam.

Type: Loureiro s.n. Sect. Alpinia subsect. Alpinia.

gracilis Rolfe in J. Linn. Soc. 21: 316 (1884)—nom. nud.—Philippines = A. elegans (Presl) K. Schum.

gracillima Val., 948 (1913) - New Guinea. Syntypes: von Römer 763, 1108. Sect. Dieramalpinia.

graminea Ridley in Philipp. J. Sci. 4: 189 (1909) - Philippines. Type: Everett 7267. Sect. Alpinia subsect. Presleia.

graminifolia Fang \& Lo in Acta. Phytotax. Sin. 16: 78, f.2 (1978)-

China. Type: Lo 5070. May = A. officinarum Hance. Sect. Alpinia subsect. Cenolophon.

grandiceps Ridley in J. Str. Br. Roy. Asiat. Soc.50: 148 (1908)—Borneo.

Type: Hewitt s.n. (K). = A. capitellata Jack.

grandis K. Schum. in Notizbl. Bot. Gart. Berlin 2: 103 (1898)--

Bismarck Archipelago. Syntypes: Dahl s.n.; Naumann s.n.; Lauterbach $160=$ A. purpurata (Vieill.) K. Schum. 
granumparadisi Moon, Cat. Pl. Ceylon 1 (1824)--nom. nud. = Aframomum sp.

guandongensis Senjen \& Chen in Guihaia 8: 317 (1988)-China. Type: Senjen, Chen \& Fang 3722. Sect. Alpinia subsect. Alpinia.

guinanensis Fang \& Chen in Guihaia 2: 135, f.1 (1982) -China. Type: Chen et al. 2-287. Sect. Alpinia subsect. Catimbium.

haenkei Presl, Symb. Bot. 66, t. 43 (1832-33)-Philippines. Type: Haenke s.n. Sect. Alpinia subsect. Catimbium.

hageana R. M. Smith, Notes 36: 284, f.4A (1978)-New Guinea. Type: Stevens LAE50267 (E, LAE). Sect. Pycnanthus subsect. Pycnanthus. hainanensis K. Schum., 335 (1904)-Hainan. Type: Henry 8773 (K). Sect. Alpinia subsect. Catimbium.

hansenii R. M. Smith in Bot. J. Linn. Soc. 85: 70, f.17B (1982)-Borneo. Type: Hansen 439 (C). Sect. Alpinia subsect. Cenolophon.

havilandii K. Schum., 329 (1904) - Borneo. Type: Haviland 1233 (K). Sect. Alpinia subsect. Cenolophon. (Illustr., Notes RBG Edinb. 42: 280, 1985).

hellwigii K. Schum., 320 (1904) = Psychanthus hellwigii (K. Schum.)

R. M. Smith in Edinb. J. Bot. 47: 80 (1990).

hemsleyana K. Schum., 348 (1904)-Fiji. Type: Seeman $620=$ A. boia Seeman.

hemisphaerica (Bl.) Dietr., Syn. Pl. 1: $13(1839)=$ Etlingera hemisphaerica (Bl.) R. M. Smith.

henryi K. Schum., 335 (1904)—China. Type: Henry 8402 (K). Sect. Alpinia subsect. Catimbium.

hibinoi Masamune in Trans. Nat. Hist. Soc. Taiwan 33: 108 (1943)Taiwan. Type: Hibino s.n. Imperfectly known species.

himantoglossa Ridley in Trans. Linn. Soc. Bot. 9: 212 (1916)-New Guinea. Type: Boden Kloss s.n. (BM, K). Sect. Pycnanthus subsect. Pycnanthus.

hirsuta (Lour.) Horan., Prod. Monogr. Scitam. 34 (1862)-Vietnam. Type: ? Loureiro s.n. Imperfectly known species. Sect. ? Alpinia subsect. Catimbium.

hokutensis Hayata, Icon. Pl. Formos. 9: 120 (1920) - Taiwan. Type: Shimada s.n. = A. intermedia Gagnep.

hookeriana Val. in Bull. Inst. Bot. Buitenz. 20: 81 (1904). Type: Cult. Bogor. = A. latilabris Ridley.

horneana K. Schum., 349 (1904) - Fiji. Type: Horne s.n. Sect. Pycnanthus subsect. Pycnanthus. (Illustr., A. C. Smith, Fl. Vit. Nov. 1: f.3). hulstijnii Val. in Bull. Jard. Bot. Buitenz. sér 3, 5: 344, t.39 (1923)Sulawesi. Type: Cult. Bogor.(L). Sect. Alpinia subsect. Catimbium. 
humilis Teysm. \& Binn. in Naturk. Tijdschr. Ned.-Indië. 24: 327 (1862)-Java. Type: Teysmann s.n. = A. sumatrana (Miq.) $\mathrm{K}$. Schum.

humilis Vell., Fl. Flum. 1: t.4 (1827) = Renealmia sp.

hylandii R. M. Smith, Notes 38: 523, f.3A (1980)-Australia. Type: Hyland 9630 (QRS). Sect. Allughas subsect. Caeruleae. iboensis Val., 60, f.2,G-M (1914) = Psychanthus iboensis (Val.) R. M. Smith in Edinb. J. Bot. 47: 80 (1990).

illustris Ridley in Philipp. J. Sci. 4: 185 (1909)—Philippines. Type: Foxworthy 514 (K). Sect. Alpinia subsect. Catimbium.

inaequalis (Ridley) Loesener, 614 (1930)-New Guinea. Type: Boden Kloss s.n. (BM, K). Sect. Pycnanthus subsect. Pycnanthus. (Illustr., Notes RBG Edinb. 36: 282, f.3A, 1978).

intermedia Gagnep. in Bull. Soc. Bot. Fr. 48: Ixxxiii (1902) - Japan.

Type: Ferrie s.n. (K). Sect. Alpinia subsect. Alpinia.

involucrata Griff., Not. Pl. Asiat. 3: 422 (1851)-Malaysia. Type: Griffith s.n. $(\mathrm{K})=$ A. javanica $\mathrm{Bl}$.

iriomotensis Masamune in Trans. Nat. Hist. Soc. Formos. 24: 217 (1934)-Japan. Type: Masamune s.n. = A. flabellata Ridley.

jamaicensis Gärtner, Fruct. Sem Pl. 1: 36, t.12 (1788) = Renealmia jamaicensis (Gärtner) Horan.

jankowskii Val., 956 (1913)—New Guinea. Type: Jankowski 176. Sect. Dieramalpinia.

japonica (Thunb.) Miq. in Ann. Mus. Bot. Lugd.-Bat. 3: 140 (1867)Japan. Type: Thunberg s.n. Sect. Alpinia subsect. Alpinia.

javanica Bl.,Enum. Pl. Jav. 59 (1827)-Java. Type: Blume s.n. (L, K). Sect. Allughas subsect. Allughas. (Illustr., Henderson, Mal. Wild Fl., Monocot. f.87, 1954).

javanica (B1.) Dietr., Syn. Pl. 1: 13 (1839)—based on Diracodes javanica B1.-non A. javanica B1. (1827) = Etlingera elatior (Jack) R. M. Smith.

jinxiensis Fang in Acta. Phytotax. Sin. 18: 224 (1980)-China. Type: Lu \& Fang 23675. Sect. Alpinia subsect. Alpinia.

juliformis (Ridley) R. M. Smith, see p. 65-New Guinea. Type: Boden Kloss s.n. (BM, K). Sect. Dieramalpinia.

kainantensis Masamune in Trans. Nat. Hist. Soc. Taiwan 33: 28 (1943)-Hainan. Type: Masamune \& Fukuyama 174. Imperfectly known species.

katsumadai Hayata, Icon. Pl. Formos. 5: 224 (1915) - Hainan. Type:

Katsumada s.n. Sect. Alpinia subsect. Catimbium. (Illustr., Fl. Reipubl. Pop. Sin. 16: f.30, 1981). 
kawakamii Hayata, Icon. Pl. Formos. 5: 222 (1915)—Taiwan. Type: Kawakami 4917 = A. copelandii Ridley.

kelugensis Hayata, Icon. Pl. Formos. 5: 227, f.79C (1915)-Taiwan $=$ A. intermedia Gagnep.

kermesina Ridley in Trans. Linn. Soc. Bot. 9: 214 (1916) — New Guinea.

Type: Boden Kloss s.n. $(\mathrm{K})=$ A. divaricata Val.

kiungensis R. M. Smith, Notes 34: 163, f.3A (1975) - New Guinea.

Type: Streimann \& Lelean NGF34126 (E, LAE). Sect. Dieramalpinia.

kiushiana Kitamura in Bot. Mag. Tokyo 14: 37 (1946) —Japan. Type: Tashiro s.n. Sect. Alpinia subsect. Alpinia.

klossii (Ridley) R. M. Smith, see p. 65-New Guinea. Type: Boden Kloss s.n. (BM). Sect. Dieramalpinia.

koidzumiana Kitamura in Bot. Mag. Tokyo 14: 36 (1946) -Japan.

Type: Koidzumi s.n. = A. flabellata Ridley.

korthalsii K. Schum., 327 (1904)—Borneo. Syntypes: Beccari 3557; Motley $234(\mathrm{~K})$. = A. mutica Roxb.

koshüensis Hayata, Icon. Pl. Formos. 5: 227 (1915) - Taiwan. Type: Kato s.n. = A. formosana K. Schum.

kumatake Makino in Bot. Mag. Tokyo 16: 49 (1902) -Japan. Type: Matsumura \& Okubo, cult. Japan, originally from China $=\mathbf{A}$. formosana K. Schum.

kusshakuensis Hayata, Icon. P1. Formos. 9: 121 (1920)-Taiwan. Type:

Hayata s.n. = A. uraiensis Hayata.

kwangsiensis Wu \& Senjen in Acta. Phytotax. Sin. 16: 35, f.9 (1978)-

China. Type: Liang \& T.L. Wu 32226. Sect. Alpinia subsect. Catimbium. (Illustr., Fl. Reipubl. Pop. Sin. 16: 29, 1981).

laosensis Gagnep. in Bull. Soc. Bot. Fr. 43: 133 (1906)-Laos. Type:

Pavie s.n. $=$ A. conchigera Griff.

latifolia Willd. ex Korn. in Bull. Soc. Nat. Mosc. 23: 1: 130 (1862)= Calathea latifolia

latilabris Ridley in J. Str. Br. Roy. Asiat. Soc. 32: 168 (1899)—Malaysia. Type: Cult. Calcutta. Sect. Alpinia subsect. Catimbium. (Illustr., Bot. Mag. t.6908 - as A. mutica, 1886).

lauterbachii Val., 65, f.3M-R (1914)—Bismarck Archipelago. Type: Peekel 127. Sect. Alpinia subsect. Presleia.

laxiflora Gagnep. in Bull. Soc. Bot. Fr. 48: 1xxxviii (1901) - Vietnam. Syntypes: Talmy 233; Lefevre 209, 121; Chaper s.n. $($ Borneo) $=$ A. mutica Roxb.

laxisecunda Burtt \& Smith, Notes 32: 39, f.1 B (1972)—Solomons. Type: Sore 2316 (K, E). Sect. Myriocrater. Fig. 8D. 
leptosolena K. Schum., 312 (1904) = Leptosolena haenkei Presl.

leptostachya Val., 947, f.170A (1913)-New Guinea. Type: Versteeg 1642 (L). Sect. Dieramalpinia.

ligulata K. Schum., 275 (1899) - Borneo. Syntypes: Beccari 987 (FIR), 1307(FIR). Sect. Alpinia subsect. Paniculatae. (Illustr., Notes RBG Edinb. 42: 277, f.4A, 1985).

linguiformis Roxb., Fl. Ind. 1:73(1820) = Etlingera linguiformis (Roxb.) R. M. Smith.

longipetiolata Elmer, Lflts 8 : 2969 (1919)—Philippines-non A. longipetiolata Gagnep. (1906). Syntypes: Elmer 1617 (US), 16954 $(\mathrm{BML}) .=$ A. elmeri R. M. Smith.

longipetiolata Gagnep. in Bull. Soc. Bot. Fr. 53: 134 (1906) = Renealmia $\mathrm{sp.}$

longilora Ridley in J. Bot. 51: 247 (1913) = Burbidgea longilora (Ridley) R. M. Smith.

ludwigiana R. M. Smith, see p. 64 (A. blumei K. Schum.- - non Dietr.) Java. Type: Blume. s.n. (L). Sect Guillainia.

luteocarpa Elmer, Lfits 10: 3803 (1939)-Philippines. Type: Elmer 17926 (BM, K, L - all veg., US poor). Sect. ? Dieramalpinia.

maclurei Merr. in Philipp. J. Sci. 21: 338 (1922)-Hainan. Type: Maclure 8963 (K, E). Sect. Alpinia subsect. Alpinia. (Illustr., Fl. Reipubl. Pop. Sin. 16: f.23, 1981).

macrantha R. Scheffer in Ann. Jard. Buitenz. 1: $56(1876)=$ Riedelia macrantha (R. Scheffer) K. Schum.

macrantha Poepp. \& Endl., Nov. Gen. et Spec.2: t.134 (1838) Icon. tantum, nom. inval. = Renealmia alpina (Rottb.) Maas.

macrocarpa Gagnep. in Bull. Soc. Bot. Fr. 53: 136(1906) - Kampuchea. Syntypes: Pierre s.n. (K, veg.); Hahn s.n.; Godefroy s.n. = A. oxymitra K. Schum.

macrocarpa Val., 944, f.169A (1913)-New Guinea-non A. macrocarpa Gagnep. (1906). Syntypes: Versteeg 1270 (L, K); Branderhorst 356 (L); von Römer $538=$ A. valetoniana Loesener.

macrocephala K. Schum., 350 (1904)—Fiji. Type: Horne s.n. (K). Sect. Pycnanthus subsect. Amomiceps. (Illustr., A. C. Smith, Fl. Vitien. Nov. 1: f. 56,57, 1979).

macrocephala Hayata, Icon. Pl. Formos. 5: 223 (1915) - Taiwan — non A. macrocephala Gagnep. (1904). Syntypes: Hayata \& Sasaki s.n.; Hayata \& Takeo s.n. = A. sessiliflora Kitamura.

macropycnantha Val.,940, f.168A (1914). = Psychanthus macropycnanthus (Val.) R. M. Smith in Edinb. J. Bot. 47: 81 (1990). 
macroscaphis K. Schum., 284 (1899)-Philippines. Type: Warburg 1888. Sect. Alpinia subsect. ? Catimbium.

macrostemon K. Schum., 297 (1899) = Geocharis macrostemon (K.

Schum.) Holttum.

macrostephana (Baker) Ridley in J. Str. Br. Roy. As. Soc. 32: 175 (1899)-Malaysia. Type: King's collector 1905 (SING, K). Sect. Alpinia subsect. Cenolophon.

macroura K. Schum. in Bot. Tidsskr. 24: 268 (1902)—Thailand. Type:

Schmidt 642 (K, veg). Sect. Alpinia subsect. Catimbium.

maculata Roscoe in Trans. Linn. Soc. 8: 347 (1907). Type: Cult. Liverpool. Imperfectly known species.

magnifica Roscoe, Monandr. Pl. Scitam. t.75 (1828) = Etlingera elatior (Jack) R. M. Smith.

malaccensis (Burm.) Roscoe in Trans. Linn. Soc. 8: 345 (1808) —Indo-

Malaysian. Type: Rumphius, Herb. Amboin. 5: t. 71 (1747). Sect.

Alpinia subsect. Catimbium. (Illustr., Bot. Reg. t.328, 1818).

malaccensis Presl, Reliq. Haenk. 1: 110 (1830)-Philippines-non $A$. malaccensis (Burm.) Roscoe (1808). Type: Haenke s.n. = A. haenkei Presl.

mannii Baker in Hook. f., Fl.Brit. Ind. 6: 253 (1892)—Andamans. Type:

King's collector 390 (K). Sect. Allughas subsect. ? Strobidia.

manostachys Val., 949 (1913) - New Guinea. Type: von Römer 1153.

Sect. Dieramalpinia.

martinii R. M. Smith, Notes 42: 281, f.5C (1985)—Borneo. Type: Burtt \& Martin B4989 (E). Sect. Alpinia subsect. Cenolophon.

media Sprengel, Syst. Veg. 1: 14 (1825) = Amomum costatum Roxb. mediomaculata Hayata, Icon. Pl. Formos. 9: 122 (1920)-Taiwan.

Type: Hayata s.n. = A. shimadai Hayata.

melanocarpa (Teysm. \& Binn.) Ridley in J. Str. Br. Roy. As. Soc. 32:

163 (1899) - Malaysia, Indonesia. Type: Cult. Bogor = A. aquatica

(Retz.) Roscoe.

melichroa K. Schum., 364 (1904) = ? Amomum.

mesana Horan., Prodr. Monogr. Scitam. 27 (1862)—sphalm. neesiana

$=$ Zingiber macrostachyum Dalziel.

mesanthera Hayata, Icon. Pl. Formos. 5: 225 (1915)-Taiwan. Type:

Hayata s.n. = ? A. zerumbet (Pers.) Burtt \& Smith.

microlophon Ridley in J. Str. Br. Roy. Asiat. Soc. 54: 58 (1909)-

Borneo. Type: Brookes s.n. (K). Sect. Allughas subsect. Allughas.

(Guillainia) minor Ridley in Trans. Linn. Soc. Bot. 9: 216 (1916)—New

Guinea-non A. minor (B1.) Dietr. (1839). Type: Boden Kloss s.n.

(BM, K). Sect. Dieramalpinia. It has already been pointed out 
(Smith, 1975: 164) that the type of Guillainia minor (and the original description) is unsatisfactory. The species may be synonymous with either $A$. rosacea Val. or $A$. superba (Ridley) Loesen.

minor (Bl.) Dietr., Syn. Pl. 1: 12 (1839) = Hornstedtia minor (B1.) K. Schum.

minuta (Bl.) Dietr., Syn. Pl. 1: 12 (1839) = ? Globba orixensis Roxb.

modesta (F. Muell.) K. Schum., 318 (1904)-Australia. Type: Dallachy s.n. (MEL). Sect. Allughas subsect. Caeruleae. Fig. 7C.

mollis Dietr., Syn. Pl. 1: 12 (1839)—non A. mollis Presl (1830) =? Etlingera.

mollis Presl, Reliq. Haenk. 110 (1830) - Philippines. Type: Haenke s.n. Doubtful species. Type not found ( $f i d e \mathrm{~K}$. Schum.).

mollissima Ridley, Fl. Mal. 5: 339 (1925)—Malaysia. Type: SFN10838

(SING, K). Sect. Alpinia subsect. Cenolophon.

moluccana Gagnep. in Bull. Soc. Bot. Fr. 48: xc (1902)-Moluccas.

Type: Gaudichaud $101=$ A. nutans (L.) Roscoe.

monopleura K. Schum.,[287 (1899) —nom. nud.]; 361 (1904) — Sulawesi.

Type: Sarasin 219. Sect. Myriocrater.

multicaulis Roemer \& Schultes, Syst. Veg. 1: 21 (1817) = Renealmia guianensis Maas.

multispicata (Ridley) Loesener, 622 (1930) - New Guinea. Type: Boden Kloss s.n. (BM). Sect. Dieramalpinia.

murdochii Ridley in J. Str. Br. Roy. Asiat. Soc. 44: 196 (1905)—Malaysia. Type: Murdoch s.n. (SING, K). Sect. Allughas subsect. Allughas. musaefolia Ridley in Elmer, Lflts 2: 604 (1909). Philippines. Type: Elmer 9539 (BM, K, L). Sect. ? Myriocrater.

mutica Roxb. in Asiat. Res.11: 354 (1810)-Malaysià. Type. Cult. Calcutta, originally collected from Penang. Sect. Alpinia subsect. Catimbium. (Illustr., Roscoe Monandr. t.69, 1824).

myriocratera K. Schum., 290, f.3K (1899)--Moluccas. Type: Beccari s.n. Sect. Myriocrater.

nanchuanensis Z. Y. Zhu in Guihaia 7: 295, f.1 (1987)—China. Type: Zhang 183. Sect. ? Alpinia subsect. Alpinia.

neesiana Graham, Cat. Pl. Bombay 207 (1839)—nom. nud. = Zingiber macrostachyum Dalziel.

neragaimae Gilli in Ann. Naturh. Mus. Wien 84: 43 (1983) = Psychanthus neragaimae (Gilli) R. M. Smith in Edinb. J. Bot. 47: 81 (1990).

nidus-vespae A. \& J. Raynal in Adansonia 13: 63, f.2 (1977)-New Hebrides. Type: Raynal 16379 (E). Sect. Pycnanthus subsect. Pycnanthus. 
nigra (Gärtner) B. L. Burtt, Notes 35: 213 (1977)—Sri Lanka, India. Type: Cardamomum zeylanicum fructu rotundo nigro, in caulium summitate Hermann, Parad. Bot. 320, 1689. No specimen in Herb. Hermann. Sect Allughas subsect. Allughas. (Illustr., Fl. Reipubl. Pop. Sin. 16: f.31, 1981).

nieuwenhuizii Val. in Bull. Inst. Buitenz. 20: 86 (1904).—Borneo. Type: Nieuwenhuis s.n. Sect. Alpinia subsect. Paniculatae. (Illustr., Ic. Bog. 2: t.192, 1906).

nimmonii Graham, Cat. Pl. Bombay 206 (1839) = Zingiber nimmonii Dalziel.

nobilis Ridley in J. Str. Br. Roy. Asiat. Soc. 32: 169 (1899) — Malaysia. Type: Ridley 4617 (K). = A. malaccensis var. nobilis (Ridley) Holttum.

novae-hiberniae Burtt \& Smith, Notes 32: 38 (1972)-New Ireland. Type: Sands 857 (K, E). Sect. Myriocrater.

novae-pommeraniae K. Schum., 285, f.3C (1899) - New Britain. Syntypes: Dahl 131; Warburg 16158. Sect. Alpinia subsect. Catimbium. Fig. 5B.

nutans (L.) Roscoe in Smith, Exot. Bot. 2: 93 (1805)-Moluccas. Type: Globba silvestris major Rumph., Herb. Amb. 6: 140 t. 62,63, (1750) in explicatione tab. t. 63, sphalmate pro Globba silvestris minor distincta habetur. Sect. Dieramalpinia. (Illustr., Notes RBG Edinb. 34: pl.7, 1975).

nutans K. Schum., Fl. Kais. Wilh. Land 28 (1889)-Mioko, Kerawara - non $A$. nutans (L.) Rosc. Type: Hollrung $844=$ A. oceanica Burkill

oblonga (Merr.) Loesener, 620 (1930)-Philippines. Type: Vanoverherg 3108. Sect. ? Dieramalpinia.

oblongifolia Hayata, Icon. Pl. Formos. 5: 215 (1915)-Taiwan. Type: ? Hayata s.n. = A. intermedia Gagnep.

occidentalis Sw., Prodr. $2(1788)=$ Renealmia occidentalis (Sw.) Sweet.

oceanica Burkill in Proc. Camb. Phil. Soc. 9: 2, 93 (1895)—New Britain. Type: Hollrung 844 (K). Sect. Dieramalpinia. (Illustr., Notes RBG Edinb. 34: 168, f.4, 1975).

odontonema K. Schum. in Schum. \& Lauterb., Fl. Deutsch. Schutzgeb. Nachtr. 95 (1905) - Bismarck Archipelago. Type: Schlechter 1395. Sect. Pycnanthus subsect. Pycnanthus. (Illustr., Notes RBG Edinb. 36: 278 f. 1A, 1978).

officinarum Hance in J. Linn. Soc. 13: 6 (1873)-Hainan. Type: Hance 16866 (K). Sect. Alpinia subsect. Cenolophon. (Illustr., Bot. Mag. t.6995, 1888). 
oligantha Val., 957 (1913) — New Guinea. Type: Versteeg 1656. Sect. Dieramalpinia.

orchiodes K. Schum., $278(1899)=$ Riedelia orchiodes (K. Schum.) Val. orthostachys K. Schum.,[ 281 (1899)—nom. nud.]; 330 (1904)—

Sulawesi. Type: Sarasin 687. Sect. Alpinia subsect. Cenolophon.

oxymitra K. Schum. in Bot. Tidsskr. 24: 268 (1902) - Thailand. Type:

Schmidt s.n. Sect. Alpinia subsect. Cenolophon.

oxyphylla Miq. in J. Bot. Neerl. 1:93 (1861) — China. Type: Herb. Krone

(U, photo K). Sect. Alpinia subsect. Cenolophon. (Illustr., Fl. Reipubl.

Pop. Sin. 16: f.33, 1-3, 1981).

pacoseroca Jacq., Fragm. 54, t. 17 (1809) = Renealmia alpina (Rottb.)

Maas.

padacanca Val. in Bull. Jard. Bot. Buitenz. sér.3, 5: 344 (1923)-

Sulawesi. Type: Bequin 988. Sect. Alpinia subsect. Cenolophon.

pahangensis Ridley in J. Fed. Mal. States Mus. 10: 154 (1920)-Malay-

sia. Type: Evans s.n. (K). Sect. Allughas subsect. Allughas, Fig. 7D.

pallida (Bl.) Dietr., Syn. Pl. 1: 12 (1839) = Etlingera solaris (B1.) R. M.

Smith.

paludosa (B1.) Dietr., Syn. Pl. 1: 12 (1839) = Hornstedtia paludosa (B1.)

K. Schum.

papilionacea K. Schum., Fl. Kais. Wilh. Land 29 (1889); 278, t.2H

$(1899)=$ Psychanthus papilionaceus (K. Schum.) R. M. Smith in

Edinb. J. Bot. 47: 80 (1990).

papuana R. Scheffer in Ann. Jard. Bot. Buitenz. 1: 56 (1876) - New

Guinea. Type: Teysmann s.n. Sect Dieramalpinia.

paradoxa (Ridley) Loesener, 620 (1930)—Philippines. Type: Elmer 6629

(K). Sect. ? Dieramalpinia.

parksii (Gillespie) A. C. Smith in Sargentia 1: 7 (1942)—Fiji. Type:

Parks 20379. Sect. Pycnanthus subsect. Pycnanthus. (Illustr., A. C.

Smith, Fl. Vitien. Nov. 1: f.54, 1979).

parviftora Rolfe in J.Linn. Soc.21: $316(1884)=$ Plagiostachys sp.

pauciflora (Griseb. ex Peters.) O. Kuntze, Rev. Gen. 1: (1891) = Rene-

almia jamaicensis (Gärtner) Horan.

pectinata Ridley in Holth., Blumea 5: 168 (1942)—nom. nud.-Talaud

Is. Syntypes: $\operatorname{Lam} 2585(\mathrm{~L}, \mathrm{~K}), 2808 .=$ A. eremochlamys K. Schum. pedicellata Val., 60, f.2,A-F (1914) = Psychanthus pedicellatus (Val.)

R. M. Smith in Edinb. J. Bot. 47: 80 (1990).

peekelii Val., 62, f.3A-G (1914) = Psychanthus peekelii (Val.) R. M.

Smith in Edinb. J. Bot. 47: 80 (1990).

pelecystyla $\mathrm{K}$. Schum., 277, f.2F (1899) = Psychanthus pelecystylus $(\mathrm{K}$.

Schum.) R. M. Smith in Edinb. J. Bot. 47: 81 (1990). 
(Languas) pendula Quisumb. \& Merr. in Philipp. J. Sci. 37: 138 (1928)Philippines. Type: Ramos 43328. Sect. ?

penduliflora Ridley in Elmer, Lflts 2: 517 (1909)—Philippines. Type: Elmer 7288 (K). Sect. ? Dieramalpinia.

pennicellata Roscoe in Trans. Linn. Soc. 9: 280 (1814); Monandr., t.72 (1827)-China. Type: Ic. Stanley. Sect. Alpinia subsect. Catimbium.

petiolata Baker in Hook. f., Fl. Brit. Ind. 6: 255 (1892)-Malaysia. Type: King's collector 6357 (SING, K). Sect. Alpinia subsect. Cenolophon.

philippensis Ridley in Bull. Bur. Gov. Lab. Philipp. Islands 35: 86 (1905) - Philippines. Syntypes: Barnes 144 (K); Borden 1203; Elmer 6089 = A. haenkei Presl.

phoenicia Kamphoevener ex Kurz in J. Asiat. Soc. Bengal 45: 154 (1844) - nom. nud. - Nicobars = ? A. mannii K. Schum.

pininga (Bl.) Dietr., Syn. Pl. 1: $12(1839)=$ Hornstedtia pininga $(\mathrm{Bl}$.) Val.

pinetorum (Ridley) Loesener, 620 (1930)—Philippines. Type: Elmer 8548 (K). Sect. ? Dieramalpinia.

pinnanensis Wu \& Senjen in Acta. Phytotax. Sin. 15: 34, f.8 (1978)China. Type: Wang 5298. Sect. Alpinia subsect. Alpinia. (Illustr., Fl. Reipubl. Pop. Sin. 16: f.25,1-4, 1981).

(Languas) pintatubensis Elmer, Lfits, 9: 3225(1934)—Philippines. Type: Elmer 22058 (BM). Described from fruiting material and considered by Elmer to be close to A. flabellata Ridley (sect. Alpinia subsect. Presleia). Since the character of the labellum cannot be checked, no new combination has been made.

platychilus K. Schum.,334 (1904) - China. Type: Henry 12227 (K, E). Sect. Alpinia subsect Catimbium.

platylopha (Ridley) Loesener, 622 (1930)-New Guinea. Type: Boden Kloss s.n. (BM). Sect. Dieramalpinia.

platynema K. Schum., 438 (1904) = Psychanthus platyneus (K. Schum.) R. M. Smith in Edinb. J. Bot. 47: 82 (1990).

plectophylla K. Schum, 273, f.2A (1899) = Riedelia macrantha (Scheff.) K. Schum.

plumieri Krause in Beih. Bot. Centralblatt 32. 2:338(1914) = Renealmia pyramidalis (Lam.) Maas.

polyantha Fang in Acta. Phytotax. Sin. 16: 78, f.3 (1978) - China. Type:

Fang et al. 33298. Sect. Alpinia subsect. Alpinia.

polycarpa K. Schum., 298 (1899) = Amomum polycarpum (K. Schum.)

R. M. Smith. 
porphyrea R. M. Smith, Notes 36: 287, f.5A (1978)-New Guinea. Type: Kalkman 6262 (L). Sect. Pycnanthus subsect. Pycnanthus.

porphyrocarpa Ridley in Trans. Linn. Soc. Bot. 9: 231 (1916)-New Guinea. Type: Boden Kloss s.n. (BM, K). Sect. Dieramalpinia. presliana Steudel, Nomencl. Bot. ed 2, 1:62 (1840) = Renealmia cernua (Sw. ex Roemer \& Schultes) Macbride.

pricei Hayata, Icon. Pl. Formos. 5: 219 (1915)-Taiwan. Type: Price 1912. Sect. Alpinia subsect. Cenolophon.

psilogyna Fang in Acta. Phytotax. Sin. 16: 78, f.5 (1978) - China. Type: Wei \& Fang 32310. Sect. Didymanthus.

pterocalyx K. Schum., $332(1904)=$ Riedelia pterocalyx (K. Schum.) Val.

pterocarpa K. Schum., 332 (1904) = Psychanthus pterocarpus (K.

Schum.) R. M. Smith in Edinb. J. Bot. 47: 82 (1990).

ptychanthera K. Schum., 280 (1899) - Borneo. Type: Beccari 2450

(FIR). Sect. Alpinia subsect. Cenolophon.

pubiflora K. Schum., 313 (1904)—Philippines. Type: Barclay s.n. (K). Sect. Alpinia subsect. Presleia.

pulchella (K. Schum.) K. Schum., 276, f.2E (1899)-New Guinea. Type: Hollrung 368. Sect. Alpinia subsect. Presleia.

pulcherrima Ridley in J. Fed. Mal. States. Mus. 4: 79 (1909) - Malaysia. Type: Ridley $13850(\mathrm{~K})$. Sect. Alpinia subsect. Cenolophon.

pulchra (Warb.) K. Schum., 348 (1904)—New Guinea. Type: Warburg

s.n. Type of Hellwigia Warb. Sect. Pycnanthus subsect. Pycnanthus. (Illustr., Notes RBG Edinb. 36: 290 f.6A, 1978).

pumila Hook. f.in Bot. Mag. 111: t.6832 (1885)—China. Type: Ford s.n. (K, BM). Sect. Didymanthus. Fig. 6A.

punicea Roxb., Fl. Ind. 1: $71(1820)=$ Etlingera punicea (Roxb.) R. M. Smith.

purpurata (Vieill.) K. Schum., 323 (1904)-Melanesia. Type: Vieillard 1360. Sect. Guillainia. (Illustr., Notes RBG Edinb. 34: f.1, 1975). Fig. 6C.

pyramidata Bl., Enum. Pl. Java 58 (1830)—Java. Type: Blume s.n. =

A. galanga (L.) Sw.

quadriloba Ridley in Kew Bull. 90 (1926) - Sumatra. Type: Boden Kloss $14724(\mathrm{~K})=$ A. aquatica (Retz.) Roscoe.

racemigera $\mathrm{F}$. Muell., Fragm. 8: $27(1827)=$ Psychanthus racemiger $(\mathrm{F}$.

Muell.) R. M. Smith in Edinb. J. Bot. 47: 82 (1990).

racemosa $\mathrm{L}$., Sp. Pl. 1: 2 (1753) = Renealmia pyramidalis (Lam.) Maas. racemosa Sw., Observ. Bot. 4 (1791) = Renealmia jamaicensis (Gärtner)

Horan. 
rafflesiana Wall. ex Baker in Hooker's Icon. Pl. 20: t.1963 (1891)-Malaysia. Type: Wallich 6575 (K). Sect. Allughas subsect. Allughas. rechingeri Gagnep. in Bull. Soc. Bot. Fr. 55: 432 (1908)-Solomons.

Type: $T$. \& K. Rechinger $3859=$ A. pulchra (Warb.) K. Schum.

regia R. M. Smith, Notes 35: 203 (1977) - New Guinea. Type: Beguin 1234 (L). Sect. Myriocrater.

renealmia Sm. in Rees, Cyclop. 39 (77): 14 (1818) = Renealmia alpina

(Rottb.) Maas.

reticosa Ridley in J. Str. Br. Roy. Asiat. Soc. 46: 243 (1906)-Borneo.

Type: Ridley s.n. $(\mathrm{K})=$ A. ligulata K. Schum.

rheedii Wight, Icon. Pl. Ind. Orient t.2026 (1853)-Malabar. Type:

Wight s.n. = A. galanga (L.) Sw.

rigida Ridley in Trans. Linn. Soc. Bot. 9: 216 (1916) - New Guinea.

Type: Boden Kloss s.n. (BM). Sect. Pycnanthus subsect. Pycnanthus.

The same species is also described (op. cit.) under Eriolopha rigida

Ridley. (Illustr., Notes RBG Edinb. 36: 282 f.3C, 1978).

roemeri Val., 941 (1913) = Psychanthus roemeri (Val.) R. M. Smith in

Edinb. J. Bot. 47: 82 (1990).

rolfei K. Schum.,368 (1904) = Plagiostachys rolfei (K. Schum.) Ridley. romblonensis Elmer, Lflts 8: 2889 (1915)--Philippines. Type: Elmer 12050 (L). Sect. Alpinia subsect. Presleia.

romburghiana Val. in Bull. Inst. Buitenz. 20: 83 (1904)-Malay Archipelago. Type: Cult. Bogor (L). Sect. Alpinia subsect. Catimbium. (Illustr., Ic. Bog. 2: t. 193, 1906).

rosacea Val., 945, f.169B (1913)-New Guinea. Syntypes: Versteeg 1227 (K), 1655 (L, K); Branderhorst 333. Sect. Dieramalpinia.

roscoeana Steudel, Nomencl. Bot. ed. 2, 1: 63 (1840) a renaming of $A$. bracteata Roscoe-non Roxb.

rosea Elmer, Lflts 8: 2890 (1915)_-Philippines. Type: Elmer 12509 (L).

Sect. Alpinia subsect. Presleia.

rosella Ridley in J. Str. Br. Roy. Asiat. Soc. 32: 164 (1899)-Borneo.

Type: Hose s.n. $(\mathrm{K})=$ A. aquatica (Retz.) Rosc.

roxburghii Sweet, Hort. Brit. ed.1, 390 (1827) —Ind. Or. = A. bracteata Roscoe.

rubella Ridley in Bot. Jahrb. 44: 529 (1910)—Borneo. Type: Winkler 3095. = A. aquatica (Retz.) Roscoe.

(Cenolophon) rubrum Bl.-Sulawesi--Type: Reinwardt s.n., specimen

lost. Type of Cenolophon Bl., not sect. Cenolophon K. Schum. = Alpinia rubricaulis K. Schum.

rubra (Bl.) Dietr., Syn. Pl. 1: 12 (1839) = Hornstedtia rubra (Bl.) Val. rubricaulis K. Schum.,[281 (1899)—nom. nud.]; 330 (1904)-Sulawesi. 
Type: Sarasin 202. Sect. Alpinia subsect. Cenolophon (Illustr., Notes RBG Edinb. 34: pl.3,4, 1975 as Cenolophon rubrum).

rubromaculata S. Q. Tong in Acta. Phytotax. Sin. 27: 284, f.7 (1989)-

China. Type: Tong \& Li 24892. Sect. Alpinia subsect. Catimbium.

rufa (Presl) K. Schum., 293 (1899)-Philippines. Type: Haenke s.n. Sect. Eubractea. Fig. 8B.

rufescens K. Schum., 322 (1904)—Sri Lanka. Type: Thwaites 3732 (PDA, K, BM). Sect. Fax.

ruiziana Steudel, Nomencl. Bot. ed 2, $63(1840)=$ Renealmia racemosa Poepp. \& Endl.

salamonensis Burtt \& Smith, Notes 32: 41, f.2B (1972)-Solomons.

Type: Corner 143 (K, E). Sect. Myriocrater.

samoensis Reinecke in Bot. Jahrb. 25: 597, f.10 (1898)-Samoa. Type:

Reinecke 301. Sect. Pycnanthus subsect. Pycnanthus.

sanderae Sander in Gard. Chron. 33: 245 (1903)—New Guinea. Type:

Cult. Ghent $=$ A. vittata Bull.

sasakii Hayata, Icon. Pl. Formos. 5: 220 (1915)—Taiwan. Type: Sasaki s.n. = A. pricei Hayata.

satsumensis Gagnep. in Bull. Soc. Bot. Fr. 4: 247 (1902)-Japan. Type:

Cult., Exposition de 1889. = A. formosana K. Schum.

scabra (Bl.) Baker in Hook. f., Fl. Brit. Ind. 6: 256 (1892)-Indonesia.

Type: Blume s.n. Sect. Alpinia subsect. Presleia.

schlechteri K. Schum., 438 (1904) = Psychanthus schlechteri $(\mathrm{K}$.

Schum.) R. M. Smith in Edinb. J. Bot. 47: 80 (1990).

schultzei Lauterb. ex Val. in Bot. Jahrb. 52: 69 (1914) - New Guinea.

Type: Schultze 270. Sect. Dieramalpinia.

schumanniana Val. in Bull. Inst. Buitenz. 20: 84 (1904) - Taiwan. Type:

Cult. Bogor. Sect. Alpinia subsect. Catimbium.

(Languas) scorpoidea Quisumb. \& Merr. in Philipp. J. Sci. 37: 139 (1928)-Philippines. Type: Ramos \& Edano (K). Probably sect. Dieramalpinia. Labellum not described, no flowers on $\mathrm{K}$ material.

scyphonema K. Schum., 438 (1904) = Psychanthus scyphonemus (K.

Schum.) R. M. Smith in Edinb. J. Bot. 47: 80 (1990).

secunda Baker in Hook. f., Fl. Brit. Ind. 6: 257 (1892) = Geostachys secunda (Baker) Holttum.

secundiflora Ridley in J. Str. Br. Roy. Asiat. Soc. 32: 165 (1899) = Geocharis secundiflora (Ridley) Holttum.

seimundii Ridley in J. Str. Br. Roy. Asiat. Soc. 86: 309 (1922) — Malaysia. Type: Seimund s.n. (K). Sect. Allughas subsect. Allughas. Fig. 7 B. 
sericea Ridley in J. Linn. Soc. 42: 163 (1914)—Borneo. Type: Gibbs $3025(\mathrm{BM}, \mathrm{K})=\mathbf{A}$. latilabris Ridley.

(Eriolopha) sericea Ridley in Trans. Linn. Soc. Bot. 9: 221 (1916)New Guinea-non A. sericea Ridley (1914). Type: Boden Kloss s.n. $(\mathrm{BM}, \mathrm{K})=$ A. bodenii R. M. Smith.

sericiflora K. Schum., 294 (1899)-Bismarck Archipelago. Type: Beccari 7. Sect. Dieramalpinia.

serrulata Willd. ex Steudel Nomencl. Bot. ed. 2, 1: 63 (1840) = Renealmia sp.

sessiliflora Kitamura in Bot. Mag. Tokyo 54: 39 (1946) - A. macrocephala Hayata non K. Schum.-Taiwan. Syntypes: Hayata \& Sasaki s.n.; Hayata \& Takeo s.n. Sect. Alpinia subsect. Catimbium. sessilis König in Retz., Obs. Bot. 3: 64 (1783) = Kaempferia galanga L.

seticalyx (Ridley) Loesener, 620 (1930)-New Guinea. Type: Boden Kloss s.n. $(\mathrm{K})=$ A. strobilacea K. Schum.

shimadai Hayata, Icon. Pl. Formos. 5: 219 (1915) - Taiwan. Syntypes: Shimada s.n.; Sasaki s.n. Sect. Alpinia subsect. ? Cenolophon.

siamensis K. Schum., 357 (1904)—Thailand. Type: Schomburgk 123 (K). Sect. Allughas subsect. Strobidia.

sibuyanensis Elmer, Lflts 8: 2891 (1915)—Philippines. Type: Elmer 12316 (BM, K, L, all fruiting). Sect. Alpinia subsect. Presleia. silvicola Britton in Bull. Torr. Bot. Cl. 48: 329 (1922) = Renealmia thyrsoidea (Ruiz \& Pav.) Poepp. \& Endl.

simsii Gasp., Obsv. Boccodifalc. 4: (1833). Type: Cult. Real Orto Botanico Boccadifalco Palermo $=$ A. calcarata Roscoe.

singuliflora R. M. Smith, Notes 36: 277, f.1B (1978)-New Guinea.

Type: Croft et al LAE 60850 (E, LAE). Sect. Pycnanthus subsect. Pycnanthus.

solaris (Bl.) Dietr., Syn. Pl. 1:12 (1839) = Etlingera solaris (Bl.) R. M. Smith.

speciosa (Bl.) Dietr., Syn. Pl. 1: 13 (1839) = Etlingera elatior (Jack) R.

M. Smith.

speciosa (Wendl.) K. Schum., 339 (1904) - China - non A. speciosa

Dietr. (1839). Type: Wendl., Sert. Hannov. 4: 3, t.19 (1798) = A. zerumbet (Pers.) Burtt \& Smith.

spicata Jacq., Select. Stirp. Amer. Hist. t.1 (1763) = Costus spicatus (Jacq.) Sw.

spicata Presl, Reliq. Haenk. 1: 356 (1830) —non $A$. spicata Jacq. (1763)

$=$ Renealmia cernua (Sw. ex Roemer \& Schultes) Macbride.

spicata Roxb. in Asiat. Res. 11: 356 (1810); Fl. Ind. 1: 68 (1820)- 
Sumatra-non A. spicata Jacq. (1763). Type: Cult. Calcutta. Imperfectly known species. ? = A. calcarata Roscoe.

spiralis Jacq., Pl. Hort. Schoenbr. 1: $1(1797)=$ Costus spiralis (Jacq.)

Roscoe.

squarrosa Gilli in Ann. Naturh. Mus. Wien. 84: 44 (1983)-New

Guinea. Type: Gilli $534(\mathrm{~W})=$ A. stenobracteolata R. M. Smith.

stachyoides Hance in J. Linn. Soc. 13: 126 (1873) - China. Type: Hance

1231 (K). Sect. Alpinia subsect. Alpinia. Fig. 5C.

stapfiana K. Schum., 347 (1904)—Solomons. Type: Guppy $103(\mathrm{~K})=$ A. pulchra (Warb.) K. Schum.

stenobracteolata R. M. Smith, Notes 36: 287, f.6B (1978) - New Guinea.

Type: Millar NGF37800 (LAE). Sect. Pycnanthus subsect. Pycnanthus. Fig. 8A.

stenostachys K. Schum, 289 (1899); emend. Val. in Bot. Jahrb. 52: 67

(1914) - New Guinea. Type: Schlechter 17082 [?] = ? Psychanthus.

striatum Link, Enum. Hort. Berol Alt. 1: 5 (1821) = Amomum compactum [Sol. ex] Maton.

strobilacea K. Schum., 295 (1899)—New Guinea. Type: Beccari 552.

Sect. Dieramalpinia.

strobilifera Baker in Kew Bull. 225 (1898) = Plagiostachys strobilifera

(Baker) Ridley.

strobilifera Poepp. \& Endl., Nov. Gen. et Spec. 11: t.136 (1838) Icon. tantum, nom. invalid. = Renealmia cernua (Swartz ex Roemer \& Schultes) Macbride.

strobiliformis Wu \& Senjen in Acta. Phytotax. Sin. 16: 33, f.7 (1978)-

China. Type: Chang 12575. Sect. Alpinia subsect. Alpinia. (Illustr., Fl. Reipubl. Pop. Sin. 16: f.25,5-6, 1981).

subfusicarpa Elmer, Lflts 8: 2892 (1915)-Philippines. Type: Elmer 10506 (BM, K, L, US). Imperfectly known species.

submutica K. Schum., 280 (1899) —? Java. Type: Teysmann 2040. Imperfectly known species; see Burtt \& Smith, Notes 34: 111 (1975) and Kooders, Exkurs.-Fl. Java 1: 334 (1911).

subspicata Val., 65, f.3H-L (1914) - New Guinea. Type: Schlechter 16990. Sect. Alpinia subsect. Presleia.

subverticillata Val., 950 (1913) - New Guinea. Syntypes: Versteeg 1606 (K), 1416 (L). Sect. Pycnanthus subsect. Pycnanthus. (Illustr., Notes RBG Edinb. 36: 288, f.5C, 1978).

suishaensis Hayata, Icon. Pl. Formos. 9: 123 (1920)-Taiwan. Type: Hayata s.n. (A. chinensis auctt-non (Retz.) Rosc.). Sect. Alpinia subsect. Alpinia. (Illustr., Hayata, Icon. Pl. Formos. 5: 217 f.79f,g, as Alpinia sp.) 
sumatrana K. Schum., 291 (1899)-Sumatra. Type: Teysmann 4436 (K). Sect. Allughas subsect. Strobidia.

superba (Ridley) Loesener 622 (1930) - New Guinea. Type: Boden Kloss s.n. (BM, K). Sect. Dieramalpinia.

takaminei Masamune in Trans. Nat. Hist. Soc. Formos. 29: 57 (1939)

Japan. Type:? Takamine s.n. = ? A.intermedia Gagnep. (see Walker,

Fl. Okinawa \& S Ryukyu 328, 1976).

tarakoensis Masamune, Short Fl. Formos. 280 (1936) n.v.-Taiwan.

Type: ? = A. pricei Hayata.

tamacuensis R. M. Smith in Bot. J. Linn. Soc. 85: 71, f.17C (1982)-

Borneo. Type: Argent \& Coppins 1180 (E). Sect. Alpinia subsect.

Cenolophon.

tephrochlamys Lauterb. \& Schum., Fl. Schutzgeb. Südsee 226 (1900).

= Psychanthus tephrochlamys (Lauterb. \& Schum.) R. M. Smith in

Edinb. J. Bot. 47: 82 (1990).

thyrsoidea Steudel, Nomencl. Bot. ed. 2, 1: (1840) = Renealmia thyr-

soidea (Ruiz \& Pav.) Poepp. \& Endl.

tomentosa (B1.) Dietr., Syn. Pl. 1: 12 (1839) = Hornstedtia tomentosa (Bl.) Bakh. f.

tonkinensis Gagnep. in Bull. Soc. Bot. Fr. 48 (1902)-Vietnam. Type: Bon 5094. Sect. Alpinia subsect. Alpinia.

tonrokuensis Hayata, Icon. Pl. Formos. 9: 123 (1920) - Taiwan. Type:

Hayata s.n. Imperfectly known species (see Fl. Taiwan 840, 1978).

trachyascus K. Schum., 336 (1904)-Philippines. Type: Warburg 14584.

Sect. Alpinia subsect. ? Catimbium.

trichocalyx Val., 63 (1914) = Psychanthus trichocalyx (Val.) R. M.

Smith in Edinb. J. Bot. 47: 82 (1990).

tricolor Sander in Illustr. Wiener Gartenzeit. 28: 263 (1903); Gard.

Chron. 33: 245. Solomons. Type: Cult. Ghent. = A. vittata Bull.

tristachya (Ridley) Loesener, 622 (1930)_New Guinea. Type: Boden Kloss s.n. (BM, K). Sect. Dieramalpinia.

tubulata Ker Gawl. in Bot. Reg. t.777 (1824) = Renealmia alpina (Rottb.) Maas.

unilateralis Burtt \& Smith, Notes 32: 39, f.1B (1972)-Solomons. Type:

Corner 106 (K, E). Sect. Myriocrater.

uraiensis Hayata, Icon. Pl. Formos. 5: 224 (1915)-Taiwan. Type:

Shimada s.n. Sect. Alpinia subsect. Catimbium.

uviformis (L.) Horan., Prodr. Monogr. Scitam. 35 (1862) = Plagiostachys uviformis (L.) Loesen.

valetoniana Loesener, 622 (1930)-New Guinea. Syntypes: Versteeg 1270 (L, K); Branderhorst 365 (L); von Römer 538 (A. macrocarpa Val. non Gagnep.). Sect. Dieramalpinia. 
vanoverbergii Merr. in Philipp. J. Sci. 7: 75 (1912)-Philippines. Type: Vanoverberg 573 (K). Sect. Kolowratia. Fig. 4A.

velveta $R$. M. Smith, see p. 63 (Kolowratia velutina van Royen, 1979 non A. velutina Ridley ,1921) - New Guinea. Type: Brass 30553 (L). Sect. Pycnanthus subsect. Pycnanthus.

velutina Ridley in J. Nat. Hist. Soc. Siam 4: 123 (1921) - Vietnam. Type: Boden Kloss s.n. (BM). Sect. Alpinia subsect. Alpinia. May $=$ A. breviligulata Gagnep. var. compacta Gagnep.

(Kolowratia) velutina van Royen, Alp. Fl. New Guin. 2: 887, f.297 (1979) - non A. velutina Ridley-New Guinea. Type: Brass 30553 $(\mathrm{L})=$ A. velveta $\mathrm{R}$. M. Smith.

ventricosa (Griseb.) O. Kuntze, Rev. Gen. 1: 690 (1891) = Renealmia jamaicensis (Gärtner) Horan.

versicolor K. Schum.,[280 (1899)-nom. nud.]; 332, f.39Q (1904)Sulawesi. Syntypes: Warburg 15735; Sarasin 202. Sect. Alpinia subsect. Cenolophon.

viridiflora Griff., Not. Pl. Asiat. 3: 420, 423 (1851)-Malaysia. Type: Griffith s.n. = A. galanga (L.) Sw.

vitellina (Lindley) Ridley in J. Str. Br. Roy. Asiat. Soc.32: 173 (1899)Malaysia. Type: Cult. R.H.S.Gdns. Sect. Alpinia subsect. Cenolophon. (Illustr., Bot. Reg. t.52, 1847).

vitiensis Seeman, Fl. Vit. 290, t.87 (1868)-Fiji. Type: Seeman 621 (K). Sect. Pycnanthus subsect. Pycnanthus. (Illustr., A. C. Smith, Fl. Vitien. Nov. f.55, 1971).

vittata Bull, Cat. no 83: 4 (1873)—Polynesia. Type: Micholtz s.n.-no specimen. Sect. Dieramalpinia. Fig. 9B.

vulcanica Elmer, Lflts 8: 2971 (1919)—Philippines. Type: Elmer 16168. Sect. Myriocrater.

walang (Bl.) Dietr., Syn. Pl. 1: 13 (1839) = Etlingera walang (Bl.) R. M. Smith.

warburgii K. Schum.,[281 (1899)-nom. nud.]; 330 (1904)-Sulawesi. Type: Warburg 15763. Sect. Alpinia subsect. Cenolophon.

wenzlii Merr. in Philipp. J. Sci. 9: 353 (1914)—Philippines. Type: Wenzl 623 (BM). Sect. Alpinia subsect. Presleia.

werneri Lauterb. ex Val., 69 (1914) - New Guinea. Syntypes: Werner 170; Schlechter 17564 (K). Sect. Pycnanthus subsect. Pycnanthus. (Illustr., Notes RBG Edinb. 36: 288, f.5B, 1978).

womerslyi R. M. Smith, Notes 36: 285, f.4B (1978)-New Guinea. Type: Womersley et al. NGF37286 (LAE). Sect. Pycnanthus subsect Pycnanthus.

wrayi King ex Baker in Hook. f., Fl. Brit. Ind, 6: 252 (1892)—Malaysia. $=$ A. vitellina (Lindley) Ridley. 
zerumbet (Pers.) Burtt \& Smith, Notes 31: 204, f.10 (1972)-China. Type: Wendl., Sert. Hannov. 4: 3, t. 19 (1798). Sect. Alpinia subsect. Catimbium. (Illustr., Fl. Reipubl. Pop. Sin. 16: f.27, 1981).

zingiberina Hook. f. in Bot. Mag. 113: t. 6944 (1887) - Thailand. Type: Cult. Kew $(\mathrm{K})=$ A. galanga $(\mathrm{L}$.) $\mathrm{Sw}$.

\section{APPENDIX 2 \\ Key to the Terminally-Flowered Genera of Tribe AlpineaE \\ 1. Neotropical and African plants Renealmia \\ - Asiatic plants 2}

2. Leaves cordate to subsagittate; lip connate intramarginally to the base of the much elongated Globba-like filament (Burma, $\mathrm{N}$ Thailand)

Pommereschea

- Leaves and lip not as above

3. Inflorescence breaking through the leaf sheaths laterally just above ground level, often mucilaginous; lip not showy Plagiostachys

- Inflorescence rarely breaking through the leaf sheaths laterally; if so then towards the apex of the well-developed stem, never mucilaginous and lip showy

4. Lip reduced to a minute triangular appendage (Sino-Burmese) Rhynchanthus

- Lip well formed 5

5. Petals strap-shaped, lip held erect encircling the exserted filament (Burma) Stadiochilus

- Petals never strap-shaped, the dorsal one usually \pm hooded; lip sometimes erect, if so then filament not exserted

6. Flowers to $12 \mathrm{~cm}$ long; corolla tube very slender, exserted from the calyx for more than half its length (Philippines) _ Leptosolena

- Flowers not exceeding $6 \mathrm{~cm}$; corolla tube rarely long exserted from the calyx

7. Lip much shorter than the petals and joined to the filament into a short tube at the base, free part held erect; bracteoles absent (Borneo) Burbidgea

- Lip usually exceeding or \pm the same length as the petals, if shorter and held erect then plants with tubular bracteoles 8

8. Lip cup-shaped; stigma small, geniculate (New Guinea, Australia) Psychanthus

- Lip horizontal, pendulous, convolute or erect, never cup-shaped; stigma various

9. Calyx falling with the flower (New Guinea) Riedelia

- Calyx at least partially persistent on fruit Alpinia 


\section{ImPORTANT NeW SynONymy in Alpinia}

A. suishaensis Hayata, Icon. P1. Formos. 9: 123 (1920).

Type: Taiwan; Suisha, Holisha, Musha, Hayata s.n. (n.v.).

Syn.: A. chinensis auct. non (Retz.) Roscoe in Trans. Linn. Soc. 8: 346 (1807).

A. sp. Hayata, Icon. Pl. Formos. 5: 217 (1915).

The identity of $A$. chinensis (Retz.) Roscoe remains problematic. It was based on a plant collected by König from Malaya, said to have been cultivated in Chinese gardens for medicinal use. König's specimens were lost at sea but lengthy descriptions of his plants were published (Retz., Obs. Bot. 3: 65, 1783). That of his 'Languas chinensis, Malaya Sina Languas, ...'-later validated by Retzius (Heritiera chinensis Retz., Obs. Bot. 6, 1791) has points in common with both $A$. calcarata Roscoe and A. officinarum Hance but fits neither conclusively.

Bentham was in error in applying Retzius' epithet to his Hong Kong plants; Schumann realized this, although he did not alter the name and placed 'Languas chinensis', inexplicably, in synonymy under $A$. allughas ( $=A$. nigra (Gärtner) B. L. Burtt). Since then $A$. chinensis (Retz.) Roscoe has been misapplied by various authors, including the recent Flora of China where $A$. suishaensis is given as a synonym. Although I have not seen the type, there is good reason to believe that $A$. suishaensis is the correct name for Bentham's and for Schumann's plant. It is a very smallflowered species, of delicate habit (plants from Hong Kong are in cultivation at Edinburgh), closest to $A$. intermedia Gagnep., with which it shares a more or less similar distribution. A. intermedia is a much more robust species with leaves up to $8 \mathrm{~cm}$ wide (those of $A$. suishaensis do not exceed $3.5 \mathrm{~mm}$ ), and correspondingly larger flowers with a shortly unguiculate, rather than sessile labellum.

\section{New Names in Alpinia}

Alpinia acuminata R. M. Smith, nom. nov.

Type: Papua New Guinea, W Highlands, wood between Laiagan and Kandep, 3100m, 11 ii 1974, Gilli $440(\mathrm{~W})$.

Syn.: Rhynchanthus papuanus Gilli in Ann. Naturh. Mus. Wien 84: 46 (1983)-non Alpinia papuana R. Scheffer (1876).

Alpinia velveta $R$. M. Smith, nom. nov.

Type: Papua New Guinea, Mt Wilhelm, E slopes, 3000m, Brass 30553 (L).

Syn.: Kolowratia velutina van Royen in Alpine Fl. New Guinea 2: 887, t.297 (1979) — non Alpinia velutina Ridley (1921).

Both $A$. acuminata and $A$. velveta belong to the well-defined Alpinia sect. Pycnanthus subsect. Pycranthus and are most closely allied $10 A$. singulifora $R$. M. Smith. 
Alpinia ludwigiana R. M. Smith, nom. nov.

Type: Java, without precise locality, Blume s.n. (L).

Syn.: Hellenia bracteata Bl., Enum. Pl. Jav. 60 (1827)-non Alpinia bracteata Roxb. $(1811,1820)$ nec Alpinia bracteata Rosc. (1814).

Alpinia blumei K. Schum. in Bot. Jahrb. 27: 282 (1899) \& Pflanzenr. Zing. 324 (1904)—non A. blumei Dietr. (1839).

Since it was Schumann's intention to honour Carl Ludwig Blume, and since the existence of $A$. carolinensis disallows the adoption of Blume's first Christian name as the new epithet, the great Dutch botanist's second given name is taken up for this species.

A. ludwigiana is imperfectly known, but the type material shows a plant with large bracts and the remnants of slender corolla tubes. For these reasons the species has been placed in Alpinia sect. Guillainia (Smith, 1975: 156).

Alpinia bodenii R. M. Smith, nom. nov. Fig. 9C.

Type: Irian Jaya; Mt Carstenz expedition, 1912-13, camp VIa, 1300m, Boden Kloss s.n. (BM, K).

Syn.: Eriolopha sericea Ridley in Trans. Linn. Soc. Bot. 9: 221 (1916)non Alpinia sericea Ridley (1914).

A. bodenii belongs to sect. Dieramalpinia.

Alpinia elmeri R. M. Smith, nom. nov.

Syntypes: Philippines; Luzon, Mt Bulusan, v 1916, Elmer 16167; ibidem, viii 1916, Elmer 16954 (BM, L, U, US).

Syn.: Alpinia longipetiolata Elmer in Lflts Philipp. Bot. 8: 2969

(1919) — non A. longipetiolata Gagnep. (1906).

The BM type material of $A$. elmeri is poor, but the description of the flowers, in particular the quadrate labellum, indicate that the species belongs to sect. Alpinia subsect. Presleia.

\section{New COMBINATIONS in Alpinia}

Alpinia albipurpurea (Van Royen) R. M. Smith, comb. nov.

Basionym: Kolowratia albipurpurea Van Royen, Alpine Flora of New Guinea 2: 890, f.298 (1979).

Type: Papua New Guinea; Piundaunde valley, van Balgooy 583 (L).

A. albipurpurea belongs to the clearly defined sect. Pycnanthus subsect. Pycnanthus which is well characterized by the subapically dentate filament and strap-shaped to oblong labellum.

Amongst the specimens cited by van Royen several have been previously referred to $A$. sp. agg. aff. singuliftora R. M. Smith in Notes RBG Edinb. 36: 281 (1978). These are LAE 54650 (LAE); NGF 39753 (LAE); NGF 40216 (LAE, E); NGF 55850 (LAE, E); NGF 39517 (LAE); NGF 29995 (LAE). Van Royen has also cited LAE 50267 (the 
type number of $A$. hageana R. M. Smith - holo. E, iso. LAE) under A. albipurpurea, presumably in error for LAE 50266.

Alpinia corneri (Holttum) R. M. Smith, comb. nov.

Basionym: Cenolophon corneri Holttum in Gard. Bull. Sing. 13: 139 (1950).

Type: W Malaysia, Trengganu, Kemaman, B Kajang, Corner SFN 30506 (SING, K, E).

The reasons for not accepting Cenolophon Bl. at generic level have been discussed elsewhere (Smith, 1982: 69).

Alpinia gigantifolia (Elmer) R. M. Smith, comb. nov.

Basionym: Zingiber gigantifolia Elmer, Lflts Philipp. Bot. 8: 2916 (1918).

Syntypes: Philippines, Luzon, prov. Sorsogon, Mt Bulusan, v 1916, Elmer 14603 (n.v.); ibidem, Elmer 16154 (n.v.).

Syn.: Adelmeria gigantifolia (Elmer) Elmer, op. cit. 2963.

The sectional position of $A$.gigantifolia is problematic. A further collection, Elmer $16153(\mathrm{~K})$ shows large bracts and slightly elongate fruit. It is tentatively placed in sect. Dieramalpinia.

Alpinia juliformis (Ridley) R. M. Smith, comb. nov.

Basionym: Eriolopha juliformis Ridley in Trans. Linn. Soc. Bot. 9: 219 (1916).

Type: Irian Jaya, Mt Carstenz expedition, 1912-1913, Boden Kloss s.n. (BM, K).

Alpinia klossii (Ridley) R. M. Smith, comb. nov.

Basionym: Eriolopha klossii Ridley in Trans. Linn. Soc. Bot. 9: 220 (1916).

Type: Irian Jaya, Mt Carstenz expedition, 1912-1913, Boden Kloss s.n. (BM, K).

Both $A$. juliformis and A. klossii are placed in sect. Dieramalpinia.

\section{New COmbinations in Genera other than Alpinia}

Riedelia cordylinoides (Ridley) R. M. Smith, comb. nov.

Basionym: Alpinia cordylinoides Ridley in Trans. Linn. Soc. Bot. 9: 211 (1916).

Type: Irian Jaya; Mt Carstenz expedition, Boden Kloss s.n. (BM).

$R$. cordylinoides belongs to the large Riedelia sect. Schefferia. 


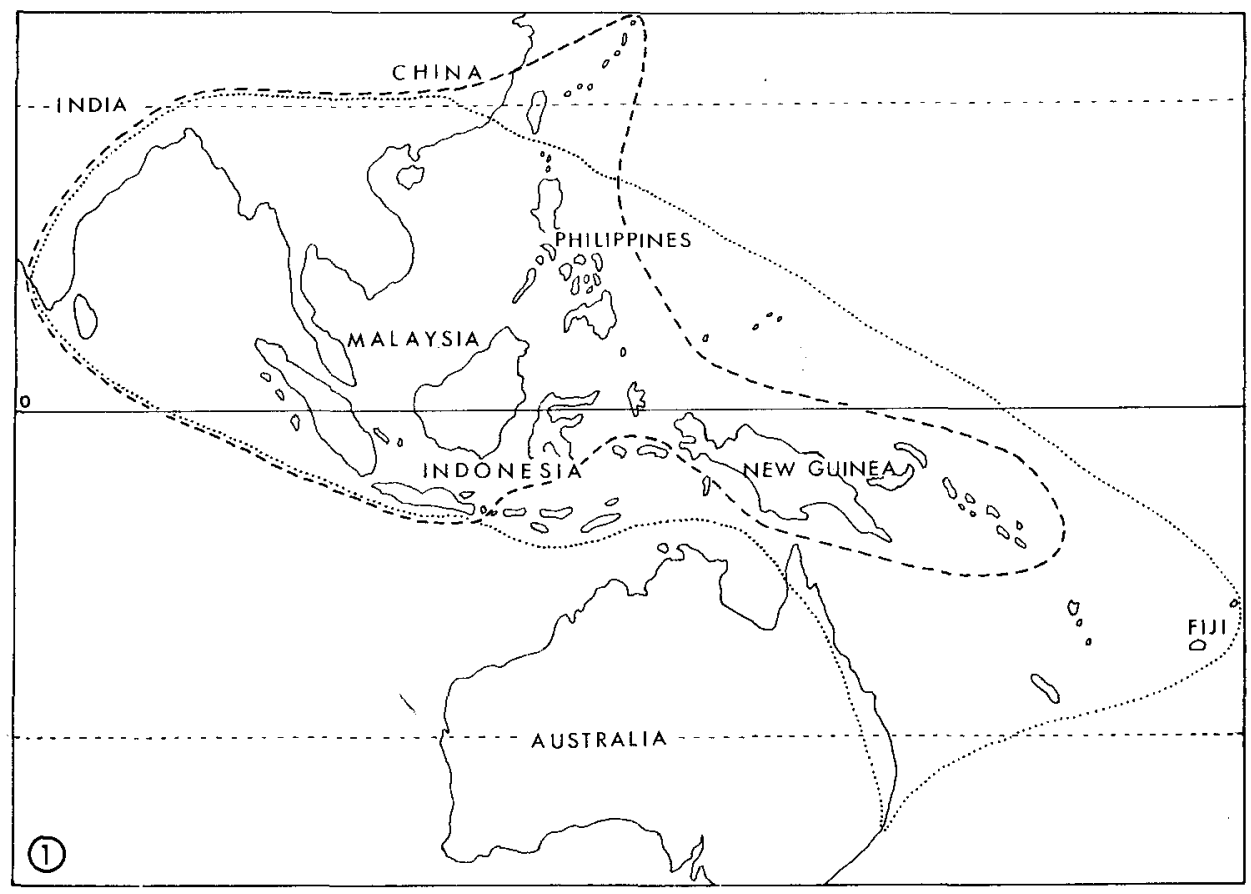

MAP 1. Alpinia Roxb. (K. Schumann, 1904-errors made by him with regard to the structure of the bracteoles have been corrected). Subgenus Alpinia (including subgenera Catimbium, Probolocalyx \& Rhizalpinia p.p.) ----; Subgenus Dieramalpinia ...

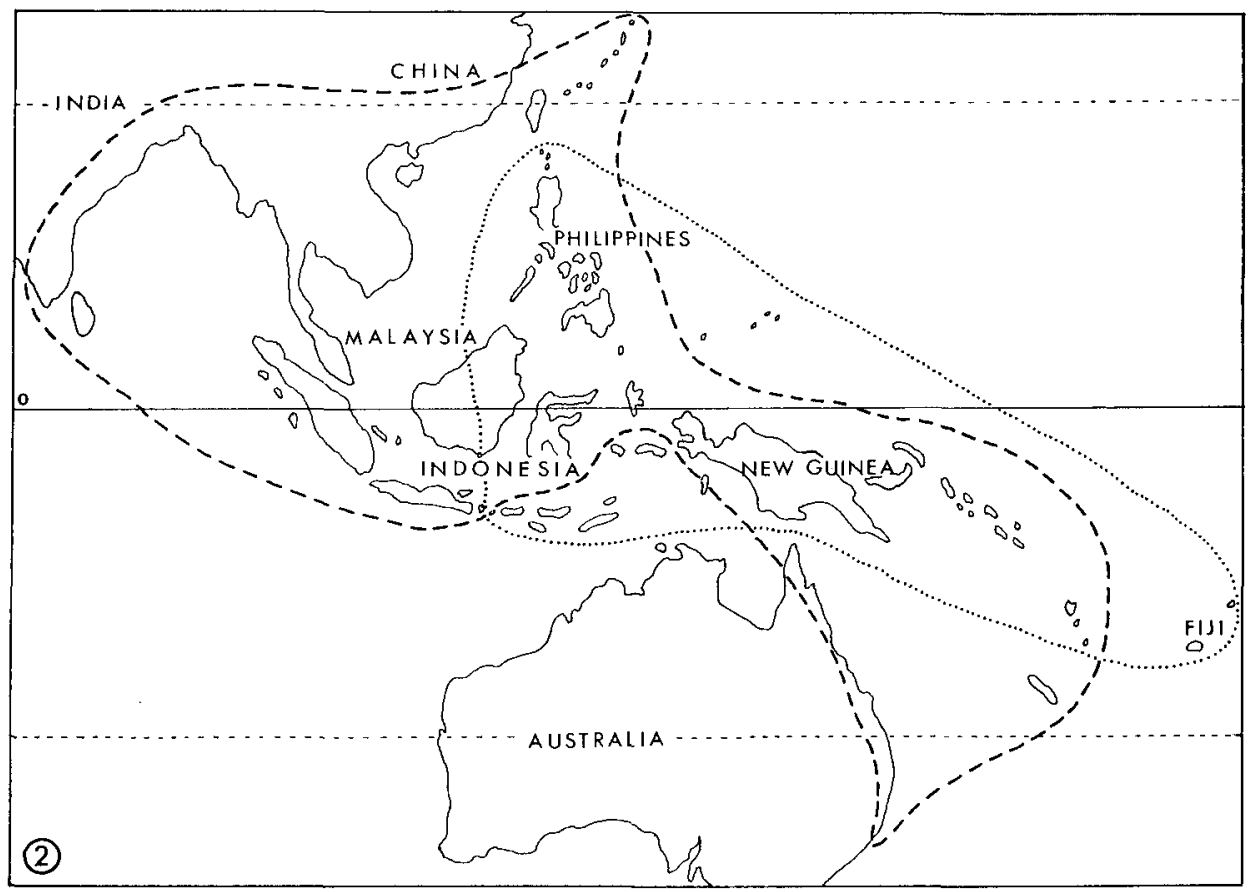

MAP 2. Alpinia Roxb. (R. M. Smith, 1990). Subgenus Alpinia----; Subgenus 


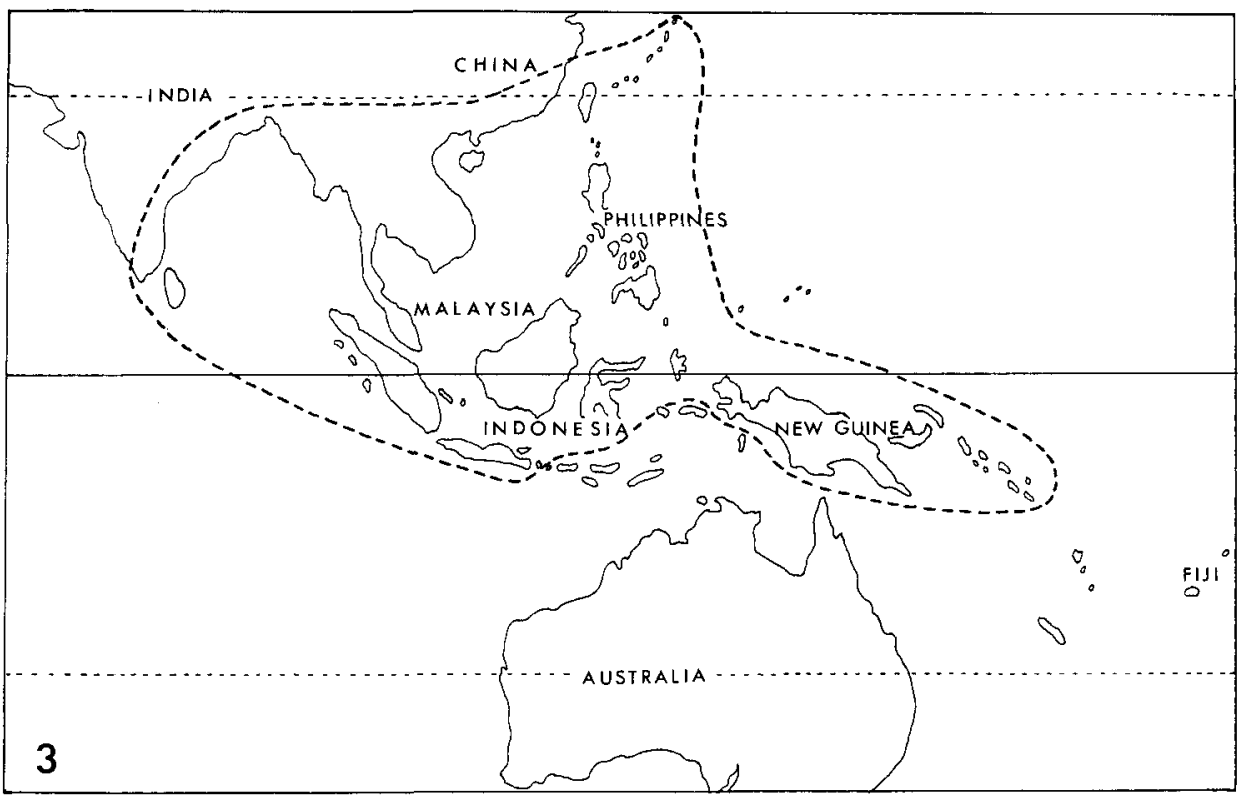

MAP 3. Subgen. Alpinia sect. Alpinia

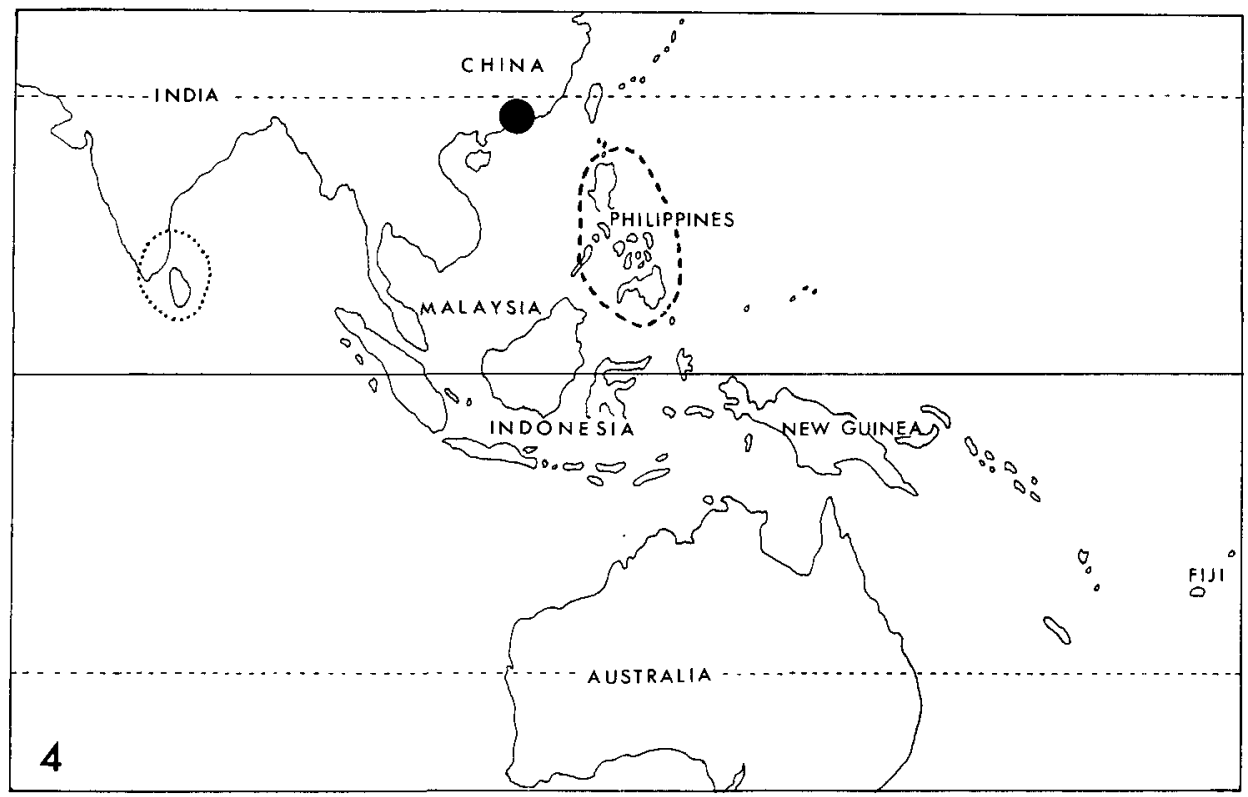

Map 4. Subgen. Alpinia sect. Didymanthus - Subgen. Alpinia sect. Kolowratia ---- ; Subgen. Alpinia sect. Fax ... 


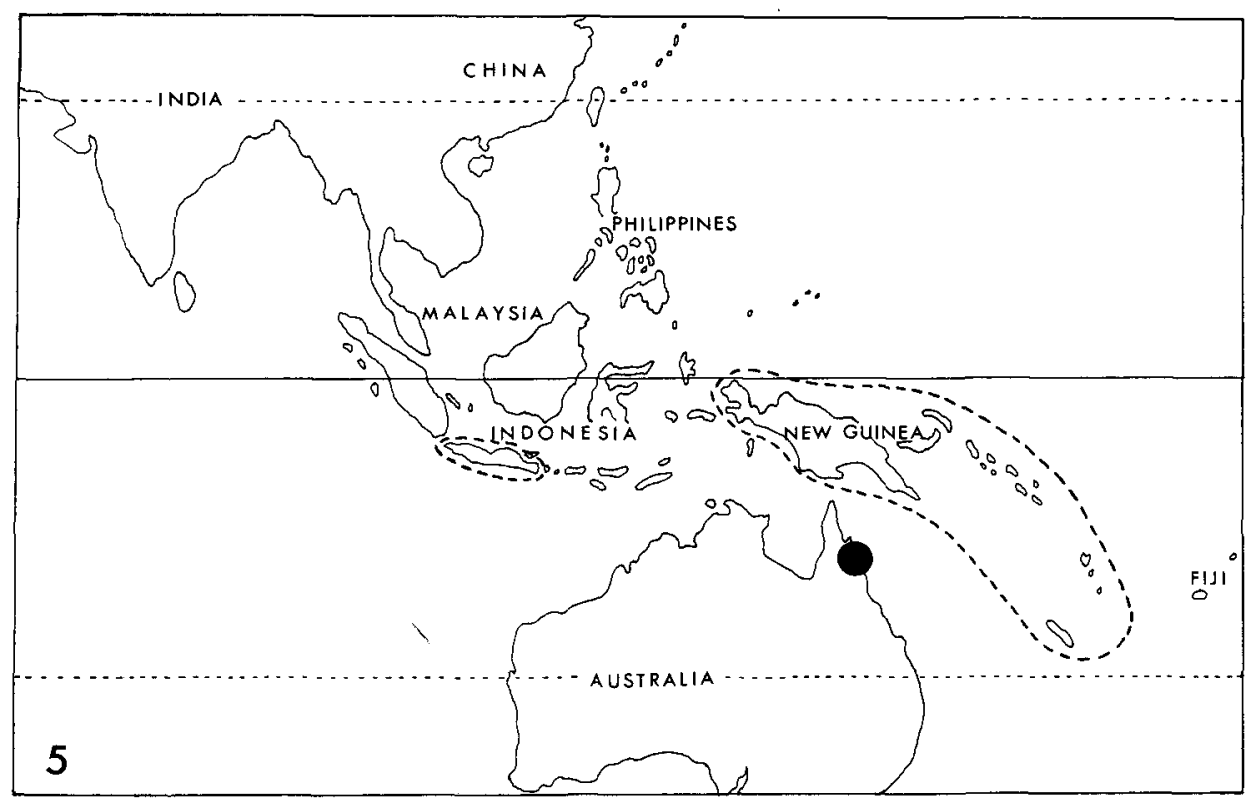

MAP 5. Subgen. Alpinia sect. Guillainia----; Subgen. Alpinia sect. Arctiflorae

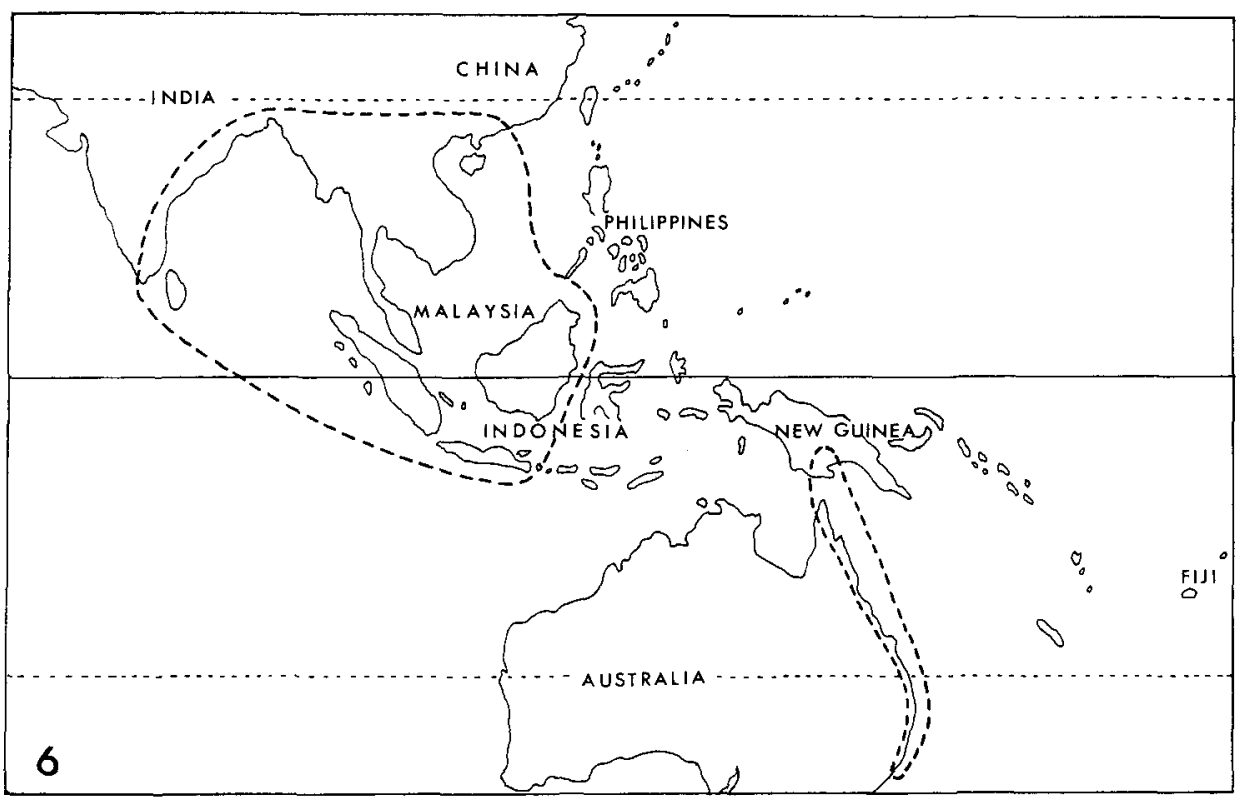

MAP 6. Subgen. Alpinia sect. Allughas----. 


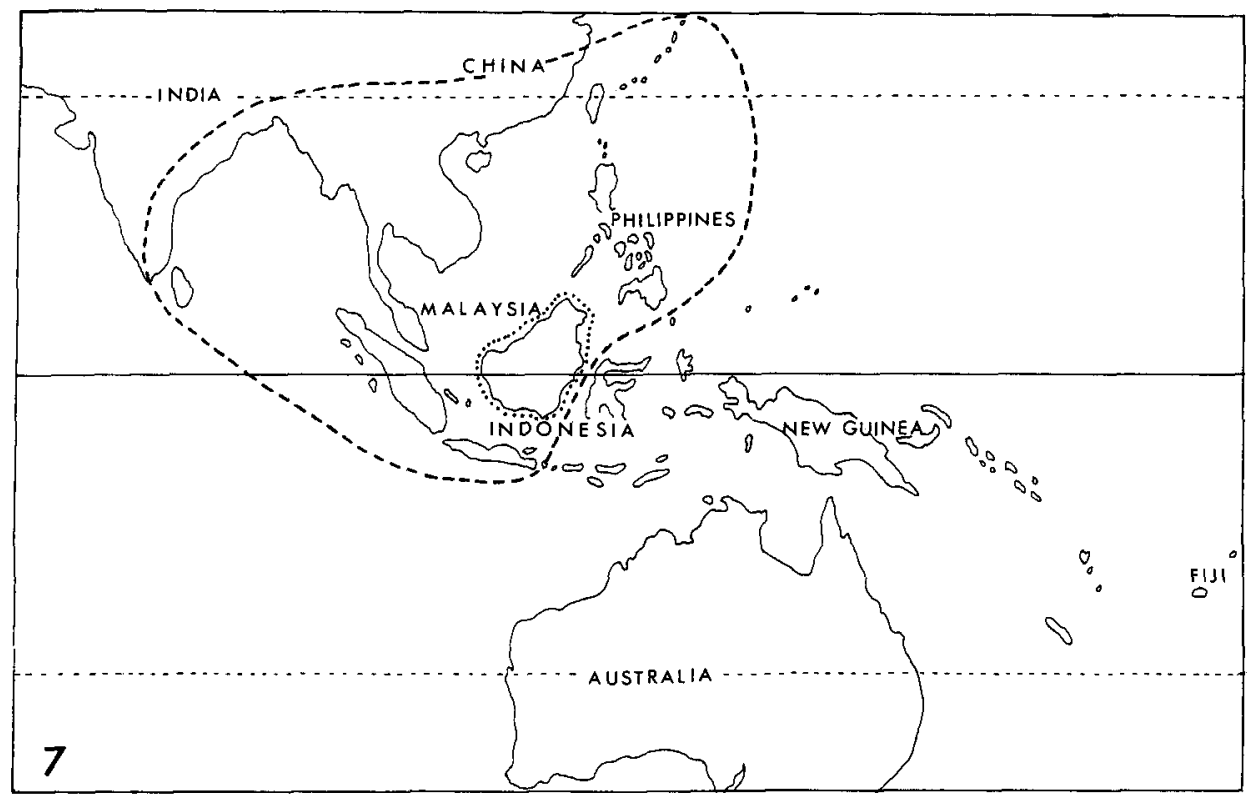

MAP 7. Sect. Alpinia subsect. Alpinia----; Sect. Alpinia subsect.

Paniculatae...

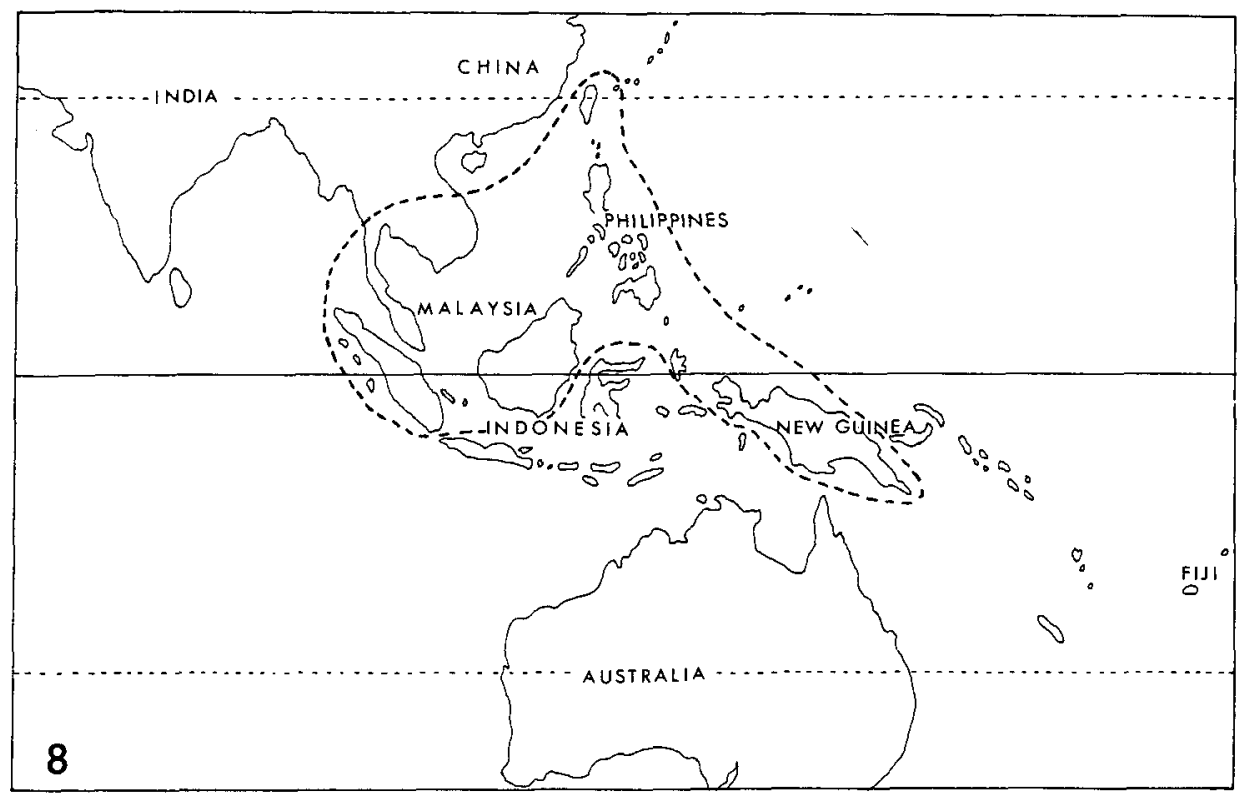

MAP 8. Sect. Alpinia subsect. Presleia---- 


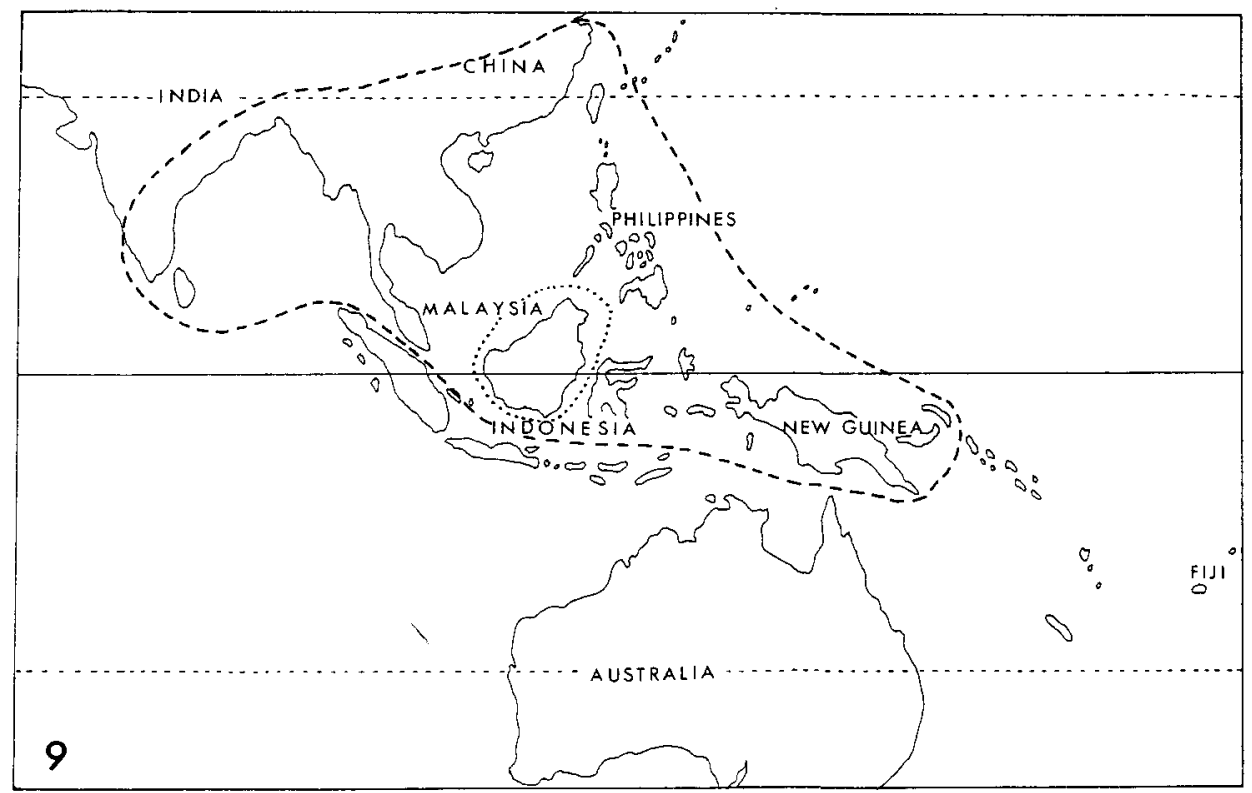

MAP 9. Sect. Alpinia subsect. Catimbium----; Sect. Alpinia subsect.

Probolocalyx ...

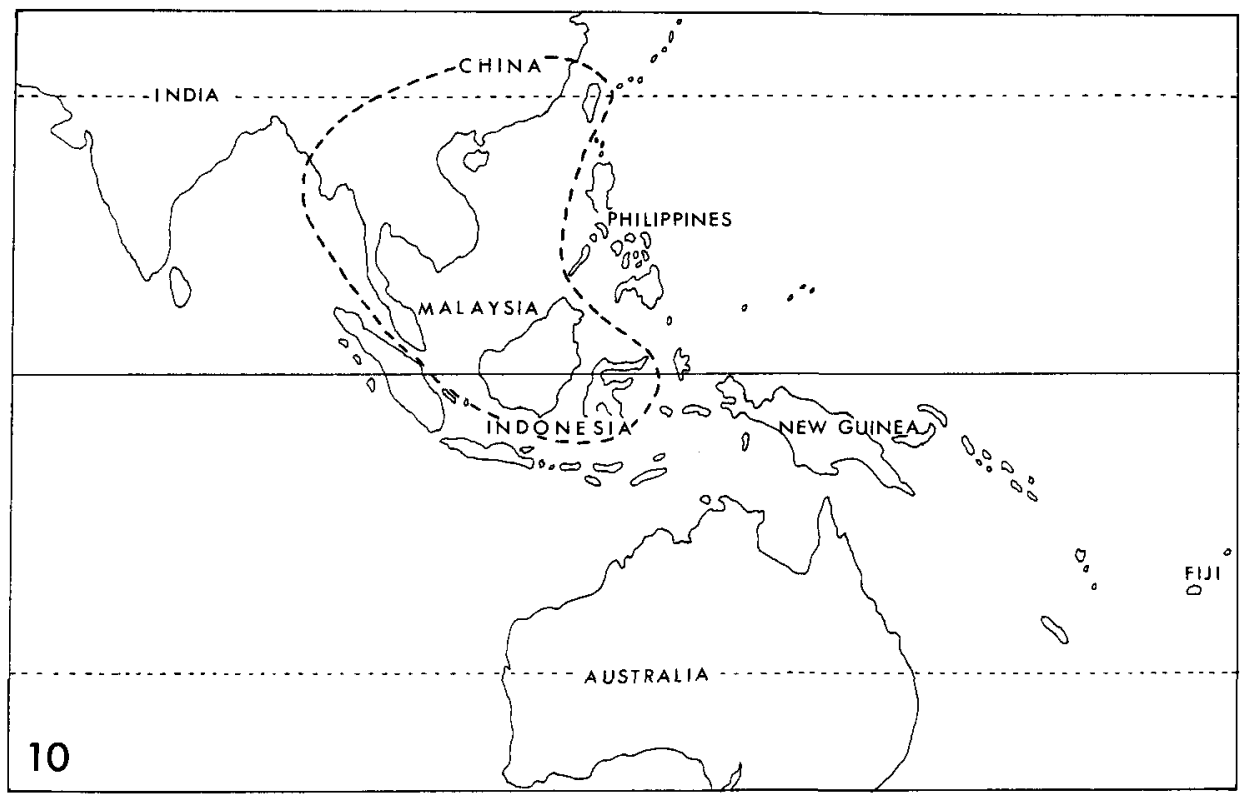

MaP 10. Sect. Alpinia subsect. Cenolophon----. 


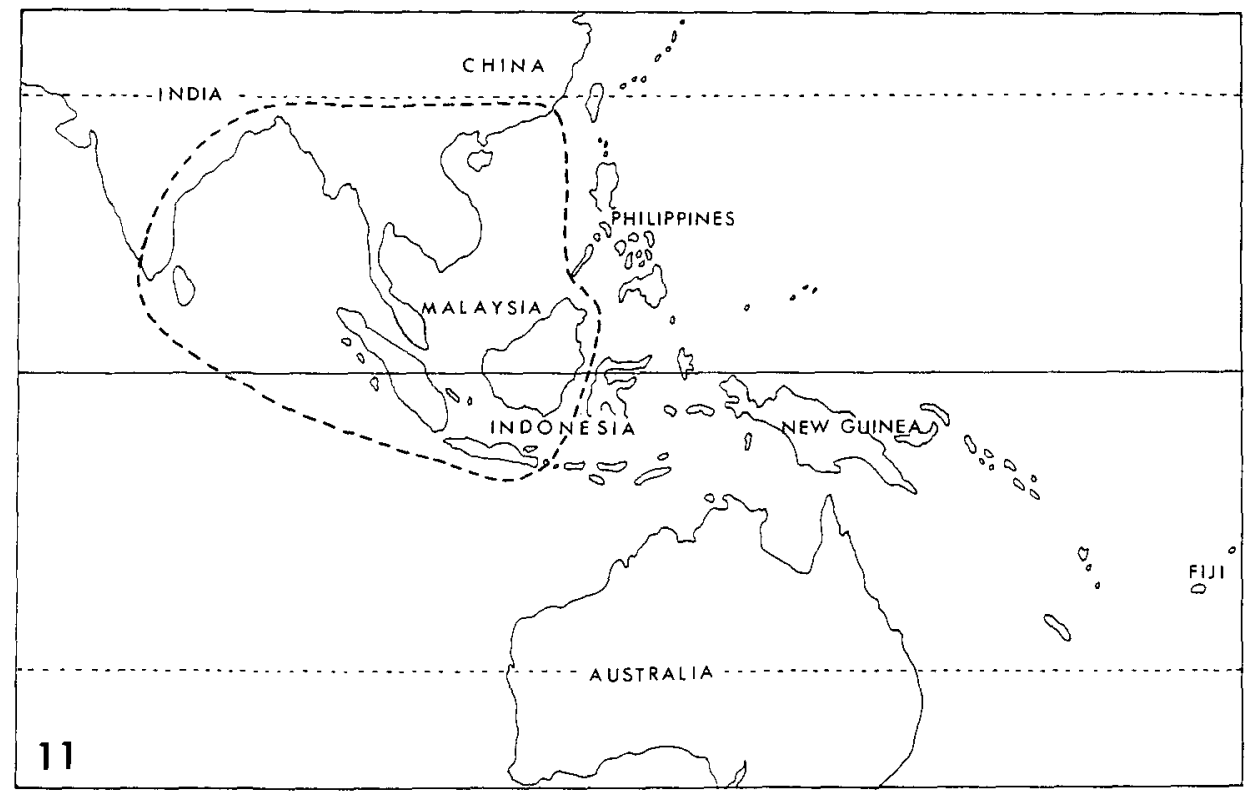

MAP 11. Sect. Allughas subsect. Allughas ...

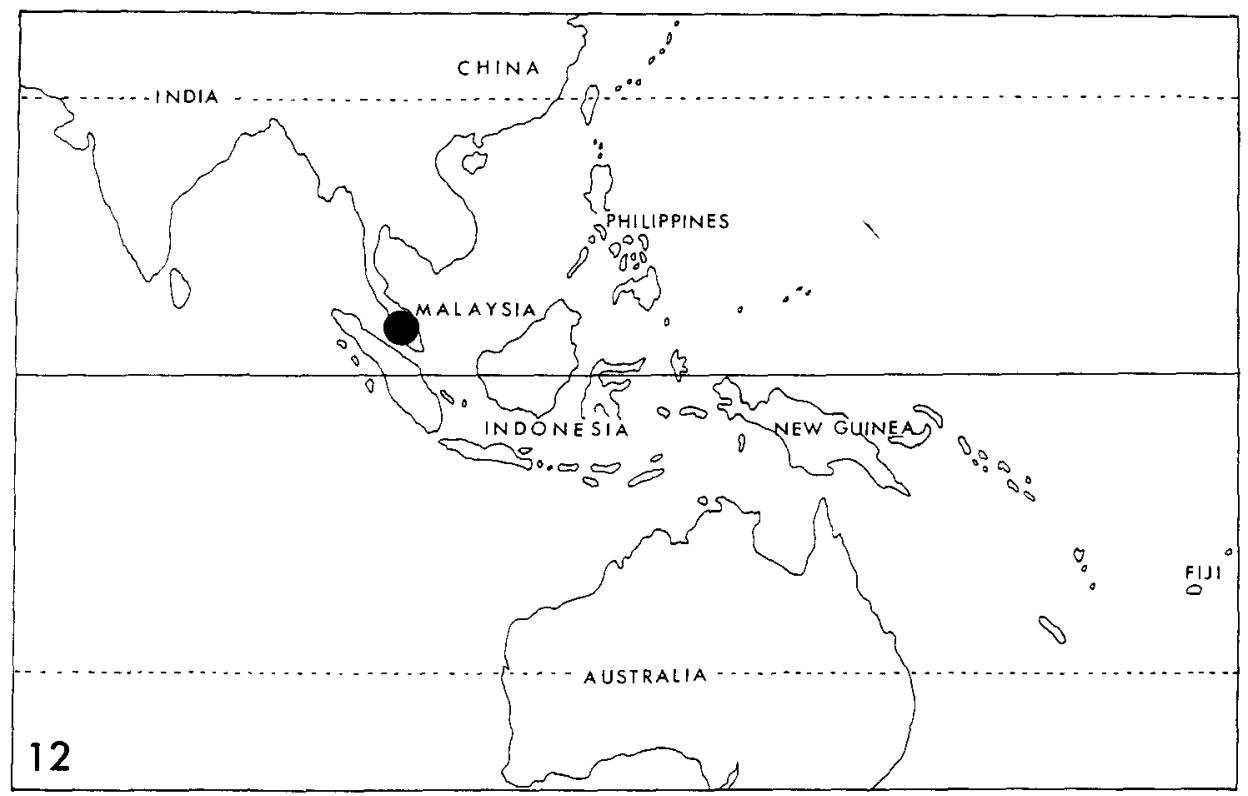

MAP 12. Sect. Allughas subsect. Odontychium 


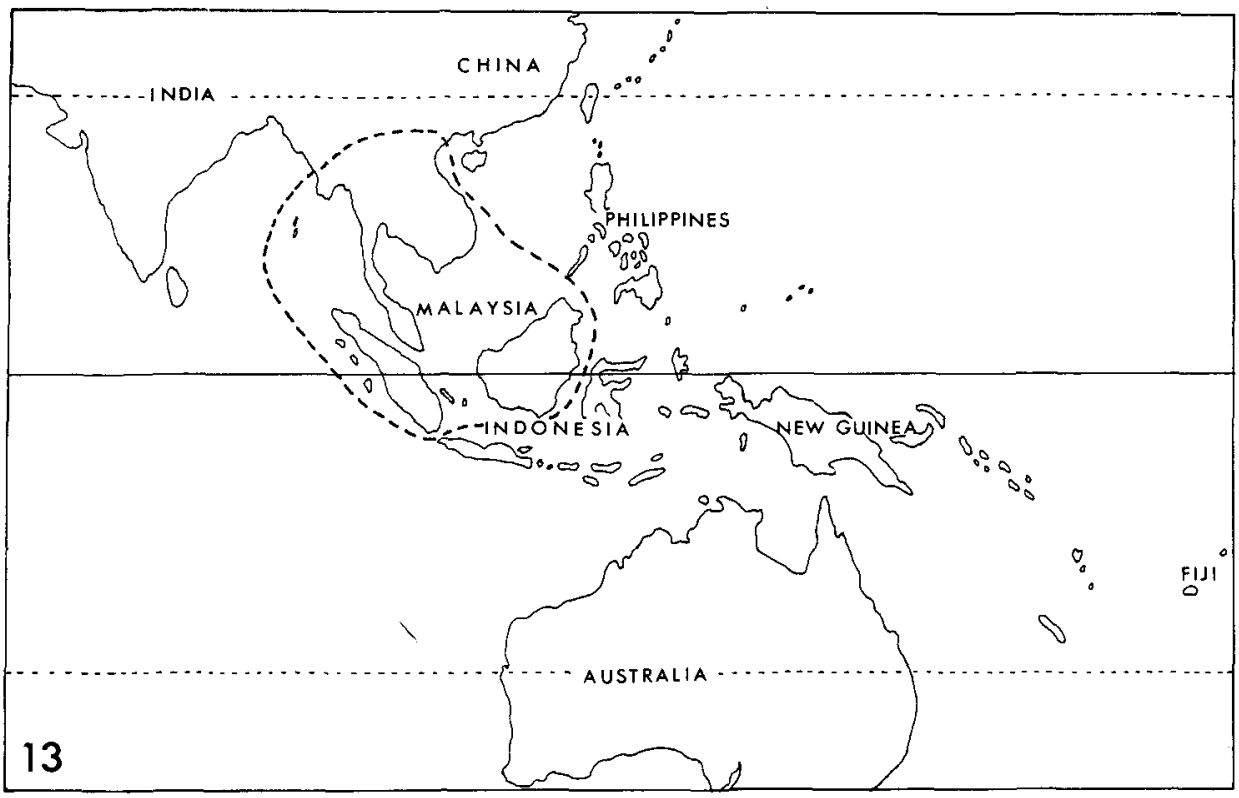

MAP 13. Sect. Allughas subsect. Strobidia----.

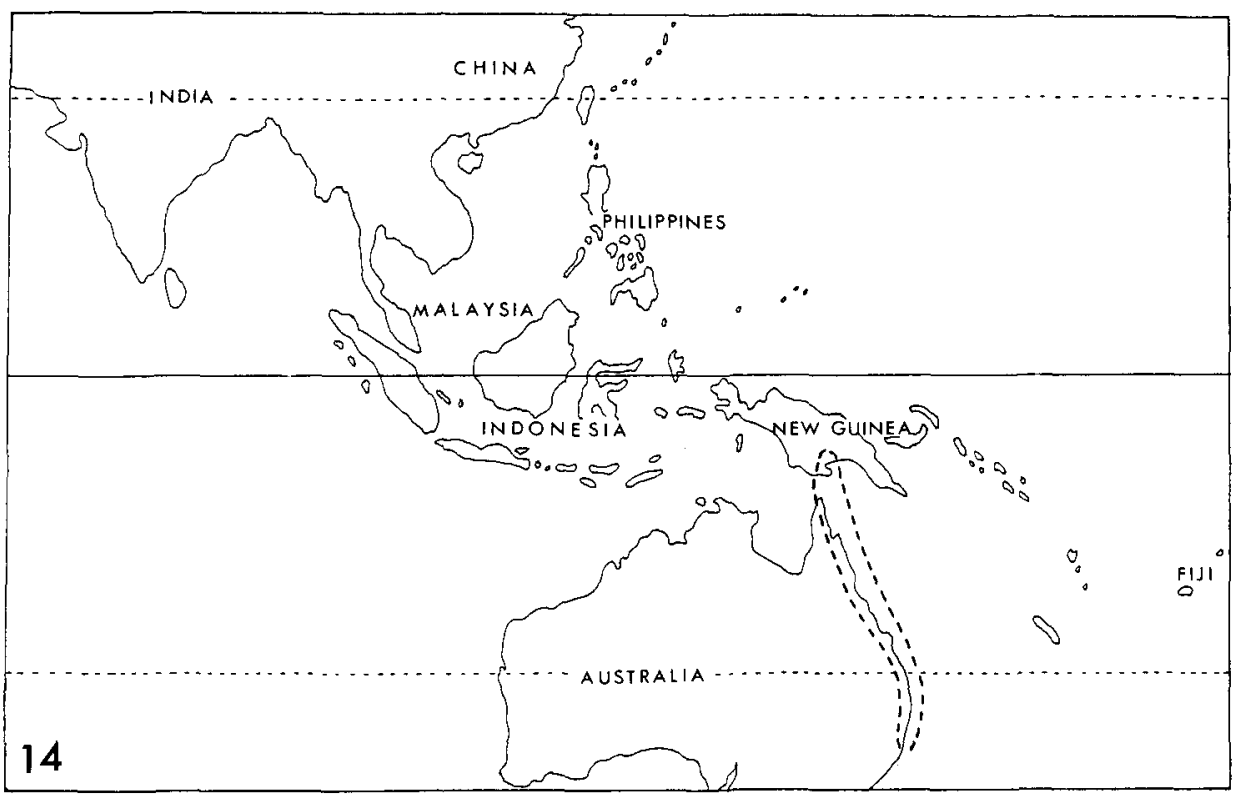

MAP 14. Sect. Allughas subsect. Caerulea----. 


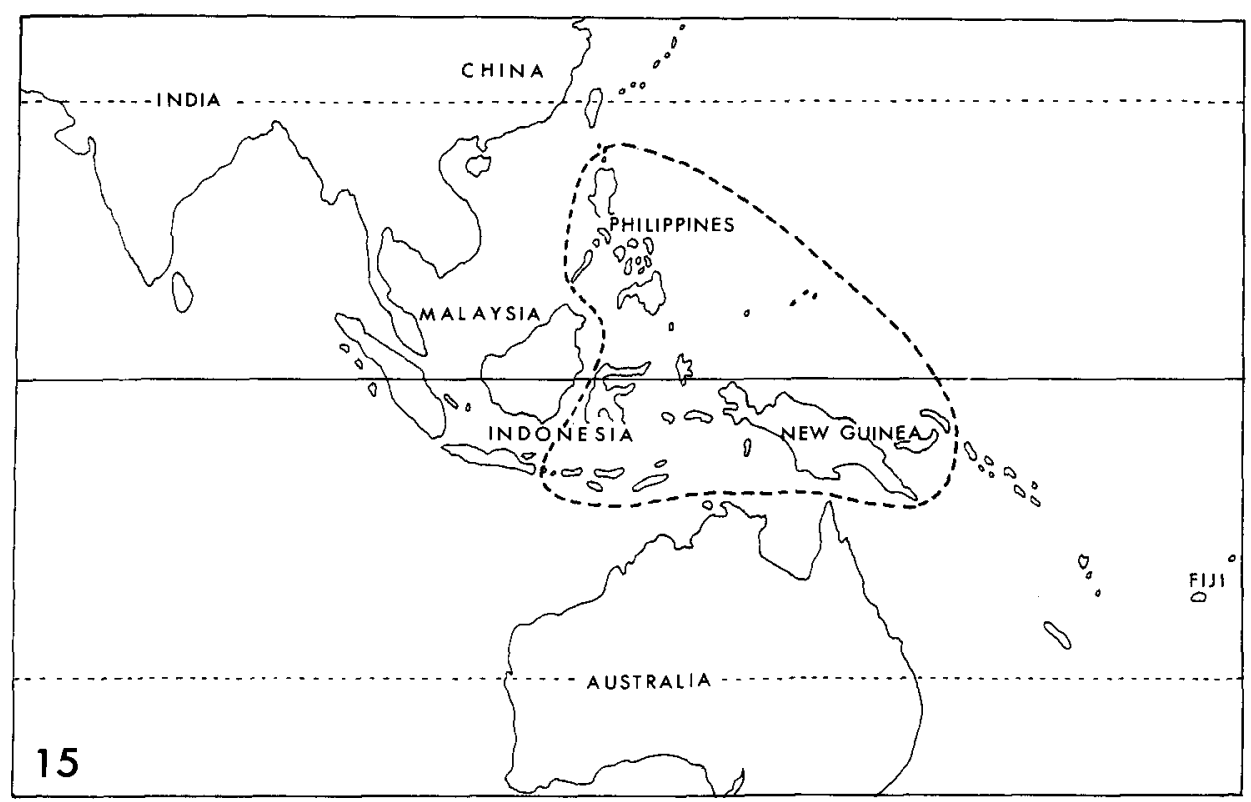

MAP 15. Subgen. Dieramalpinia sect. Dieramalpinia---- .

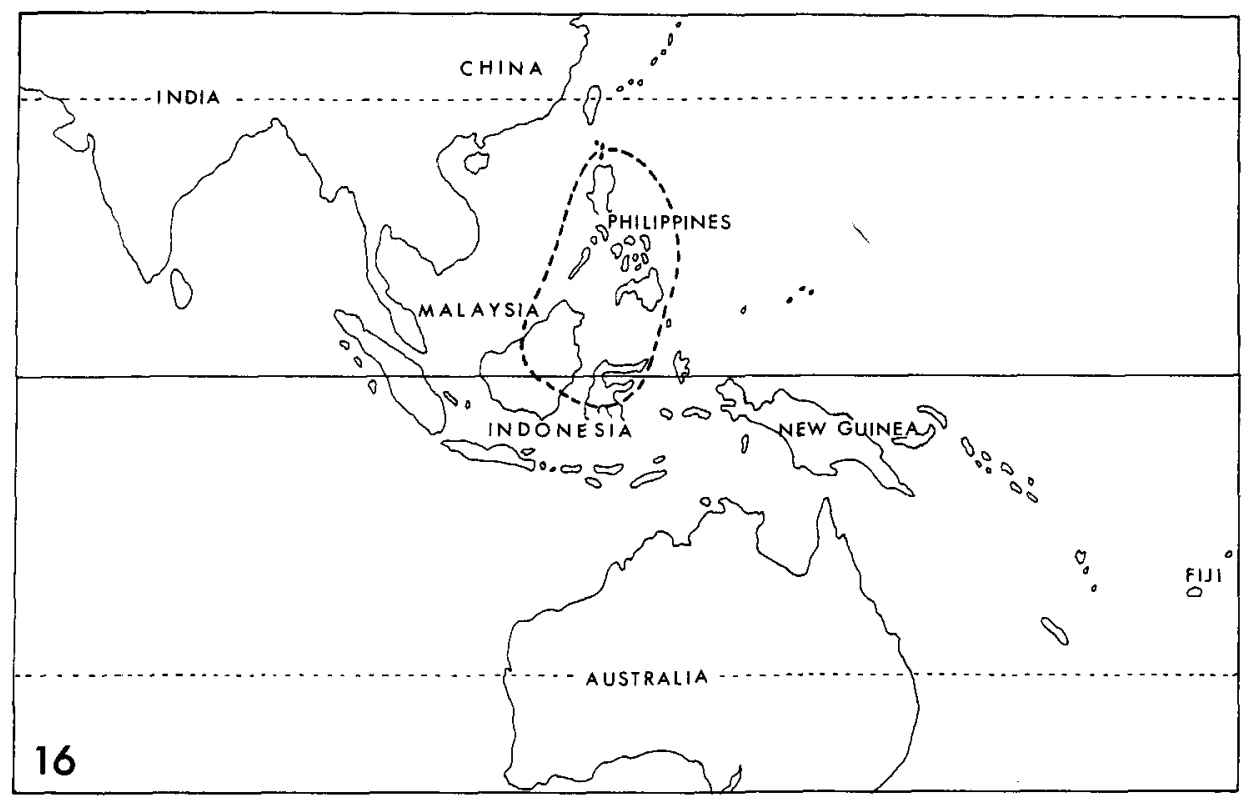

MAP 16. Subgen. Dieramalpinia sect. Eubractea---- . 


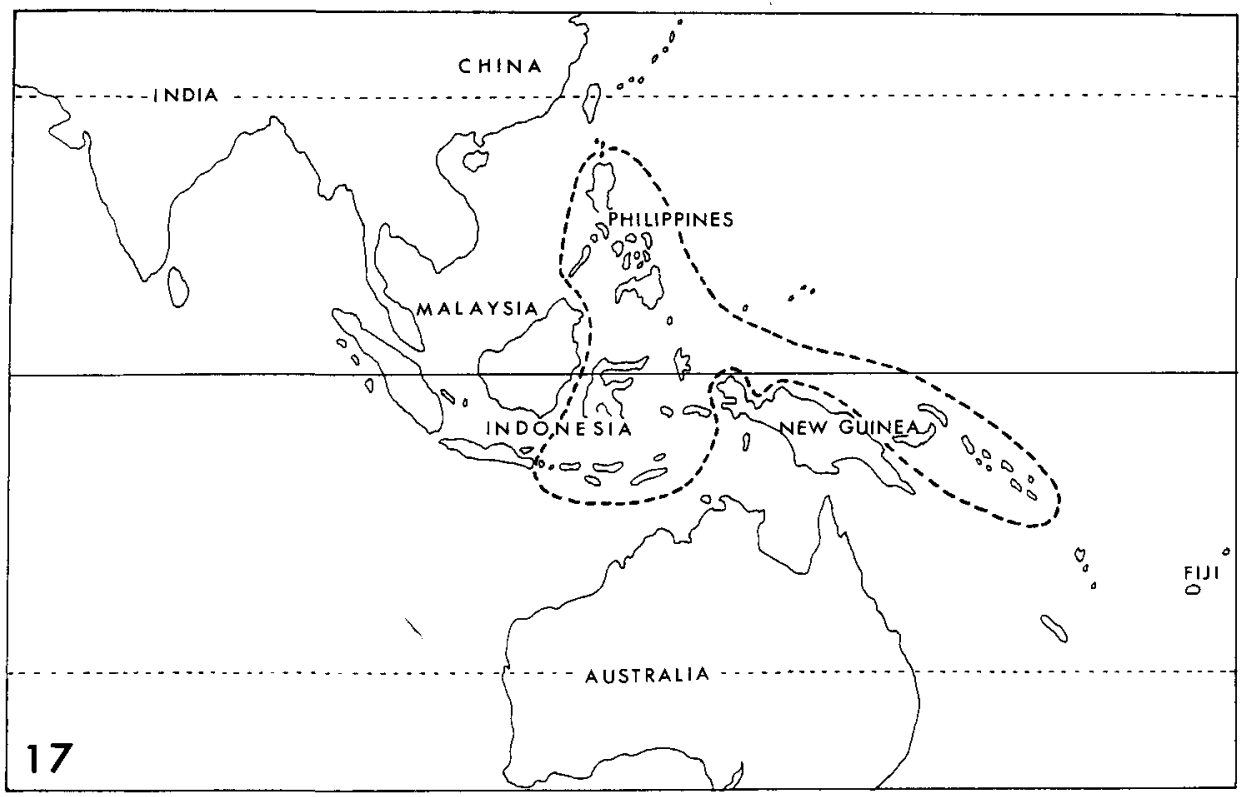

MAP 17. Subgen. Dieramalpinia sect. Myriocrater----.

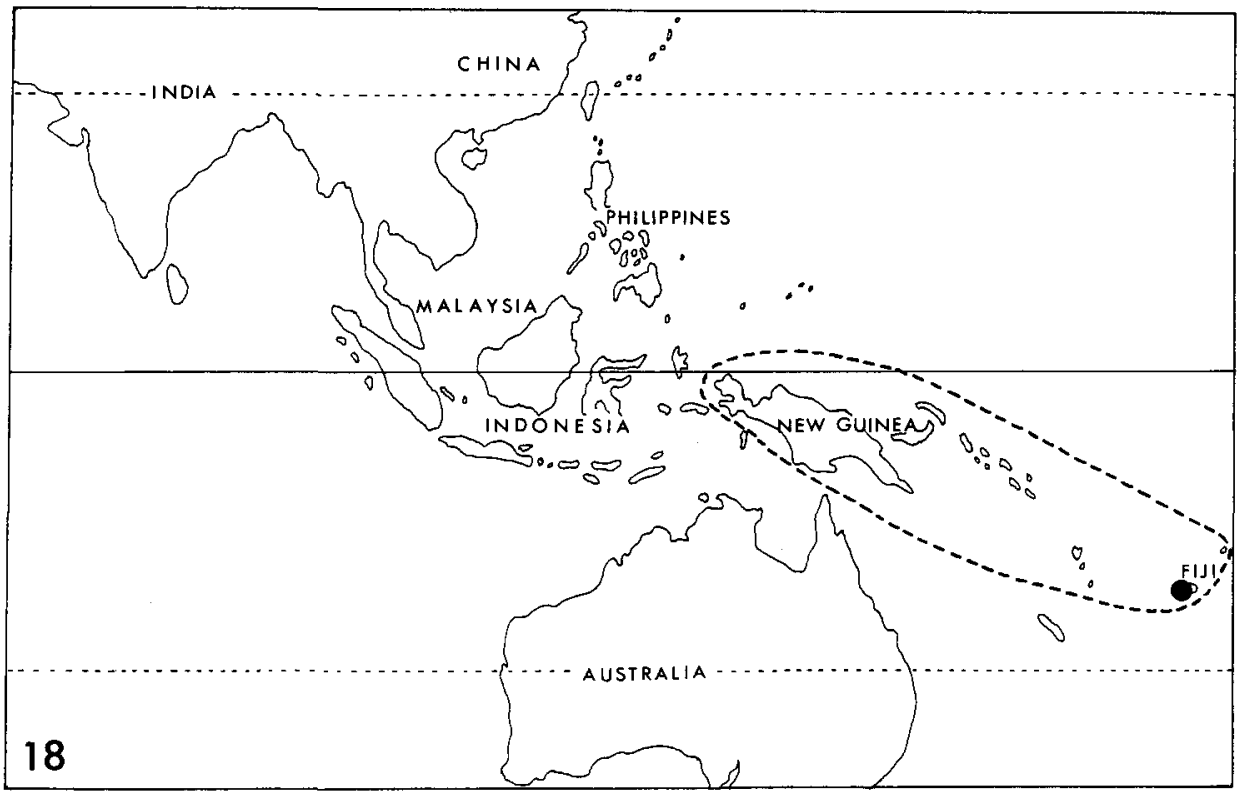

MaP 18. Subgen. Dieramalpinia sect. Pycnanthus: subsect.

Pycnanthus----; subsect. Amomiceps 


\section{ACKNOWLEDGEMENTS}

I am deeply indebted to $\mathrm{Mr} \mathrm{B}$. L. Burtt for encouragement and advice during the preparation of this paper. Thanks are also due to the directors of the following institutions for the loan of herbarium material (BM, K, L, UC, US, W).

\section{REFERENCES}

BurtT, B. L. \& SMith, R. M. (1972a). Key species in the taxonomic history of Zingiberaceae. Notes from the Royal Botanic Garden Edinburgh 31: 177-227.

_- (1972b). Notes on Malesian Zingiberaceae. Op. cit. 307-316.

(1972c). Monoecism in Alpinia. Op. cit. 32: 29-43.

(1975). The Rediscovery of Cenolophon rubrum. Op. cit. 34: 107-112.

(1983). Zingiberaceae. In Dasssanyake, M. D. (ed.). Revised Handbook of the Flora of Ceylon 488-532.

Hayata, B. (1915). Scitamineae. Icones Plantarum Formosanarum 5: 213-228.

_- (1920). Scitamineae. Op. cit. 9: 118-124.

Holttum, R. E. (1950). The Zingiberaceae of the Malay Peninsula. Gardens Bulletin Singapore 13: 1-248.

Lofsener, T. (1930). Zingiberaceae. Die Natürlichen Pflanzenfamilien 2, 15A: 611624.

Merrill, E. D. (1922). Zingiberaceae. Enumeration of Philippine Plants 228-247.

Ridley, H. N. (1909). The Scitamineae of the Philippine Islands. Philippine Journal of Science 4: 155-199.

Schumann, K. (1904). Zingiberaceae. In Engler, A. (ed.) Das Pflanzenreich 20. Berlin.

Smith, R. M. (1975). A preliminary review of the large bracteate species of Alpinia. Notes from the Royal Botanic Garden Edinburgh 34: 149-182.

—- (1977). Additional notes on Alpinia sect. Myriocrater. Op. cit. 35: 195-208.

(1978). Alpinia sect. Pycnanthus and its New Guinea species. Op. cit. 36: 273292.

(1980). A new genus of Zingiberaceae from N Burma. Op. cit. 38: 13-17.

- (1982). Systematic notes on, and new species of, Zingiberaceae of the G. Mulu National Park. Botanical Journal of the Linnean Society 85: 36-73.

(1989). A new Alpinia from Sabah. Notes from the Royal Botanic Garden Edinburgh 45: 341-343.

Trimen, H. (1898). Scitamineae. Handbook of the Flora of Ceylon 4: 238-265.

Valeton, T. (1913). Zingiberaceae. Nova Guinea (Botanique) 8: 923988.

- (1914). Die Zingiberaceen Deutsch-Neu-Guinea. Botanische Jahrbücher für Systematik Pflanzengeschichte und Pflanzengeographie 52: 40-100.

Wu, TE-LiN (1981). Zingiberaceae. Flora Reipublicae Popularis Sinicae 16: 26-153. 